\title{
MIOCENE FLORAS IN THE LOWER RHENISH BASIN AND THEIR ECOLOGICAL INTERPRETATION
}

\author{
J. VAN DER BURGH \\ Laboratory of Palaeobotany and Palynology, Heidelberglaan 2, 3508 TC Utrecht (The Netherlands)
}

(Received May 6, 1986; revised and accepted November 10, 1986)

\begin{abstract}
Van der Burgh, J., 1987. Miocene floras in the lower Rhenish Basin and their ecological interpretation. Rev. Palaeobot. Palynol., 52: 299-366.

Some 29 samples containing fruits and seeds were collected in three open cast mines in the lower Rhenish Basin. They all originate from Upper Miocene deposits. The samples were analysed for their fruit and seed contents and these are described shortly. Four new species: Erica palaeoarborea, Vaccinium miocenicum, Rhynchospora tertiaria and Potamogeton extremitatus are formally described. The floras are interpreted ecologically using the ecological comparison table method and a reconstruction of the landscape is presented.
\end{abstract}

\section{Introduction}

In the course of the years 1978 to 1983 several samples of sediment containing fruits and seeds were collected in the open cast mines of the "Rheinbraun" at Eschweiler, Hambach and Bedburg. They originate from sands, silts, clays and lignite. The samples from the open cast mine "Zukunft West" at Eschweiler contain, besides material from the "Indener Schichten", floras from the fluviatile equivalent of the marine "Neurather Sand". The samples from the open cast mines "Hambach" near Düren and "Fortuna" near Bedburg contain only material from the "Indener Schichten". In this paper the ecology of the known flora of Upper Miocene deposits is presented. Therefore, some samples of autochthonous floras, to be described in another paper (Van der Burgh, in press), are discussed.

\section{Material}

The following samples have been used for this study (Table I):

\section{Eschweiler}

Two samples, nos.7807 and 7809, were collected in 1974 from a thin lignite seam, mostly very impure, partly developed as no more than a lignitic clay. It lies on top of coarse fluviatile sands and is covered by a series of fine sands and clays, which in turn are covered by the "Garzweiler" seam. The whole series is the counterpart of the marine "Neurather Sand" in other quarries in the same region. Sample 7807 originates from a lignite, sample 7809 from a clay. Samples 7807, 14399, 14400 and 14402 were collected from the "Garzweiler" lignitic seam, which is a thin (maximum thickness $3 \mathrm{~m}$ ) 
TABLE I

List of samples

\begin{tabular}{|c|c|c|c|c|}
\hline Number & $\begin{array}{l}\text { Coordinates } \\
\text { Eschweiler }\end{array}$ & $\begin{array}{l}\text { Height above } \\
\text { sea level } \\
\text { (m) }\end{array}$ & $\begin{array}{l}\text { Range of seed } \\
\text { size } \\
(\mathrm{mm})\end{array}$ & $\begin{array}{l}\text { Year of } \\
\text { collection }\end{array}$ \\
\hline 7807 & & & $1-33$ & 1974 \\
\hline 7808 & $35^{\circ} 84^{\prime} \mathrm{N} 18^{\circ} 42^{\prime} \mathrm{E}$ & 88 & $1-10$ & 1975 \\
\hline 7809 & & & $2 \cdots 35$ & 1975 \\
\hline 8297 & $36^{\circ} 64^{\prime} \mathrm{N} 19^{\circ} 80^{\prime} \mathrm{E}$ & 64 & $1-11$ & 1979 \\
\hline 8300 & $36^{\circ} 20^{\prime} \mathrm{N} 19^{\circ} 69^{\prime} \mathrm{E}$ & 90 & $1-11$ & 1979 \\
\hline 8334 & $36^{\circ} 20^{\prime} \mathrm{N} 19^{\circ} 69^{\prime} \mathrm{E}$ & 92 & $1-8$ & 1979 \\
\hline 8335 & $36^{\circ} 24^{\prime} \mathrm{N} 19^{\circ} 69^{\prime} \mathrm{E}$ & 85 & $1-7$ & 1979 \\
\hline 8336 & $36^{\circ} 69^{\prime} \mathrm{N} 19^{\circ} 56^{\prime} \mathrm{E}$ & 65 & 125 & 1979 \\
\hline 13285 & $35^{\circ} 19^{\prime} \mathrm{N} 19^{\circ} 69^{\prime} \mathrm{E}$ & 109 & 121 & 1981 \\
\hline 13286 & $36^{\circ} 70^{\prime} \mathrm{N} 19^{\circ} 56^{\prime} \mathrm{E}$ & 66 & $1-15$ & 1979 \\
\hline 14399 & $35^{\circ} 84^{\prime} \mathrm{N} 18^{\circ} 42^{\prime} \mathrm{E}$ & 88 & $1 \cdots 15$ & 1975 \\
\hline 14400 & $35^{\circ} 84^{\prime} \mathrm{N} 18^{\circ} 42^{\prime} \mathrm{E}$ & 88 & $1 \cdot 15$ & 1975 \\
\hline 14401 & $35^{\circ} 72^{\prime} \mathrm{N} 20^{\circ} 17^{\prime} \mathrm{E}$ & 67 & $1-80$ & 1981 \\
\hline 14402 & $35^{\circ} 84^{\prime} \mathrm{N} 18^{\circ} 42^{\prime} \mathrm{E}$ & 89 & $1-33$ & 1975 \\
\hline 14403 & $\begin{array}{l}36^{\circ} 58^{\prime} \mathrm{N} 19^{\circ} 72^{\prime} \mathrm{E} \\
\text { Fortuna }\end{array}$ & 60 & $2-6$ & 1979 \\
\hline 8295 & $51^{\circ} 84^{\prime} \mathrm{N} 42^{\circ} 36^{\prime} \mathrm{E}$ & 22 & $1-40$ & 1980 \\
\hline 8699 & $52^{\circ} 29^{\prime} \mathrm{N} 42^{\circ} 61^{\prime} \mathrm{E}$ & 26 & $2-40$ & 1981 \\
\hline 8700 & $\begin{array}{l}52^{\circ} 29^{\prime} \mathrm{N} 42^{\circ} 61^{\prime} \mathrm{E} \\
\text { Hambach }\end{array}$ & 26 & $1-21$ & 1981 \\
\hline 13349 & $40^{\circ} 53^{\prime} \mathrm{N} 33^{\circ} 70^{\prime} \mathrm{E}$ & 29 & 1.15 & 1982 \\
\hline 14139 & $39^{\circ} 83^{\prime} \mathrm{N} 34^{\circ} 90^{\prime} \mathrm{E}$ & 20 & 270 & 1983 \\
\hline 14140 & $41^{\circ} 73^{\prime} \mathrm{N} 32^{\circ} 34^{\prime} \mathrm{E}$ & 0 & $1-80$ & 1983 \\
\hline 14141 & $39^{\circ} 77^{\prime} \mathrm{N} 34^{\circ} 35^{\prime} \mathrm{E}$ & -8 & $1 \cdot 21$ & 1982 \\
\hline 14142 & $41^{\prime \prime} 10^{\prime} \mathrm{N} 34^{\circ} 64^{\prime} \mathrm{E}$ & 5 & $2-25$ & 1983 \\
\hline 14143 & $41^{\circ} 85^{\prime} \mathrm{N}^{\prime} 32^{\circ} 22^{\prime} \mathrm{E}$ & -1 & 1.- 75 & 1983 \\
\hline 14145 & $39^{\circ} 38^{\prime} \mathrm{N} 35^{\circ} 02^{\prime} \mathrm{E}$ & 12 & $1-65$ & 1983 \\
\hline 14146 & $41^{\circ} 71^{\prime} \mathrm{N} 32^{\circ} 26^{\prime} \mathrm{E}$ & 20 & $1-33$ & 1983 \\
\hline 14183 & $41^{\circ} 91^{\prime} \mathrm{N} 32^{\circ} 17^{\prime} \mathrm{E}$ & -12 & 121 & 1983 \\
\hline 14428 & $41^{\circ} 68^{\prime} \mathrm{N} 32^{\circ} 41^{\prime} \mathrm{E}$ & 25 & $1-14$ & 1983 \\
\hline 14429 & $40^{\circ} 55^{\prime} \mathrm{N} 33^{\circ} 43^{\prime} \mathrm{E}$ & 5 & $1 \cdots 15$ & 1983 \\
\hline
\end{tabular}

often impure lignitic seam in this open cast mine. The samples were collected at one locality, with a vertical distance of $30 \mathrm{~cm}$, no.7808 being the lowermost and 14402 the uppermost sample. All the floras extracted from these samples are considered local autochthonous floras in contrast to those from the following samples which are considered as allochthonous extralocal floras: Samples 8297, 8300, 8334, 8335, 8336, 13285, 13286, 14401.

In Upper Miocene times a marine transgression eroded the lignite of the upper lignite seam along the Weisweiler fault. The top layer of the lignitic seam is pitted by teredines and at one place, at a distance of about $50 \mathrm{~m}$ from the
Weisweiler fault, a cliff-like palaeosurface, also perforated with teredines, could be observed. In places the lignite surface was not pitted and here a pattern of narrow channels was developed on the surface. At these places the lignite was covered by a thin layer of fine grained sand, white in colour and containing many coniferous cones and other organic material. Sample 14401 was collected from this material at about $50 \mathrm{~m}$ from the cliff face of the lignite. Overlying the marine-eroded lignite, a coarser sand, creamy in colour was present. Locally, clays with leaf impressions and accumulations of organic matter occur in which the larger parts were perforated by teredines. 
Sample 8336 was collected from such a clay, sample 13286 from an accumulation of organic matter.

These sands were incised by a $50-100 \mathrm{~m}$ wide river channel, containing alternate layers of coarse and fine white sand. Some of these layers contained organic material. Samples 8300,8335 and 13285 were collected from these sands, sample 8297 from a sandy clay at the border of the channel and sample 8334 was collected from a clay in a floodplain depression.

Several other samples have been collected, but they contained a fair amount of reworked material and could therefore not be used in this study.

From the lignite of the upper seam one sample was collected that yielded sufficient material for constructing an ecological comparison table: no. 14403. The flora of this sample is considered as autochthonous.

\section{Fortuna}

In the open cast mine "Fortuna" near Bedburg, three samples, nos. 8295, 8699 and 8700 , have been collected from a river channel in sandy deposits over the "Garzweiler" seam. These sands have been considered of Pliocene age, but the very typical mastixioidean flora found in it is an argument to place them in the Upper Miocene "Indener Schichten". One sample originates from the middle of the channel (no.8295), the other two from a facies near the border of it; no.8699 is from a sand, no. 8700 from a silt on top of the sand from which no.8699 was collected. These floras are considered as allochthonous.

\section{Hambach}

In the open cast mine "Hambach" near Düren several samples were collected in the uppermost part of the "Indener Schichten", a clay with some intercalated thin lignite seams. Sample 13349 originates from a slight depression in a locally lignitic developed clay layer, forming the top of the main clay. Sample 14429 is from a clay in a river channel just below the main clay. The material showed many monocotyledonous leaf impressions. The floras of these samples are considered as autochthonous local floras in contrast with the floras of the following samples.

Sample 14141 was collected in a sand from a river channel, also below the top clay of the "Indener Schichten". This is stratigraphically the oldest sample of the series of Hambach. Within the top clay there were shallow sandfilled channels, mainly in the upper part of the clay. From these channels samples 14139, $14140,14142,14143,14145,14146$ and 14428 were collected, the latter from a silt at the border of a channel from which sample 14140 was collected. Normally the coarse sands and gravels of the "Hauptkiesserie" overlie the uppermost clay. At one place a rhythmic succession of fine sands and silts was present between the top clay and the sands of the Hauptkiesserie. Sample 14183 was collected from this deposit.

\section{Methods}

All material was dried and sieved with sieves of $5 \mathrm{~mm}, 2 \mathrm{~mm}, 1 \mathrm{~mm}$ and $0.5 \mathrm{~mm}$ mesh apertures. Clays were boiled with sodium carbonate, lignite with sodium lye. After sieving, the residue was dried and floated over $\mathrm{CCl}_{4}$ and the fruits and seeds handpicked under a preparation microscope. The material was identified and stored in glass tubes and boxes in the collection of the Laboratory of Palaeobotany and Palynology under the above-mentioned sample numbers.

All material has been entered in the annotated taxa list from which a standard list of taxa has been prepared including indications of the floral elements (Arctotertiary and Palaeotropic), see Mai (1967, 1970a,b).

\section{Ecology}

In a previous paper (Van der Burgh, 1983), the vegetation of the low-lying plain was divided into nine compound vegetation units, 
TABLE II

Standardlist of taxa

\begin{tabular}{|c|c|c|c|c|c|}
\hline Acanthopanax solutus & $6^{\star}$ & $\mathrm{P}$ & Eurya stigmosa & $3^{\star}$ & $\mathrm{P}$ \\
\hline Acer campestre & 4,5 & A & Fagus decurrens & $6^{\star}$ & A \\
\hline Acer sp. cf. rufinerve & $6^{*}$ & A & Gaylussacia rhenana & 7,9 & A \\
\hline Acer sp. & $4,5,6$ & A & Glyptostrobus europaeus & $3^{\star}$ & A \\
\hline Actinidia faveolata & $4^{*}$ & $\mathrm{~A}$ & Halesia crassa & $6^{\star}$ & $\mathrm{A}$ \\
\hline Aluga antiqua & $5^{\star}$ & A & Homalanthus costatus & $3^{\star}$ & $\mathrm{P}$ \\
\hline Alisma plantago-aquatica & $2^{\star}$ & A & Hypericum holyi & 2,3 & A \\
\hline Alnus sp. & $3^{\star}$ & A & Hypericum sp. & & $\mathrm{P}$ \\
\hline Ampelopsis malvaeformis & $5^{*}$ & $\mathrm{P}$ & Ilex aquifolium & $6^{\star}$ & A \\
\hline Aracispermum canaliculatum & $2^{\star}$ & $\mathrm{P}$ & Ilex fortunense & $3,6,7$. & $\mathrm{P}$ \\
\hline Arctostaphyloides menzelii & $3,9^{\star}$. & $\mathrm{P}$ & Ilex jonkeri & $3,6,7$. & $P$ \\
\hline Asimina brownii & $5^{\star}$ & A & Ilex protogaea & $3^{\star}$ & A \\
\hline Betula sp. & $3,4,5,6,7$. & A & Ilex saxonica & $3,6,7$. & $\mathrm{P}$ \\
\hline Brasenia victoriae & $1^{*}$ & A & Ilex thuringiaca & $3^{*}$ & A \\
\hline Caldesia cylindrica & $2^{\star}$ & $\mathrm{P}$ & Juniperus oxycedrus & $3^{*}$ & A \\
\hline Carex acuta & $2^{*}$ & A & Laurocarpum sp. & & $\mathrm{P}$ \\
\hline Carex acutiformis & $2^{\star}$ & A & Leucothoe narbonnensis & $3,5,9$ & A \\
\hline Carex flagellata & $2^{*}$ & A & Liquidambar magniloculata & 5,6 & $\mathrm{~A}$ \\
\hline Carex hostiana & $2^{\star}$ & A & Liriodendron geminatum & $3,5^{\star}$. & $\mathrm{A}$ \\
\hline Carex sp. & & A & Lycopus europaeus & $2^{\star}$ & $\mathrm{A}$ \\
\hline Caricoidea jugata & $2^{*}$ & $\mathrm{P}$ & Magnolia burseracea & $3^{*}$ & $\mathrm{P}$ \\
\hline Carpinus betulus & $5^{\star}$ & A & Magnolia lignita & $3^{*}$ & $\mathrm{P}$ \\
\hline Carya ventricosa & $3^{*}$ & A & Magnolia lusatica & $3^{\star}$ & $\mathrm{P}$ \\
\hline Carya sp. vel Juglans sp. & & $\mathrm{A}$ & Magnolia sp. & $3^{*}$ & $\mathrm{P}$ \\
\hline Ceratophyllum demersus & $1^{*}$ & $\mathrm{~A}$ & Mastixia thomsonii & $3,5^{\star}$ & $\mathrm{P}$ \\
\hline Ceratophyllum submersum & $1^{\star}$ & A & Meliosma wetteraviensis & $3^{\star}$ & $\mathrm{P}$ \\
\hline Chionanthus ruehlii & $3^{*}$ & $\mathrm{P}$ & Menyanthes carpathica & $2^{\star}$ & A \\
\hline Chenopodium album & $2^{\star}$ & A & Mneme menzelii & $2^{\star}$ & $\mathrm{A}$ \\
\hline Cladiocarya europaea & $2^{*}$ & $\mathrm{P}$ & Myrica boveyana & $3,9^{*}$ & $\mathrm{P}$ \\
\hline Cladiocarya trebovensis & $2^{\star}$ & $\mathrm{P}$ & Myrica ceriferiformis & $3^{\star}$ & $\mathrm{A}$ \\
\hline Cladium reidiorum & $2^{*}$ & $\mathrm{P}$ & Myrica minima & $3^{\star}$ & A \\
\hline Comptonia costata & $8^{*}$ & A & Myrica sp. & 3,9 & \\
\hline Corema intermedia & $8^{*}$ & A & Myrica suppanii & $3,9^{\star}$. & $\mathrm{P}$ \\
\hline Cornus bugloviana & $3^{*}$ & $\mathrm{~A}$ & Nymphaea alba & $1^{\star}$ & $\mathrm{A}$ \\
\hline Cornus sp. & 4,6 & $\mathrm{~A}$ & Nymphaea sp. & $1^{*}$ & $\mathrm{~A}$ \\
\hline Corylopsis urselensis & $3,9^{\star}$. & A & Nyssa disseminata & $3^{*}$ & A \\
\hline Corylus avellana & $4^{*}$ & A & Nyssa ornithobroma & $3^{\star}$ & A \\
\hline Crataegus angusticarpa & $4,5,6$ & $\mathrm{~A}$ & Ostrya carpinifolia & $6^{\star}$ & A \\
\hline Crataegus jonkeri & $4,5,6$ & A & Ostrya scholzii & $5^{*}$ & $\mathrm{~A}$ \\
\hline Crataegus nodulosa & $4,5,6$ & A & Oxydendrum europaeum & 6.7 & $\mathrm{P}$ \\
\hline Crataegus sp. & $4,5,6$ & A & Paliurus sibiricus & $6^{\star}$. & A \\
\hline Cupressoconus rhenanus & $7^{*}$ & A & Palliopora symplocoides & $4,5,6$ & $\mathrm{P}$ \\
\hline Cyclocarya nucifera & $6^{*}$ & $\mathrm{~A}$ & Phellodendron lusaticum & $6^{\star}$ & A \\
\hline Decodon globosus & $2^{*}$ & A & Picea omorikoides & $7^{\star}$ & $\mathrm{A}$ \\
\hline Distylium uralense & $3^{*}$ & $\mathrm{~A}$ & Picea sp. & $7^{\star}$ & A \\
\hline Dulichium spathaceum & $2^{*}$ & $\mathrm{~A}$ & Pinaceae & $3,7,9$. & A \\
\hline Dulichium vespiforme & $2^{*}$ & A & Pinus leitzii & $3,7,9$ & A \\
\hline Empetrum nigrum & $3,9^{\star}$ & A & Pinus sp. & $3,7,9$ & A \\
\hline Eomastixia persicoides & $3^{*}$ & $\mathrm{P}$ & Pinus spinosa & $3,7,9$ & A \\
\hline Epacridicarpum mudense & $3,9^{*}$ & $\mathrm{P}$ & Pinus thomasiana & $3,7,9$ & A \\
\hline Epipremnites ornatus & $3^{*}$ & $\mathrm{P}$ & Pinus uranii & $3,7,9$. & A \\
\hline Erica palaeoarborea & $9^{\star}$ & A & Polyspora lignitica & $5^{\star}$ & $\mathrm{P}$ \\
\hline Ericaceae gen. et sp. indet. & $9^{\star}$ & & Potamogeton extremitatus & $1^{*}$ & A \\
\hline Eriophorum sp. & $9^{*}$ & $\mathrm{~A}$ & Potamogeton sp. & $1^{*}$ & A \\
\hline Eucommia europaea & $6^{*}$ & A & Proserpinaca reticulata & $3^{*}$ & A \\
\hline Eurya lusatica & $3^{*}$ & $\mathrm{P}$ & Pseudoeuryale europaea & $1^{*}$ & $\mathrm{~A}$ \\
\hline
\end{tabular}


TABLE II (continued)

\begin{tabular}{|c|c|c|c|c|c|}
\hline Pterocarya limburgensis & $3^{\star}$ & A & Symplocos germanica & $3^{\star}$. & $\mathbf{P}$ \\
\hline Punica natans & $6^{\star}$ & $\mathrm{P}$ & Symplocos gothanii & $3^{\star}$ & $\mathbf{P}$ \\
\hline Quercus robur & $5,6,7$. & A & Symplocos lignitarum & 3,5 . & $\mathbf{P}$ \\
\hline Rehderodendron ehernbergii & $4,5,6$ & $\mathrm{P}$ & Symplocos minutula & $3^{\star}$. & $\mathbf{P}$ \\
\hline Rubus laticostatus & $3,4,5,6,7,8$. & A & Symplocos pseudogregaria & $3,5^{*}$. & $\mathbf{P}$ \\
\hline Ruppia palaeomaritima & $1^{*}$ & A & Symplocos salzhausenensis & $3^{*}$ & $\mathbf{P}$ \\
\hline Sambucus pulchella & $3,4,5$. & A & Symplocos scherero & $5,6$. & $\mathbf{P}$ \\
\hline Sapium germanicum & $3^{*}$ & $\mathrm{P}$ & Taxodium dubium & $3^{*}$ & A \\
\hline Scindapsites crassus & $2^{*}$ & $P$ & Tectocarya rhenana & 3,5 . & $\mathbf{P}$ \\
\hline Scirpus lacustris & $2^{\star}$. & A & Tetrastigma lobata & $3,5^{*}$. & $\mathbf{P}$ \\
\hline Scirpus melanospermus & $2^{*}$ & A & Teucrium sp. & - & A \\
\hline Scirpus tabernaemontani & $2^{\star}$ & A & Toddalia naviculaeformis & $3^{*}$ & $\mathbf{P}$ \\
\hline Sequoia langsdorfi & $3^{\star}$. & A & Toddalia rhenana & $3^{*}$ & $\mathbf{P}$ \\
\hline Sinomenium militzeri & 4,5 . & A & Trapa heerii & $1^{*}$ & A \\
\hline Sium latifolium & $2^{\star}$ & A & Trigonobalanus exacantha & $6^{\star}$ & $\mathbf{P}$ \\
\hline Solanum nigrum & $2^{\star}$. & A & Typha sp. & $1^{\star}$. & A \\
\hline Sorbus aria & $6^{*}$. & A & Umbelliferopsis molassicus & $2^{\star}$ & A \\
\hline Sorbus herzogenrathensis & $3^{\star}$ & A & Urospathites cristatus & $2^{\star}$ & $\mathbf{P}$ \\
\hline Sparganium haentzschelii & $2^{\star}$. & A & Vaccinium miocenicum & 7,9 & A \\
\hline Sparganium minimum & $2^{\star}$ & A & Viola canina & $4^{*}$ & A \\
\hline Sparganium sp. & $2^{\star}$. & A & Viola rupestris & $7^{\star}$ & A \\
\hline Sphenotheca incurva & $4,5,6$ & $\mathbf{P}$ & Viscum sp. & $3^{*}$ & A \\
\hline Spirematospermum wetzleri & $2^{\star}$ & $\mathbf{P}$ & Vitis lusatica & $3^{\star}$ & A \\
\hline Staphylea bessarabica & $4,5,6$ & A & Vitis parasylvestris & 3,5 & A \\
\hline Staphylea sp. & $4,5,6$ & A & Vitis sp. & $3,5$. & A \\
\hline Stewartia beckeriana & $6^{*}$ & A & Vitis teutonica & $3,5^{\star}$. & $\mathbf{A}$ \\
\hline Stratiotes tuberculatus & $1^{\star}$ & A & Zanthoxylum ailanthiforme & $5^{*}$ & $\mathbf{P}$ \\
\hline Styrax maximus & $6^{\star}$. & $\mathbf{P}$ & Ziziphus striata & $3^{*}$ & - \\
\hline
\end{tabular}

roughly corresponding to physiognomical entities. These include:

(1) Open water vegetation; (2) Streamside vegetation; (3) Wetland forest (Carr and marsh forest, in Van der Burgh, 1983); (4) Forest border-scrub vegetation; (5) Floodplain forest; (6) Upland forest; (7) Coniferous forest; (8) Heath; (9) Peat bog.

These vegetation units make a rough subdivision of a vegetation which in reality was very complex, as it was influenced by a number of variable edaphic factors. The swamp, dominated by ferns and monocotyledonous plants as described by Mai and Walther (1978) is considered part of the streamside vegetation (Van der Burgh, in press). For definitions see Van der Burgh (1983).

The ecology of the flora is reconstructed using ecological composition tables (see Ap- pendix). Every taxon together with its number of remains has been entered in the column of the unit(s) in which it occurs. A taxon restricted to one unit or occurring predominantly in such a unit is considered characteristic and thus marked with an asterisk. The total of the taxa in a unit has been added and a percentage has been calculated with the total of taxa as $100 \%$. The same has been done with the characteristic taxa and with the remains of the characteristic taxa. These percentages have been added and the figures thus can be used as an expression of the ecological composition of the flora, and to compare the floras with each other.

In an attempt to trace the influence of the Palaeotropic floral elements in these floras all palaeotropical taxa have been underlined in the tables and, besides the general counts, 
added up separately and their percentages calculated against the totals of the general counts. By subtracting the figures thus obtained from the figures obtained from the general counts, the relationship palaeotropic arctotertiary plants can be determined (some plants are indifferent, but their number is very small and they have not been taken into account). The figures are shown in block diagrams to enable easy comparison of the floras.

The samples were poorly sorted with regard to the diameter of the seeds and fruits which ranges from 0.8 to $10(80) \mathrm{mm}$ (see also Table I). The only sample with relatively well-sorted material, ranging from $1.5-5.0 \mathrm{~mm}$ with a maximum of about $3 \mathrm{~mm}$, was no.14403, originating from the upper lignitic seam in " $\mathrm{Zu}$ kunft West". Although the lignite is considered an autochthonous sediment it is nevertheless possible that parts of it were inundated temporarily or more or less continuously, resulting in some sorting of the fruits and seeds. An argument for this supposition is the observation that the seeds occur in thin layers throughout the locally not very homogeneous lignite, separated by thicker barren layers. Normally the lignite is very amorphous and does not yield recognisable fruits and seeds.

As emphasized by their poor sorting, all other samples reveal a representative reflection of the total of seeds available and can therefore be compared with one another, because sedimentation evidently influenced the seed and fruit content only to a limited extent. Differences in the sedimentological regime have been accounted for in the discussion resulting in slight corrections in the reconstruction of the vegetation.

\section{Annotated list of taxa}

In the following section only those taxa are described and illustrated which do not occur in previous papers of the author (Van der Burgh, 1978,1983 , in press). An exception is made for taxa for which additional information was available. The ecology is briefly described and a subsequent grouping within one or more of the nine vegetational units is suggested.

\section{CUPRESSACEAE}

Cupressoconus rhenanus Kilpper (Plate I, 1, 5, 6, 8, 9)

Material studied: Cones; coll. no.14401-20: 11; seeds; coll. no.14401-21: 94.

Remarks: The cones are similar to C. rhenanus described by Kilpper (1968b). They measure $11 \cdots 22 \mathrm{~mm}$, are globose and bear more than two seeds per scale. The scales are opposite and there are 46 pairs of them. Ridges radiate from a central protuberance on the outer surface of the scale. From one of these cones seeds were extracted which are similar to those found dispersed in the sample.

The seeds are $1.5 \quad 3.5 \times 12 \mathrm{~mm}$ and irregular. The surface is black and glossy. Two or three ridges are present and sometimes the surface bears numerous warts. The hilum is irregular, the apex apiculate. The ventral ridge is blunt, the other two ridges wing-like. These seeds are similar to those of Cupressus benthamii Endlicher and C. pygmaea Sargent from the American continent and to those of C. duclouxiana Hickel from the Asiatic continent. They are similar to the seeds extracted from Cupressoconus rhenanus.

Ecology: The only occurrence is in an allochthonous flora which had been deposited in proximity of the coast (50-100 $\mathrm{m}$ distance). This suggests a dry, well-drained habitat. At the present day Cupressus forms woody vegetations under rather dry circumstances, alone or in combination with other conifers. It is therefore assigned to the coniferous forest, unit 7.

Juniperus oxycedrus $\mathbf{L}$.

Material studied: Seeds; coll. no.7808-22: 2.

Ecology: See Van der Burgh (in press).

PLATE I

1,5,6. Cupressoconus rhenanus; seed; no.14401-21; 1 : $25 \times ; 5,6: 12.5 \times$.

2. Pinus thomasiana; no.14143-1; $1 \times$.

3. Pinus leitzii; cone axis; no.14139-30; $1 \times$.

4. Pinus uranii; no.14401-13; $1 \times$

7,10. Picea omorikoides; no.8295-66; $1 \times$.

8.9. Cupressoconus rhenanus; cone; no.14401-20; $1 \times$.

11. Pinus spinosa; no.14401-47; $1 \times$.

12. Pinus leitzii; no. 14145-1; $1 \times$. 


\section{PLATE I}
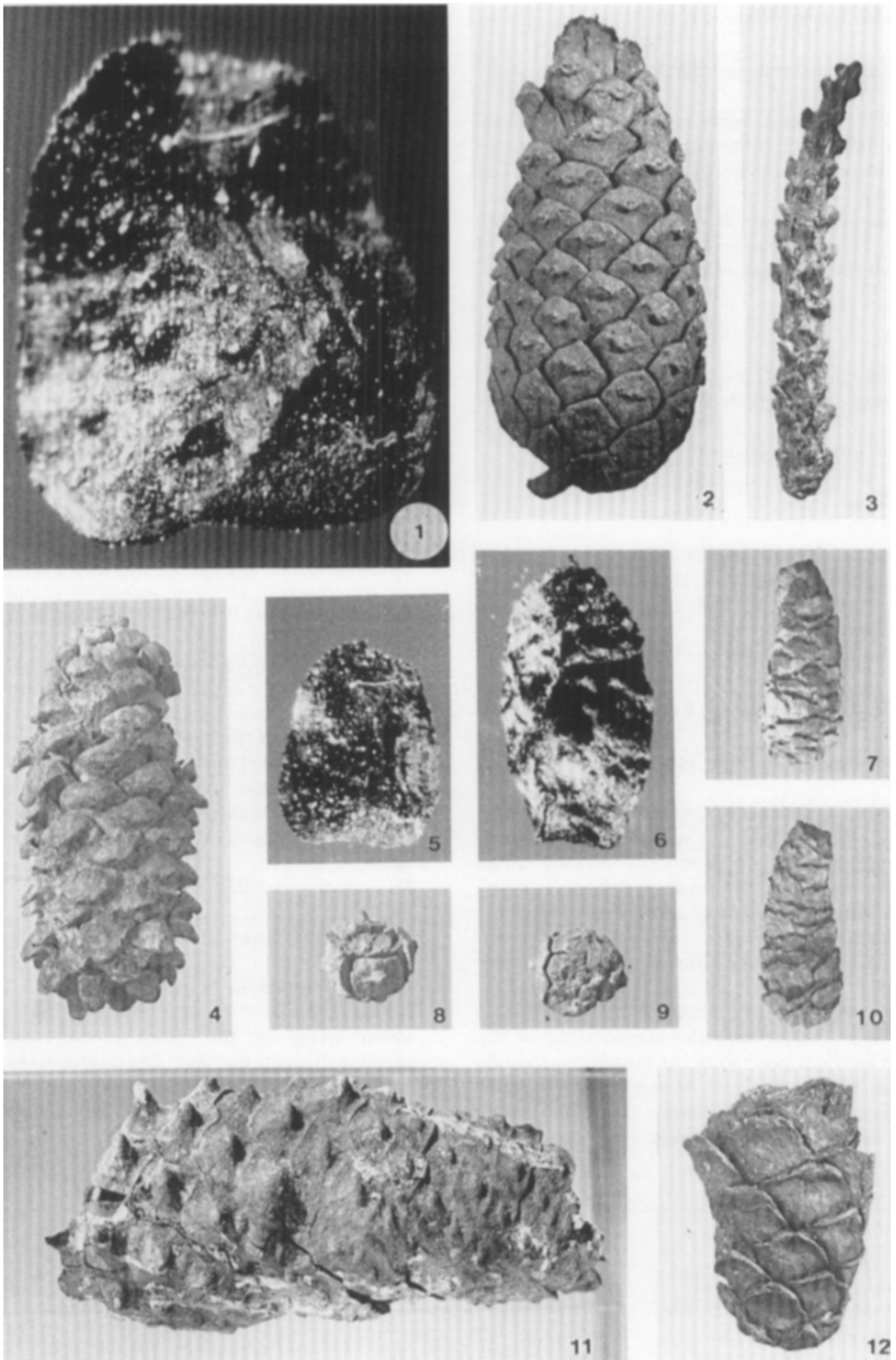


\section{PINACEAE}

Picea omorikoides Weber (Plate I, 7, 10)

Material studied: Cones; coll. no.8295-66: 1; 8699-2: 1; 14139 . 31: 1 .

Remarks: $36-38 \times 15-19 \mathrm{~mm}$ cones with thin wide scales. They are badly damaged but their similarity to $P$. omorika (Pancic) Purkyne is still evident. They have been identified as $P$. omorikoides.

Ecology: This species is known from Miocene and Pliocene sandy deposits. This is in accordance with the ecology of the recent $P$. omorika, a plant of coniferous forest, unit 7 .

\section{Picea sp.}

Material studied: cones; coll. no.14140-9: 1.

Remarks: A juvenile cone which cannot be assigned to any one species.

Ecology: See the preceding species.

Pinaceae gen. et sp. indet.

Material studied: Seeds; coll. no.7808-24: 1; 8295-40: 9; 83004: 2 ; 8699-17: 2 ; 13285-27: 1 ; 14139-6: 17; 14140-18: 2; 14143-7: 4 ; 14145-13: 12 ; 14146-21: 1 ; 14183-4: 13 ; 14401-6: 16; cones: 14401-6: one immature cone.

Ecology: See Van der Burgh (in press).

Pinus leitzii Kirchheimer (Plate I, 3, 12)

Material studied: Cones: coll. no. 14139-29: 12; 14143-2: 6; 14145-1: 18

Remarks: Cones up to $100 \mathrm{~mm}$ long and $35 \mathrm{~mm}$ broad. The axis is narrow (5-8 mm diameter) with slender adhering scale bases. Scales thin and longitudinally striated. Umbo at the apex of the scale. These cones are similar to $P$. leitzii as described by Kirchheimer (1936) and Kilpper (1968a).

Ecology: Pines of several sections of the genus are known from the lignite of the lower Rhenish basin (Van der Burgh, 1964, 1973).

Although it is not possible to identify cones with xylotomous taxa, it is still clear that the environment of the genus included nutrient poor soils. At present, such soils not only consist of peat but also of sand, and pines are known from vegetations which include units 3,7 and 9 . Samples from lignite and sand deposits (Van der Burgh,
1983) suggest that in Neogene times the pines occupied comparable ecological niches.

Pinus sp. (diploxytic sections)

Material studied: Scales; coll. no.13286-14: 2; 14183-4: 4; cones; 14145-2: 7 .

Remarks: Very strongly abraded or deformed thick cones or isolated scales, which cannot be identified to the species level. They clearly belong to one or several species of the diploxytic sections with massive lignified cones consisting of thick lignified axes and ditto scales.

Ecology: See P. leitzii.

Pinus spinosa Herbst (Plate I, 11)

Material studied: Cones; coll. no.14140-8: 1; 14401-47: 1.

Remarks: Both cones are incomplete: one (14140-8) represents only part of the base of a cone, the other (14401-47) lacks the apex and part of the base. Nevertheless, this elongate cone with its characteristic short spines on the scales on one side of the cone can be compared with $P$. spinosa as redescribed by Mai (1965) and also with the description of Kilpper (1968a) and Schloemer-Jäger (1960). Ecology: See P. leitzii.

Pinus thomasiana (Goeppert) Reichenbach (Plate I, 2)

Material studied: Cones; coll. no.14143-1: 3; 14401-48: 3 . Remarks: $65-85 \times 38-40 \mathrm{~mm}$ slightly oblique cones with rhombic to pentamerous apophyses. The umbo, which is in the upper part of the apophyse, is very short, knoblike and equally developed on all sides of the cone. The cones possess a $7-10 \mathrm{~mm}$ long stout stalk. This material can be compared with $P$. thomasiana as described by Kirchheimer (1936) and Schloemer-Jäger (1960) from the lower Rhenish basin.

Ecology: See P. leitzii.

Pinus uranii (Unger) Schimper (Plate I, 4; Plate Il, 1)

Material studied: Cones; coll. no.14401-13: 14.

Remarks: These $40-85 \times 27-50 \mathrm{~mm}$ oblique cones with very strong spines on the scales at the long side are very variable in shape and size. The only species which matches our material is P. uranii as described by Kilpper (1968a) from the Indener Series in the same quarry. Ecology: See P. leitzii.

\section{PLATE II}

1. Pinus uranii; no.14401-13; $1 \times$.

2. Asimina brownii; no.14145-22; $6 \times$.

3. Acer rufinerve; Recent; $12.5 \times$

4. Ilex protogaea; no.8335-26; $12.5 \times$

5. Acer sp. cf. rufinerve; no.14141-13; $12.5 \times$.

6,7. Acanthopanax solutus; no.14146-7; $12.5 \times$.

8. Chenopodium album; no.8295-76; $25 \times$. 
PLATE II
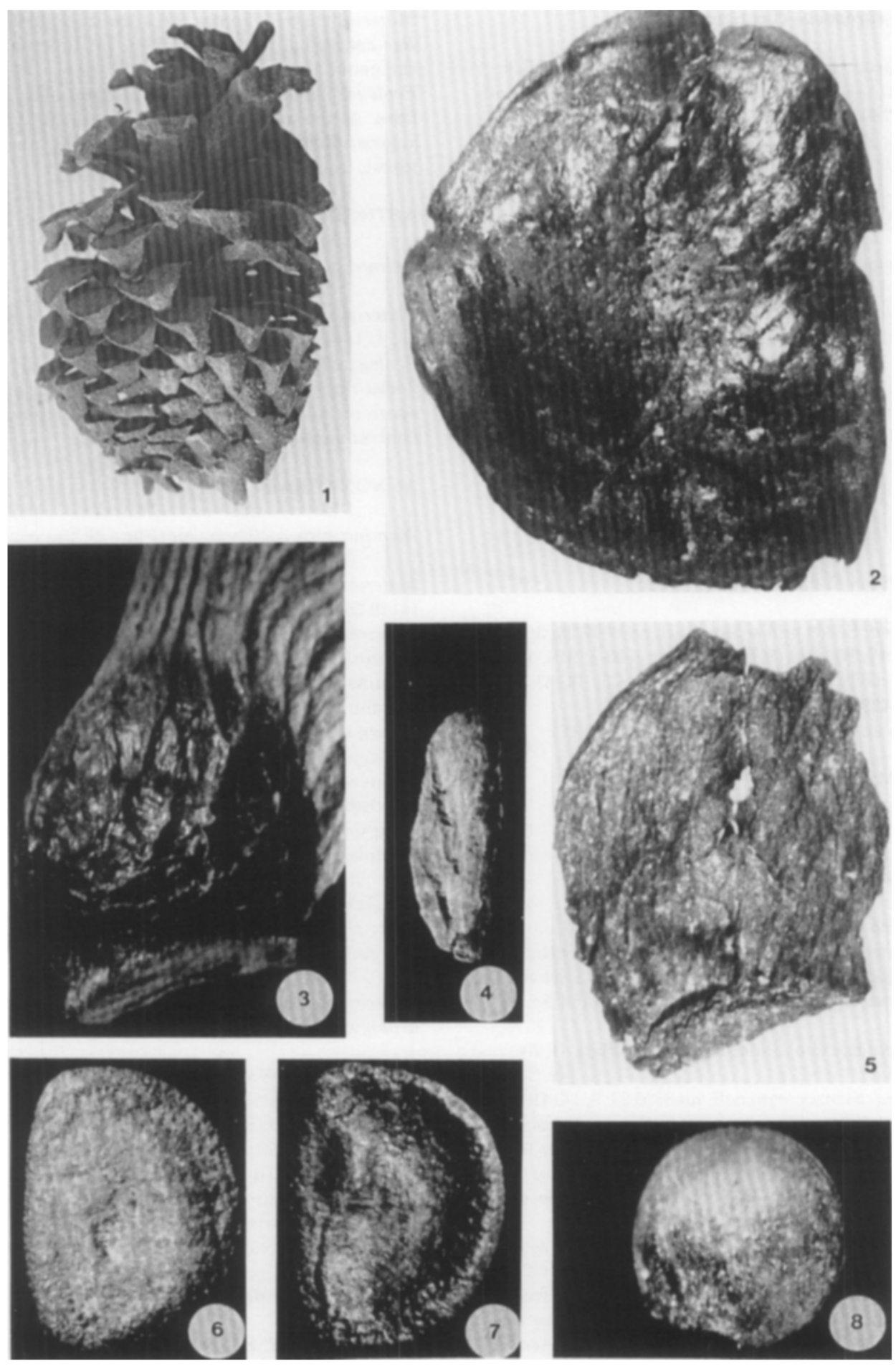


\section{TAXODIACEAE}

Glyptostrobus europaeus (Brongniart) Unger

Material studied: Cones; coll. no.13286-11: 11; 13349-3: 1; 14140-7: 65; 14143-5: 26; 14146-22: 10; 14429-2: 6; seeds; coll. no.7807-6: 18; 7808-2: 5 ; 7809-7: 1 ; 8295-42: $11 ; 8297-2$ : 8; 8336 17: $1 ; 8700-3: 3$; 13349-3: 16 ; 14139-12: 6; 14140-17: 120; 14141 . 4: 11; 14143-6: 5; 14145-9: 1 ; 14146-23: 72; 14399-3: 47; 14400-3: 11; 14401-7: 1; 14402-12: 10; 14429-3: 209.

Ecology: See Van der Burgh (in press) (unit 3).

\section{Sequoia langsdorfii (Brongniart) Heer}

Material studied: Cones: coll. no.8295-23: 554; 8699-1: 121; 13285-2: 63; 14139-13: 40; 14140-6: 127; 14141-12: 1; 14142-10: 2; 14143-3: 52; 14145-3: 26; 14146-24: 20; 14183-25: 2; 14399-4: 9; 14400-4: 6 ; 14401-18; 4; 14402-4; 3; seeds: coll. no.7808-13: 17; 8295-23: 3025; 8297-3: 44; 8300-6: 38; 8335-7: 209; 8336-9: 23 ; 8699-1: 140; 8700-1: 13; 13285-2: 155; 13286-16: 32; 1413914: 129 ; $14140-16$ : 156 ; 14143-4: 52 ; 14145-19; 48; 14146-25: 161 ; 14183-25: 4; 14399-5: 139; 14400-5: 291; 14401-19: 40; 14402-5: 23; 14403-9: 1 .

Ecology: See Van der Burgh (in press) (unit 3).

Taxodium dubium (Von Sternberg) Heer

Material studied: Seeds and scales; coll. no.7807-25: 3; 829525: 97; 8297-1: 17; 8336-23: 2; 8699-3: 223; 8700-2: 918; 13286 . 13: 3 ; 13349-4: 688 ; 14141-46: 1407; 14142-4: 6 ; 14183-3: 42; 14428-4: 12; 14429-4: 176.

Ecology: See Van der Burgh (1983, in press) (unit ?).

\section{ANGIOSPERMAE}

\section{ACERACEAE}

Acer campestre L.

Material studied: Schizocarps; coll. no.14183-11: 1 . Ecology: The material has been found in an allochthonous flora. Nowadays, Acer campestre forms part of moist to dry forest and forest border communities, units 4 and 5 .

Acer sp. cf. rufinerve Siebold et Zuccarini (Plate II, 5)

Material studied: Schizocarps: coll. no.8336-24: 9; 14141-13: 9 . Remarks: These $5 \times 4 \mathrm{~mm}$ schizocarps without wing show a very distinct venation. The longest axis of the fruit forms an angle of about $90^{\circ}$ with the dehiscence plane, the wing is given off at an angle of $45^{\circ}$. These fruits show some similarity to $A$. rufinerve from Japan (Plate II, 3).

According to Mai $(1983,1984)$ the fruits of the section Platanoidea also show a distinct venation pattern. These are flattened in contrast with the almost globular fruit of A. rufinerve, and they are also larger than the material described here. Therefore this material belongs to Acer sp. cf. rufinerve.

Ecology: This species has been found in allochthonous floras only; recent $A$. rufinerve is a tree of upland forest, unit 6 .
Acer sp.

Material studied: Schizocarps: coll. no.8335-11: 1; 8700-7: 1 . Remarks: Small schizocarps as yet unidentifiable beyond the genus level.

Ecology: The material has been found in an allochthonous flora. At the present day Acer is a shrub or tree in various vegetations, ranging from floodplain forest to upland forest, unit 4,5 and 6 .

\section{ACTINIDIACEAE}

\section{Actinidia faveolata Reid et Reid}

Material studied: Seeds; coll. no.8295-41: 1; 8300-22: 1; 8699 35: 4; 14141-2: 15; 14183-30: 2.

Ecology: This species has been found in allochthonous floras only. Recent Actinidia is a plant of thickets and scrub on rather fertile soil, unit 4 ; our records are not in contradiction with these conditions.

\section{ANNONACEAE}

Asimina brownii Thomson (Plate II, 2)

Material studied: Seeds; coll. no.8699-31: 2; 13285-25: 1 ; 14139-28: 2; 14145-22: 4

Remarks: Large, 15-22 $\times 11-14 \mathrm{~mm}$ seeds with a long hilum on the narrow side. The surface is glossy with a fine cellular pattern. Most seeds are deformed or broken, due to the thin testa. They resemble A.triloba Dunal and are known in the literature under $A$. brownii (Thomson, 1954). Ecology: Recent A. triloba is a plant of floodplains and rich damp woods. The occurrence of seeds of $A$. brownii in allochthonous floras only would also suggest a habitat alongside rivers. It is therefore assumed to have grown in floodplain forest, unit 5 .

\section{AQUIFOLIACEAE}

Ilex aquifolium $\mathrm{L}$.

Material studied: Endocarps; coll. no.14145-28: 1.

Ecology: Dry upland forest in a moist climate, unit 6 .

Ilex fortunensis Van der Burgh

Material studied: Endocarps; coll. no.8300-20: 1.

Ecology: As I.fortunensis is not yet matched with any recent species, it is impossible to specify its ecology. According to Mai (1970c) Ilex is predominantly a genus of moist climate, with a preference for moist to wet, often peaty soils or forest with much raw humus, units 3,6 and 7 .

Ilex jonkeri Van der Burgh

Material studied: Endocarps; coll. no.7808-27: 1. Ecology: See Van der Burgh (in press) (units 3,6 and 7)

Ilex protogaea Mai (Plate II, 4) 
Material studied: Endocarps; coll. no.8335-26: 1; 14146-3: 1; 14401-10: 1 .

Remarks: These three endocarps, $3.0-3.5 \times 1.0-1.4 \mathrm{~mm}$, bear ridges on the outer side as well as on the lateral faces. These lateral faces form an acute angle with each other. The ridges on the outer side anastomose, forming a more or less reticulate pattern; the ridges on the lateral planes divide and become thinner towards the apex. This material clearly belongs to the genus Ilex and is similar to I. protogaea, described by Mai (1970a,b,c).

Ecology: This species shows similarities with $I$. cassine L. from swamps in Virginia and Florida in the USA. Our allochthonous finds are not in contradiction with these conditions, so it is considered a plant of wetland forest, unit 3 .

\section{Ilex saxonica Mai}

Material studied: Endocarps; coll. no.7808-14: 2; 8295-39: 1; 13286-27: 1; 14140-25: 3; 14399-6: 2; 14429-7: 13.

Ecology: See Van der Burgh (in press) (unit 3,6 and 7).

\section{Ilex thuringiaca Mai}

Material studied: Endocarps; coll. no.7807-21: 1.

Ecology: See Van der Burgh (in press) (unit 3).

\section{ARALIACEAE}

Acanthopanax solutus Gregor (Plate II, 6, 7)

Material studied: Endocarps; coll. no.8295-77: 1; 8300-15: 2; 8336-38: 2 ; 14139-10: 1; 14146-7: 1.

Remarks: Flattened endocarps with a straight and a semicircular outline. They measure $4.0-4.6 \times 2.4-3.2 \mathrm{~mm}$. The surface is smooth with a fine cellular pattern and sometimes a thin cross striation. These endocarps are similar to the material described by Gregor (1977).

Ecology: The material has been found in allochthonous floras only. Gregor (1978a, 1980) reported the species from allochthonous floras or from autochthonous floras with allochthonous influences. The present-day ecological conditions of the genus constitutes forests and thickets on rather fertile well-drained soil, unit 6 . The fossil finds are in accordance with this ecology.

\section{BETULACEAE}

\section{Alnus sp.}

Material described: Cones; coll. no.7807-26: 3; 8700-11: 4; 13349-2: 49; 14428-1: 5; 14429-8: 20; nuts; coll. no.8295-13: 6; 8297-6: 1 ; 8300-3: 1 ; 8335-6: $11 ; 8336-13: 7 ; 8699-37: 1 ; 8700-11: 4$; 13285-30: 1 ; 13286-21: 4 ; 14141-20: 48; 14183-26: 5; 14429-9: 76. Ecology: Alnus is generally a plant of wetland forest, unit 3 (Van der Burgh, 1983).

\section{Betula sp.}

Material studied: Nuts; coll. no.14183-21: 7.
Ecology: The present-day ecology of the genus comprises all types of forest, units $3,4,5,6$ and 7 .

Carpinus betulus $\mathrm{L}$.

Material studied: Nuts; coll. no.8295-12: 5; 14428-6: 1.

Ecology: This species has been found in allochthonous floras. Recent hornbeam forms part of moist forest vegetation, especially floodplain forest. The fossil finds are not in contradiction with this ecology, unit 5.

Corylus avellana $\mathrm{L}$.

Material studied: Nuts; coll. no.8295.21: 1. Ecology: See Van der Burgh (1983) (unit 4).

Ostrya carpinifolia Scopoli

Material studied: Nuts; coll. no.8297-29: 3; 8335-4: 2 .

Ecology: At the present day this species is a plant of dry upland forest. Our material has been found in allochthonous floras only, which agrees with these conditions, unit 6 .

\section{Ostrya scholzii Gregor}

Material studied: Nuts; coll. no.8295-64: 27; 8297-7: 32; 830019: 2 ; 8335-3: 34; 8336-27: 65; 8699-6: 418; 8700-6: 247 ; 13286 10: 27 ; 14141-15: 52; 14142-11: 1; 14183-10: 34; 14399-25: 1 . Ecology: The majority of our material has been found in allochthonous floras, especially in those of fine grained sand and clay deposits. Although Gregor (1982) reports the species from autochthonous floras in Bavaria our findings indicate a species of the floodplain forest, unit 5, (Van der Burgh, in press).

\section{CAPRIFOLIACEAE}

Sambucus pulchella Reid et Reid

Material studied: Endocarps; coll. no.7807-12: 1; 8336-4: 1; 14141-6: 1; 14183-31: 9; 14401-3: 1 .

Ecology: See Van der Burgh (in press) (units 3, 5 and 5).

\section{CARYOPHYLLACEAE}

Stellaria media (L.) Villars (Plate III, 4)

Material studied: Seeds; coll. no.8295-65: 1.

Remarks: a small circular campylotropous seed, diameter $1.1 \mathrm{~mm}$, damaged on the flat sides, but on the circular narrow side sufficiently complete to allow comparison with recent Stellaria media (Plate III, 7).

Ecology: Recent $S$. media is a pioneerplant, occurring in any open environment. It has been assigned to unit 2 .

\section{CERATOPHYLLACEAE}

Ceratophyllum demersum $\mathrm{L}$.

Material studied: Fruits; coll. no.8295-53: 3. 
Ecology: This plant, typical of open water, has been found once in a river deposit. Gregor (1982) reported it from lignitic clay and clay in $\mathrm{S}$. Germany. It is considered a plant of open water communities in rather quiet circumstances, unit 1.

\section{Ceratophyllum submersum L.}

Material studied: Fruits; coll. no.8300-24: 2; 13349-17: 70; 14141-40: 1; 14428-11: 2.

Ecology: See Van der Burgh (in press) (unit 1).

\section{CHENOPODIACEAE}

Chenopodium album L. (Plate II, 8)

Material studied: Seeds; coll. no.8295-76: 7 .

Remarks: These 1.0-1.2 mm diameter round shiny black campylotropous seeds have a width of about $0.8 \mathrm{~mm}$. They are identical to seeds of recent C. album, except for the lustre, which is not so pronounced in the fossil material. Ecology: Recent Chenopodium album is a plant of disrupted vegetation, especially when bare soil is exposed. The find in an allochthonous flora in a river channel is in accordance with this ecosystem, unit 2 .

\section{CORNACEAE}

Cornus bugloviana (Negru) Van der Burgh

Material studied: Endocarps; coll. no.7807-14: 3; 7808-23: 1; 14141-44: 3 .

Ecology: See Van der Burgh (in press) (unit 3).

Cornus sp.

Material studied: Endocarps; coll. no.8700-43: 6 .

Remarks: These fragments of bilocular endocarps frequently bear ridges and grooves from veins on the outer side. The material bears some similarities with endocarps from $C$. controversa but it is too fragmentary for specific identification.

Ecology: As no comparable species have been determined and the material has been found only in an allochthonous flora, the ecology of the present-day representatives of the genus has to be considered. This is rather variable, ranging from forest to scrub and forest border (Van der Burgh, 1983), (unit 4 and 6).

\section{EMPETRACEAE}

Corema intermedia Reid et Reid (Plate III, 1, 2, 3)

Material studied: Fruits and endocarps; coll. no.14401-30: 25.

Remarks: The fruits contain two to three endocarps. The endocarps bear three to four ribs on the outer dorsal surface. The ventral side bears a median groove between two low rounded ridges. The endocarps measure 1.2 $2.1 \times 0.9-1.4 \mathrm{~mm}$. This material is similar to that described by Reid and Reid (1914) as C. intermedia from Britain and the Netherlands.

Ecology: Recent Corema is a plant of coastal heath formations in Western Spain and Portugal and in eastern North America. It is therefore considered a plant of heathland, unit 8 .

Empetrum nigrum L.

Material studied: Seeds; coll. no.8300-17: 1; 8335-27: 1; 8700-9: 7 ; 14146-4: 1 ; 14399-34: 1 ; 14400-14: 2 ; 14401-27: 2; 14402-24; 3.

\section{ERICACEAE}

Arctostaphyloides menzelii Kirchheimer

Material studied: Fruits; coll. no.8295-20: 4; 13285-12: 5 ; 14401-12: 30.

Ecology: This plant has been collected mainly from "Zukunft West" at Eschweiler. The highest percentage was found in a deposit in which the influence of lignite moors could be expected. Therefore, it is considered a plant of wetlands and especially of peat bog, units 3 and 9 .

Epacridicarpum mudense Chandler (Plate III, 9; Plate V, 1,2)

Material studied: Capsules; coll. no.8295-51: 2; 8300-2: 340; 8335-10: 167; 8336-14: 75; 13285-11: 37; 13286-12: 8; 14401-39: 60; 14403-6: 20.

Remarks: This fruit, identified as Epacridicarpum mudense, described by Chandler (1960), can be compared with the capsule of Gaultheria (Plate V, 7). However, the capsule of this genus is leathery and not woody. Also in Gaultheria there is a woody stalk-like or gynophore-like structure between the base of the fruit and the capsule, caused by the development of the corolla after fertilisation. In addition

\section{PLATE III}

1,2,3. Corema intermedia; no.14401-30; $25 \times$.

4. Stellaria media; no.8295-65; $25 \times$.

5,6. Ericaceae, gen. et sp. indet. 1; no.14401-41; $25 \times$.

7. Stellaria media; Recent; $25 \times$.

8. Ericaceae, gen. et sp. indet. 2 ; no.14401-43; $12.5 \times$.

9. Epacridicarpum mudense; no.8335-10; $12.5 \times$. 
PLATE III
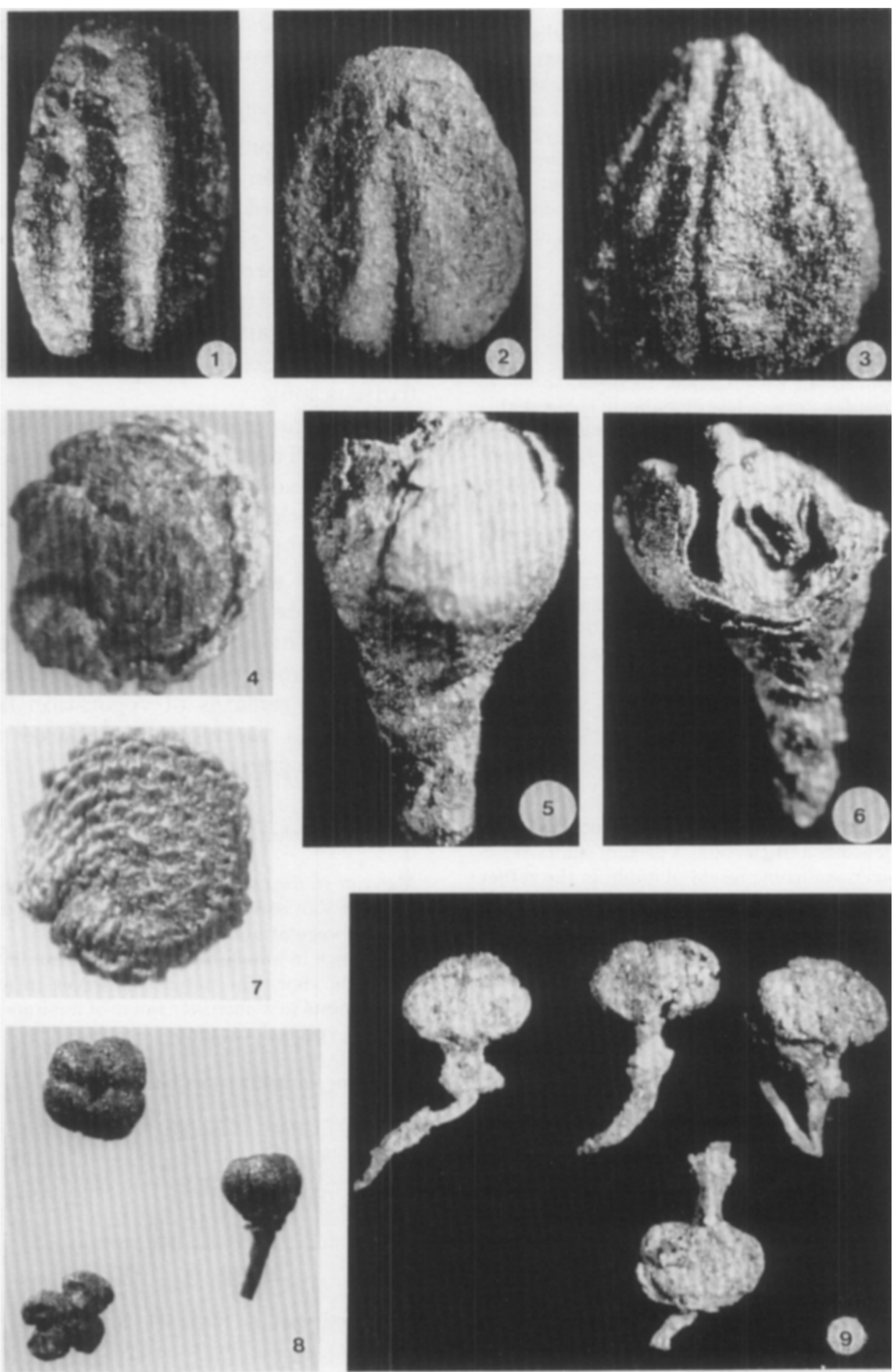
to these structures the material of sample 8335 contains fruit stalks of up to three mm length and a lobed apex of the style.

Ecology: This species has been found mainly in allochthonous floras. The material of sample nos. 8300, 8335, 8336, 13285,13286 and 14401 originates from river channels in a rather thin sandy deposit over the lignite and contains numerous remains derived from it. Sample 14403 originates from the lignite itself (the upper seam) which is very pure, reflecting an oligotrophic peatbog environment. This species is therefore considered to be a plant of peat-forming and more particularly oligotrophic vegetations, units 3 and especially 9.

ERICACEAE gen. et sp. indet. 1 (Plate III, 5, 6)

Material studied: Capsules; coll. no.14401-42: 309.

Remarks: Small, 1.1-1.9 $0.9-1.2 \mathrm{~mm}$, lignified, three- to four locular capsules more or less globular in shape with a rather coarse cellular pattern, mostly preserved together with remains of the perianth. Some of them bear a stout style, $0.3-0.5 \mathrm{~mm}$ long, with a circular stigma at the top. The massive stalks are covered by crowded opposite scales. These capsules have many characteristics in common with the Ericaceae, but cannot be ascribed to any genus.

Ecology: This material has only been found in an allochthonous flora, characterised by numerous traces of the vegetation from the underlying lignite seam. Therefore, it is considered to have originated from a peatbog vegetation, unit 9 .

ERICACEAE gen. et sp. indet. 2 (Plate III, 8; Plate IV, $9,10)$

\footnotetext{
Material studied: Capsules; coll. no.14401-43: 14.

Remarks: Small globular to four-lobed, four-locular fruits, sometimes attached to a thick stalk. A certain similarity to other ericaceous remains is present, notably in the rather coarse cellular structure. However, it is not possible to match the material with any recent genus.

Ecology: See the preceding species.

Erica palaeoarborea nov. spec. (Plate IV , 1, 2, 4, $5,6)$

Holotype: Coll. no.14401-40a (Plate IV, 1). Paratypes: Coll. no.14401-40b (Plate IV, 2, 4, $5,6)$.
}

Locus typicus: Quarry "Zukunft West" at Eschweiler.

Stratum typicum: Indener Schichten.

Derivatio nominis: From its similarity with E. arborea.

Description: Three to four locular capsules, $0.8-1.0 \mathrm{~mm}$ long and wide, slightly elongate to globular, open loculicide and often enclosed in the remains of the perianth. Perianth ca $1 \mathrm{~mm}$ in diameter, globular in outline, sympetalous with four more or less triangular petal apexes. Calyx consisting of four scale-like triangular sepals. The capsule bears a stout style, ca $1 \mathrm{~mm}$ long, with a circular stigma. The stalk of the fruits is long.

Material studied: Capsules; coll. no.14401-40: 99. Remarks: These capsules are comparable with those of some species of Erica, especially $E$. arborea and to a lesser degree E. scoparia, except that the fossil material is half the size of the recent species. Therefore it is considered here as a new species.

Ecology: This material has only been found in allochthonous floras, both of which contained numerous remains of vegetation from lignite bogs. It is therefore considered a plant of peatbog vegetation, unit 9 .

\section{Gaylussacia rhenana Van der Burgh}

Material studied: Seeds; coll. no.8300-16: 2; 8336-37: 1 . Ecology: Van der Burgh (1983) considered this a genus of upland vegetations and peat, units 3,7 and 9 . The occurrence in allochthonous floras is not in contradiction with this view. The absence however in autochthonous floras points to a narrower range of habitats excluding the wetland vegetations; units 7 and 9 .

Leucothoe narbonnensis (Saporta) Mai

Material studied: Capsules; coll. no.8297-30: 2; 8300-13: 1; 13285-10: 6 .

\section{PLATE IV}

1,2,4,5,6. Erica palaeoarborea; 1: Holotype, no.14401-40a; $25 \times .2,4,5,6$ : Paratypes, no.14401-40b; $25 \times$.

3. $\quad$ Erica arborea; Recent; $12.5 \times$.

7. Hypericum holyi; no.7809-4; $25 \times$.

8. Hypericum sp.; no.14401-49; $25 \times$

9,10. Ericaceae, gen et sp. indet. 2; no.14401-43; $25 \times$. 
PLATE IV
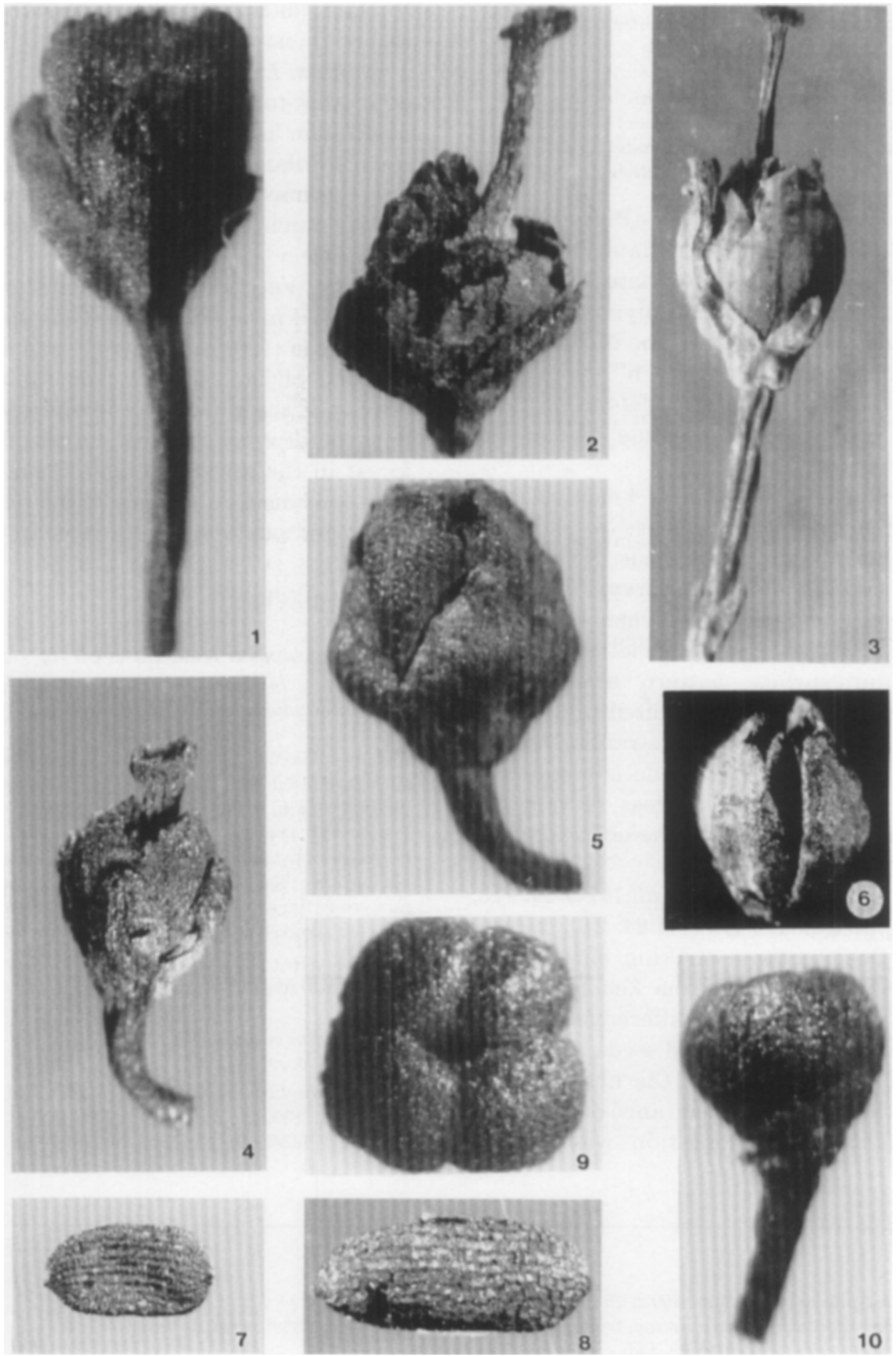
Ecology: Gregor (1980) and Mai (1964) reported the species from autochthonous floras. In the lower Rhenish basin it is known from allochthonous floras only. Thus the ecology of the species comprises different habitats, as pointed out by Van der Burgh (1983), units 3, 5 and 9.

Oxydendrum europaeum Van der Burgh

Material studied: Capsules; coll. no.8295-55: 1. Ecology: See Van der Burgh (1983) (units 6, 7).

Vaccinium miocenicum nov. sp. (Plate V, 3, 4) Holotype: Coll. no.14141-24a, (Plate V, 3) Paratype: Coll. no.14141-24b, (Plate V, 4), Laboratory of Palaeobotany and Palynology of the State University of Utrecht, The Netherlands. Locus typicus: Quarry "Hambach".

Stratum typicum: Indener Schichten.

Derivatio nominis: The Miocene age of the stratum typicum.

Description: The fruits are 3-4 mm circular flattened remains of subglobose to globular berries, containing up to six seeds. No remains of calyx or corolla could be observed. The seeds are 1-2 $\mathrm{mm}$ long and $1.0-1.5 \mathrm{~mm}$ wide, deformed, with a slightly isodiametric to elongate cellular surface pattern and a wall $0.10-0.15 \mathrm{~mm}$ thick. The elongated hilum is at the base of the more or less straight ventral side of the seed. The dorsal side is angular to curved or semiglobose. In cross section the seeds are triangular, due to the occurrence of 4-6, mostly 5 in a fruit.

Material studied: Fruits; coll. no.14141-24: 110; seeds; coll. no.8335-28: 1; 14141-24: 240.

Remarks: Despite some striking similarities, this material is different from Zenobia fasterholtensis (Friis, 1985). The differences are the greater size of both fruits and seeds, the lesser amount of seeds in a fruit, the absence of a caly $x$ and the flattened appearance of the fruits pointing to a fleshy condition when fresh.
Berries with rather few, 1-2 mm long seeds with a reticulate seedcoat are known from the Vaccinioideae. The seeds of Gaylussacia have a rather thick, stony appearance, while those of Vaccinium have a thin seedcoat. Our material is similar to that of $V$. ovatum Pursh. Fossil Vaccinium is known from Siberia (Dorofeev, 1963), Poland (Lancucka-Srodoniowa, 1979) and Germany (Mai, 1965). Our material however is much larger than that described in the literature.

Ecology: Vaccinium is a genus of forest on acidic soil in the Northern Hemisphere with a preference for rather wet conditions. The absence of this species from autochthonous floras and the abundance in one allochthonous flora point to a habitat outside the wetland forest in the lower Rhenish basin. It is therefore considered a species of acidic coniferous forest and peatbog vegetations, unit 7 and 9 .

\section{EUCOMMIACEAE}

Eucommia europaea Mädler (Plate V, 6)

Material studied: Fruits; coll. no.8699-28: 1; 14141-23: 1; 14183-5: 2.

Remarks: Ca $20 \times 66 \mathrm{~mm}$ elliptical fruits with a "hairy" surface caused by numerous threads of latex. They are identified as E. europaea Mädler (1939).

Ecology: This species has only been found in allochthonous floras, which might point to a habitat outside the boggy vegetations. The ecology of the recent species and the very numerous finds in a Pleistocene river channel deposit at Tegelen suggest upland forest as the habitat, unit 6 .

\section{EUPHORBIACEAF}

Homalanthus costatus Mai

Material studied: Seeds; coll. no.7808-4: 11; 8295-15: 26; 8297-19: 1 ; 8300-21: 1 ; 8699-42: 1 ; 8700-40: 1 ; 13285-5: 52; 13286-6: 3 ; 13349-19: 1 ; 14139-4: 28 ; 14140-10: 11 ; 14141-27: 1 ;

\section{PLATE V}

1,2. Epacridicarpum mudense; no.8300-2; $25 \times$.

3,4. Vaccinium miocenicum; 3: Holotype, fruit, no.14141-24a; $12.5 \times$. 4: Paratype, seed; no. 14141-24b; $25 \times$

5. Sapium germanicum; no.8295-69; $12.5 \times$

6. Eucommia europaea; no.8699-28; $12.5 \times$.

7. Gaultheria procumbens; Recent; median cut through a fruit; $12.5 \times$ 
PLATE V
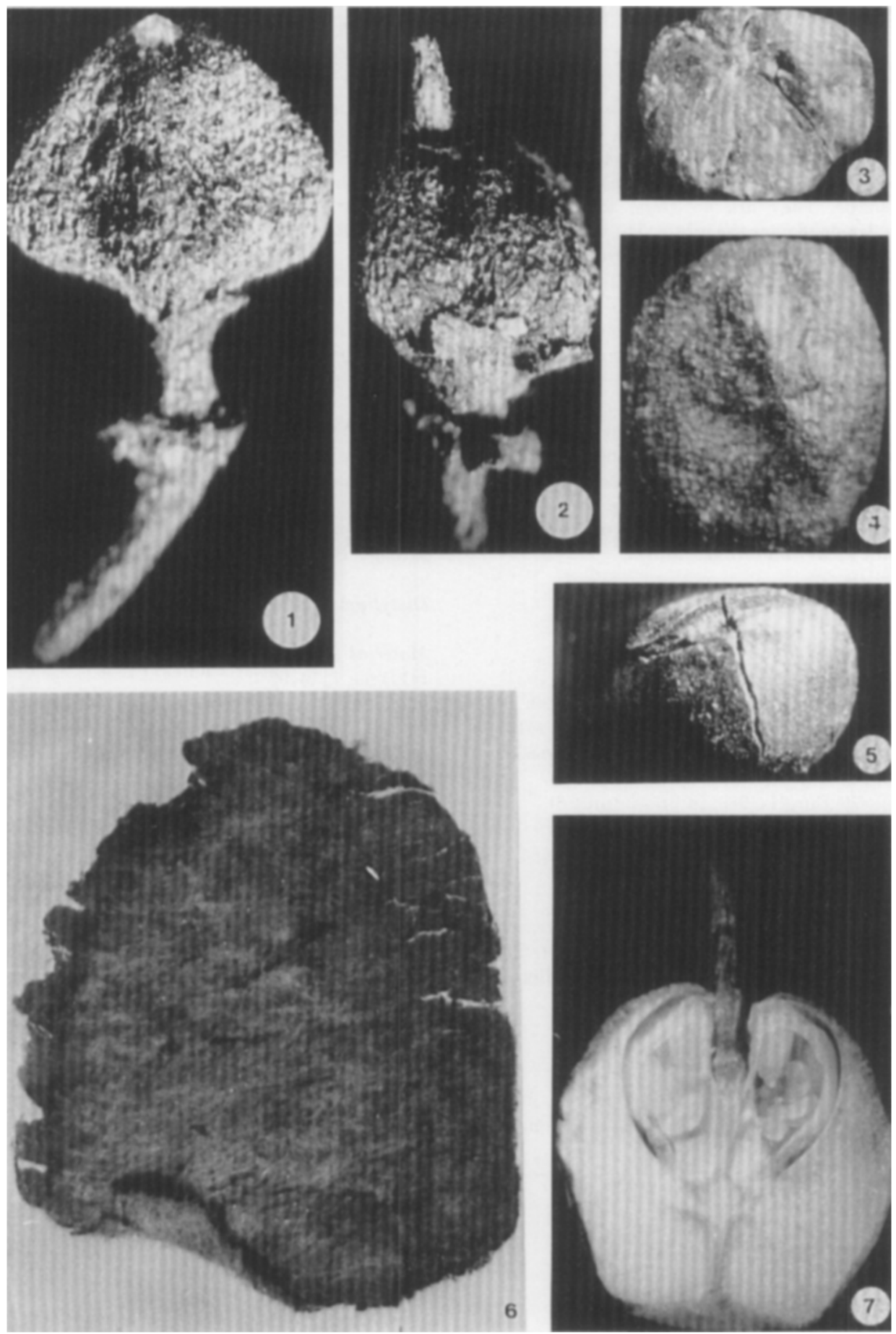
14142-1: $5 ; 14143-15: 6 ; 14145-6: 47 ; 14146-10: 5 ; 14399-2: 4$; 14400-2: 5; 14401-1: 2; 14402-1: 6 .

Ecology: See Van der Burgh (in press) (unit 3).

Sapium germanicum Kirchheimer (Plate V, 5; VI, 6)

Material studied: Seeds; coll. no.8295-69: 33; 8699-18: 16; 8700-18: 7.

Remarks: Most of the material is broken and deformed. Several seeds, however, are complete and have retained their original shape. They are $4 \times 3 \mathrm{~mm}$, lenticular to globose, slightly flattened near the hilum. The wall is black and consists of palisade-like slightly curved elongate sclerenchymatous cells; a thin endothelium-like endotesta is sometimes preserved. This material is similar to $S$ germanicum apart from the size, which is smaller. There is a fair similarity to recent $S$. sebiferum Roxburgh and to a lesser degree to $S$. japonicum Pax et Hoffman.

Ecology: Sapium has been found in lignite in Eastern Germany (Mai, 1964) and in lignite and clay in S. Germany (Gregor, 1980). Our finds are from allochthonous deposits from one open cast mine only and the percentages are very low. Therefore, despite its absence so far in the lignitic clays and lignite of the lower Rhenish basin, it is still considered a plant of wetland forest, unit 3 .

\section{FAGACEAE}

Fagus decurrens Reid et Reid

Material studied: Cupules; coll. no.7807-4: 1; 8295-30: 17; 8297-9: 5; 8699-4: 355; 8700-4: 63; 13286-1: 3; 13349-5: 1; 14141 17: $60 ; 14142-6$ : 3 ; 14145-30: $1 ; 14183-1$ : 5 . Nuts; coll. no.8699. 4: 110; 8700-4: 10; 14183-1: 12.

Ecology: See Van der Burgh (1983; in press) (unit 6).

Quercus robur $\mathrm{L}$.

Material studied: Cupules; coll. no.8297-10: 1.

Ecology: Quercus robur is considered part of the vegetations from units 5, 6 and 7 (Van der Burgh, 1983). The single find in an allochthonous flora is not in contradiction with this habitat.

Trigonobalanus exacantha Mai (Plate VI, 3)

Material studied: Cupules; coll. no.14142-26: 2 .

Remarks: These small, 4-6 $\times 3-4 \mathrm{~mm}$ three-valved cupules, of which the smaller contains remains of at least two triangular nuts are comparable to I. exacantha as described by Mai (1970a) and Gregor (1978a, 1980).

Ecology: This species of a genus of upland forest trees, both in America and Asia, has been found in allochthonous floras in S. Germany (Gregor, 1978a). Gregor (1980) reported it from a clay flora in which it might represent an allochthonous element. In our region it has been found in an allochthonous flora only. It is considered a plant of upland forest, unit 6 .

\section{GUNNERACEAE}

Proserpinaca reticulata Reid et Reid

Material studied: Fruits; coll. no.8295-14: 8; 14401-9: 1; 14429-6: 9.

Ecology: See Van der Burgh (1983, in press) (unit 3).

\section{HAMAMELIDACEAE}

Corylopsis urselensis Reid et Reid

Material studied: Seeds; coll. no.14401-22: 1; 14403-3: 2. Ecology: See Van der Burgh (in press) (units 3 and 9).

Distylium uralense Kolesnikova

Material studied: Seeds; coll. no.8295-50: 5; 13285-13: 11; 14141-43: 7; 14403-4: 2.

Ecology: See Van der Burgh (in press) (unit 3).

Liquidambar magniloculata Czeczott et Skirgiello (Plate VI, 2)

Material studied: Fruits; coll. no.8295-52: 4; 8699-10: 23; 8700-10: 2; 14139-27: 1; 14140-13: 1; 14141-21: 1; 14142-5: 2. Remarks: All fruits clearly belong to one species, but not every fruit shows the necessary characteristics for identification with the species described in the literature. Material from sample 8699 and 14139 however enabled me to reconstruct the shape of the endocarps, which was in accordance with that of L. magniloculata as depicted by Gregor (1978a).

Ecology: Liquidambar is known from a clay in Bavaria (Gregor, 1982). Our finds are only from allochthonous floras which points to a somewhat dry habitat inside the lower Rhenish basin, units 5 and 6 .

\section{PLATE VI}

1. Mastixia thomsonii; no.14145-5; $6 \times$.

2. Liquidambar magniloculata; no.14139.27; $6 \times$.

3. Trigonobalanus exacantha; no.14142-26; $12.5 \times$.

4. Tectocarya rhenana; no.14140-3, $1 \times$.

5. Teucrium sp.; no.14141-54; $25 \times$.

6. Sapium germanicum; no.8295-69; $12.5 \times$.

7. Menyanthes carpathica; no.8295-79;25 $\times$.

8. Sinomenium militzeri; no.8295-27; $12.5 \times$ 


\section{PLATE VI}
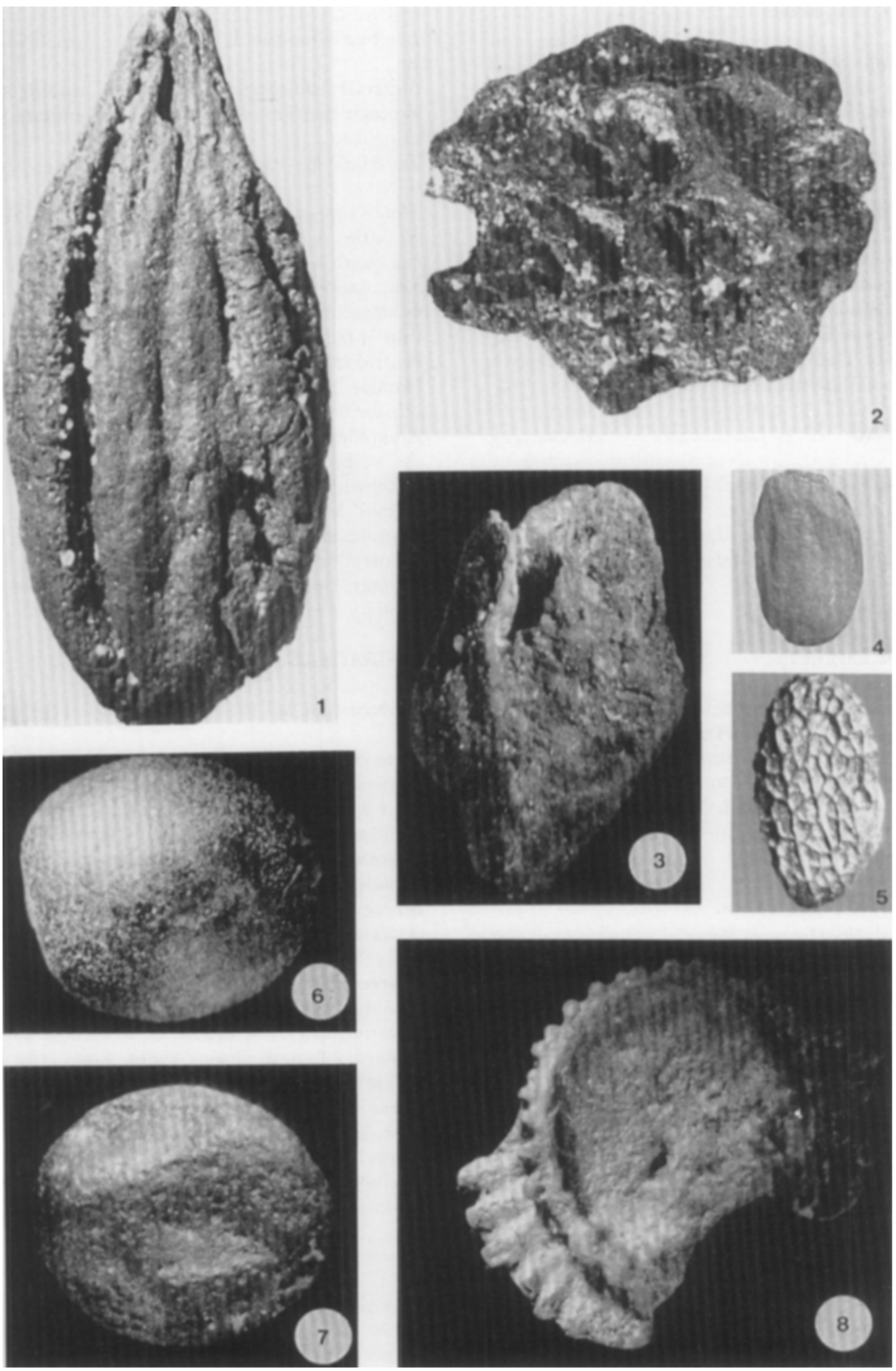


\section{HYPERICACEAE}

Hypericum holyi Friis (Plate IV, 7)

Material studied: Seeds; coll. no.7809-4: 87; 8295-47: 2; 14401-45: 2.

Ecology: See Van der Burgh (in press) (units 2 and 3).

Hypericum sp. (Plate IV, 8)

Material studied: Seeds; coll. no.14401-49: 1 .

Remarks: This $1.5 \times 0.6 \mathrm{~mm}$ seed with a distinct square cellular pattern is also determined as Hypericum. It differs from the preceding species in its greater length and less strongly developed longitudinal cell walls.

Ecology: Hypericum is a genus of plants growing in very different habitats. Therefore, nothing about the ecology of this seed from an allochthonous flora can be said.

\section{JUGLANDACEAE}

Carya ventricosa (Von Sternberg) Unger

Material studied: Endocarps; coll. no.7807-1: 4; 8295-68: 1 . Ecology: See Van der Burgh (in press) (unit 3).

Carya vel Juglans sp.

Material studied: Endocarps; coll. no.8295-84: 1; 14142-19: 1; 14145-29: 1 .

Remarks: Very small fragments; two of them are top fragments and one (14145-29) is a fragment of a thin walled endocarp with a narrow secondary ridge. It is therefore impossible to assign the fossils to anything more specific than a juglandaceous genus with large fruits (Mai, 1981). Ecology: Nothing concerning the ecology of these frag. mented material can be deduced.

Cyclocarya nucifera (Ludwig) Mai

Material studied: Endocarps; coll. no.8295-1: 2

Ecology: This species has only been found in an allochthonous flora; the recent species of the genus occur in upland forest, which agrees with the fossil find. C. nucifera is therefore considered a plant of upland forest, unit 6 .

Pterocarya limburgensis Reid et Reid

Material studied: Endocarps; coll. no.7807-20: 2; 8295-2: 5; 8297-14: 5 ; 8699-8: 23; 8700-8: 52; 13286-17: 1 ; 13349-9: 35; 14141-10: 81; 14142-7: 6; 14183-9: 6; 14428-2: 2 ; 14429-1: 9 . Ecology: See Van der Burgh (in press) (unit 3).

\section{LABIATAE}

\section{Ajuga antiqua Reid et Reid}

Material studied: Schizocarps; coll. no.8336-35: 1; 14183-22: 2. Ecology: This species has only been found in allochthonous floras. Recent Ajuga reptans, to which our species is closely related, is a plant of moist forests. A. antiqua is therefore considered to be a plant of flood plain forest, unit 5 .

Lycopus europaeus L.

Material studied: Schizocarps; coll. no.8700-42: 3 .

Ecology: See Van der Burgh (1983) (unit 2).

Teucrium sp. (Plate VI, 5; Plate VIII, 8)

Material studied: Schizocarps; coll. no.14141-54: 1.

Remarks: A $2.6 \times 1.6 \mathrm{~mm}$ dorsi-ventrally compressed schizocarp with a large circular contact area. The outer side is reticulate with basal longitudinal ridges, connected by anastomosing transversal ridges, at the top the reticulation is more or less isodiametric. The contact area has a central ridge ending in the apical half at the base of a style. Outside this ridge a reticulate pattern is present. This schizocarp is comparable with the Labiatae, subfamily Ajugoideae. Within this group there is a similarity with the schizocarps of the genus Teucrium. It cannot be matched with any of the living species and also the fossil species have a different shape, with the exception of T. elongatum, which however differs in size and ornamentation (Dorofeev, 1963).

Ecology: Nothing concerning the ecology of this species is known.

\section{LAURACEAE}

Laurocarpum sp. 1

Material studied: Endocarps; coll. no.8336-7: 2.

Remarks: Only the endocarps are preserved, they measure $5.0-6.0 \times 4.0-4.5 \mathrm{~mm}$, are compressed and slightly ovate to circular in outline. Although a similarity with fruits of Cinnamomum can be observed, it is impossible to identify them with this genus for the lack of cupules.

Ecology: Nothing is known about the ecology of this material.

\section{Laurocarpum sp. 2}

Material studied: Fruits; coll. no.14183-2: 1.

Remarks: Length $8 \mathrm{~mm}$, width $5 \mathrm{~mm}$; the fruit is compressed, the surface has a distinct lustre. At the base remains of a thickened pedicel and cupule are present. The fruit bears a certain resemblance to Ocotea rhenana Menzel. The material, however, is too incomplete to enable a reliable assignment to any genus within the Lauraceae. Ecology: The ecology of this material is unknown.

\section{Laurocarpum sp. 3}

Material studied: Endocarps; coll. no.14142-27: 1.

Remarks: This very incomplete fragment of an endocarp bears some resemblance to those of Persea sp. described by Van der Burgh (1978); however, it is smaller. Due to its incompleteness an identification is impossible. Ecology: The ecology of this material is unknown. 


\section{LORANTHACEAE}

Viscum sp.

Material studied: Fruits; coll. no.8297-26: 5; 8700-33: 1; 13349-7: 147; 14402-14: 1 .

Ecology: See Van der Burgh (in press) (unit 3).

\section{LYTHRACEAE}

Decodon globosus (Reid et Reid) Nikitin

Material studied: Seeds; coll. no.8297-27: 2; 8334-3: 1; 1334916 : 1 ; 14141-19: 13 ; 14183-27: 5 ; 14401-26: 2 ; 14428-9: 66; 14429 . 14: 49 .

Ecology: See Van der Burgh (in press) (unit 2).

Mneme menzelii (E.M. Reid) Eyde

Material studied: Seeds; coll. no.7807-27: 4; 8336-31: 2; 14141-7: 44; 14429-13: 154.

Ecology: See Van der Burgh (in press) (unit 2).

\section{MAGNOLIACEAE}

\section{Liriodendron geminatum Kirchheimer}

Material studied: Seeds; coll. no.7807-22: 4; 8295-16: 22; 8297-17: 23; 8335-16: 2 ; 8336-26: 12; 13286-31: 1 ; 14183-29: 46; 13349-18: 12; 14402-20: 1 .

Ecology: See Van der Burgh (in press) (units 3 and 5).

Magnolia burseracea (Menzel) Mai

Material studied: Seeds; coll. no.7807-3: 57; 7808-12: 8; 829518: 40 ; 8334-7: 1 ; 13285-6: 9 ; 13286-8: 1 ; 13349-1: 3 ; 14139: 1 ; 14140-11: 3 ; 14143-13: 1 ; 14145-4: 14; 14146-8: 1 ; 14183-6: 2 ; 14399-1: 8; 14428-14: 2.

Ecology: See Van der Burgh (in press) (unit 3).

Magnolia lignita (Unger) Mai

Material studied: Seeds; coll. no.7807-33: 2; 8295-83: 10; 14400-1: 6; 14402-2: 15.

Ecology: See Van der Burgh (in press) (unit 3).

\section{Magnolia lusatica Kirchheimer}

Material studied: Seeds; coll. no.7807-32: 3; 8295-82: 11; 13285-32: 2 ; 13349-26: 7 ; 14139-32: 8; 14140-32: 4; 14143-27: 3 ; 14145-33; 13.

Ecology: See Van der Burgh (in press) (unit 3).

Magnolia sp.

Material studied: Seeds; coll. no.7807-5: 72; 14142-17: 1; 14402-15: 2.

Ecology: See Van der Burgh (in press) (unit 3).

\section{MASTIXIACEAE}

Eomastixia persicoides (Unger) Mai

Material studied: Endocarps; coll. no.7807-2: 7; 8295-34: 32; 8699-22: 1; 14139-24: 2 ; 14140-2: 8; 14143-8: 1; 14145-21: 3; 14146-17: 2 ; 14402-3: 3.

Ecology: See Van der Burgh (in press) (unit 3).

Mastixia thomsonii Mai (Plate VI, 1)

Material studied: Endocarps; coll. no.8295-33: 127; 8699-21: 5; 13285-1: 25; 14140-5: 4; 14143-10: 11; 14145-5: 16; 14402-19: 1 . Remarks: These $10-22 \mathrm{~mm}$ long and $6-10 \mathrm{~mm}$ wide oval endocarps have a narrow germination pore and operculum. They bear, especially at the base, ridges, but these may be absent at the blunt apex. The endocarps are very variable in shape and size. This material is similar to $M$. thomsonii as described by Mai (1970c).

Ecology: See Van der Burgh (in press) (units 3 and 5).

Tectocarya rhenana Kirchheimer (Plate VI, 4)

Material studied: Fruits; coll. no.8295-35: 1; 8699-23: 1; 14140-3: 5; 14143-9: 2.

Remarks: Large fruits, $32-46 \times 20-28 \mathrm{~mm}$, with a smooth surface. At the base there is a large, sometimes conical hilum (12 $\mathrm{mm}$ diameter), while at the apex a narrow groove is present. This material is similar to that described by Kirchheimer $(1934 a$, b) as $T$. rhenana.

Ecology: Mai (1964) reported the genus from clay and lignite next to sandy deposits. Such occurrences are unknown in our area; all our finds are in allochthonous floras, where it is found in small quantities. It is considered a plant of wetland forest and floodplain forest, units 3 and 5 .

\section{MENISPERMACEAE}

Sinomenium militzeri Kirchheimer (Plate VI, 8)

Material studied: Seeds; coll. no.8295-27: 3; 14141-28: 1; 14183-8: 1.

Remarks: More or less circular campylotropous seeds with dentate ridges on the outer side. They measure 3.9-6.4 $\times$ $3.2-5.1 \mathrm{~mm}$. The inner surface is glossy. They are identical to $S$. militzeri, as described by Kirchheimer (1943).

Ecology: This species has been found in allochthonous floras in very small numbers. The present-day habitat of this genus of vines is moist forest and thickets. It is therefore supposed to be a plant of floodplain forest and forest border and scrub vegetation, units 4 and 5 .

\section{MENYANTHACEAE}

Menyanthes carpathica Jentys-Szaferowa et Truchanowiczowa (Plate VI, 7)

Material described: Seeds; coll. no.8295-79: 3 .

Remarks: Small, ca $1.5 \mathrm{~mm}$ diameter circular seeds with a 
glossy surface and $0.2 \mathrm{~mm}$ thick walls. The cellular structure of the wall is as described by Truchanowiczowa (1964) for M. carpathica.

Ecology: This typical shore and swamp plant has only been found in an allochthonous flora; this is however quite normal for plants of these habitats; unit 2 .

\section{MYRICACEAE}

Comptonia costata Dorofeev

Material studied: Endocarps; coll. no.13285-28: 1.

Ecology: Recent Comptonia is a plant of moist to dry heath. The occurrence of a single endocarp in an allochthonous flora is in agreement with this, unit 8 .

\section{Myrica boveyana (Heer) Chandler}

Material studied: Endocarps; coll. no.7808-19: 11; 14401-11: 1; 14403-2: 26.

Ecology: See Van der Burgh (in press) (units 3 and 9).

\section{Myrica ceriferiformis Kownas}

Material studied: Endocarps; coll. no.7807-19: 52; 7808-20: 16; 7809-1: $2171 ; 8335-1$; 4 8336-10: $2 ; 8699-11$ : 30; 14399-11: $51 ; 14400-6: 4 ; 14402-16: 10 ; 14403-8: 2$.

Ecology: See Van der Burgh (in press) (unit 3).

\section{Myrica minima Negru}

Material studied: Endocarps; coll. no.7807-17: 171; 7808-17: 33; 7809-5: 98; 8295-46: 7500; 8335-8: 1; 8699-5: 369; 8700-5: 129; 13285-29: 1 ; 14139-18: 3 ; 14141-26: 35 ; 14142-13: 2 ; 14145-8: 41 ; 14146-6: 2 ; 14399-12: 15; 14400-7: 3 ; 14402-17: 54. Ecology: See Van der Burgh (in press) (unit 3).

\section{cf. Myrica sp.}

Material studied: Endocarps; coll. no.13286-25: 3; 14141-33: 2.

Remarks: Compressed circular apotropous endocarps, $2.22 .5 \mathrm{~mm}$ in diameter. No remains of a pericarp have been found. They are tentatively assigned to Myrica.

Ecology: The ecology of this material is unknown, but it may not differ very much from that of the other species of Myrica. It has been placed in units 3 and 9 .

Myrica suppanii Kirchheimer
Material studied: Endocarps; coll. no.7807-18: 7; 8295-28: 2; 14139-5: 1 ; 14142-12: 1 ; 14145-26: 2 ; 14401-8: 1 ; 14403-1: 58; 14428-12: 1 .

Ecology: See Van der Burgh (in press) (units 3 and 9).

\section{NYMPHAEACEAE}

Brasenia victoriae (Caspary) Weberbauer.

Material studied: Seeds; coll. no.8295-11: 20; 14401-4: 2 . Ecology: This plant has only been found in allochthonous floras. It is therefore considered a plant of open water, especially in not too muddy circumstances, unit 1 .

Nymphaea alba L. (Plate VII, 1)

Material studied: Seeds; coll. no.14428.7: 3.

Remarks: Small, 1.5 $2.2 \times 1.11 .6 \mathrm{~mm}$, black oval seeds with a glossy surface and a distinct, transversely slightly elongated cellular pattern. The raphe is difficult to observe. Moreover, the germination pore (with operculum) is not very clearly marked. All these features are known from the recent $N$. alba to which the fossil material has been assigned.

Ecology: Nymphaea is a genus of open water vegetation and can be expected at all places where sediments have been accumulated on the bottom, unit 1 .

Nymphaea sp.

Material studied: Seeds; coll. no.8336-32: 1 .

Remarks: A fragment of a seed of the Nymphaeaceae. The length was ca. $4.4 \mathrm{~mm}$, the width is unknown, the surface bears a distinct cellular pattern with very low elevated cells. It has been assigned to Nymphaea.

Ecology: See N. alba.

Pseudoeuryale europaea (Reid et Reid) Dorofeev (Plate VII, $2,3,4)$

Material studied: Seeds; coll. no.8295-43: 1; 14141-45: 2: 14428-5: 5 .

Remarks: Compressed, dark brown seeds, 4.6 $6.3 \times 3.7$ $4.8 \mathrm{~mm}$. The walls are covered with elongate curved cells; the operculum of the germination pore contains only the micropyle and not the hilum. The material is similar to P. europaea, as described by Reid and Reid (as Euryale europaea) (1907), Mai (1973) and Dorofeev (1972) except for the dimensions which are smaller in the present material.

\section{PLATE VII}

1. Nymphaea alba; no.14428-7; $25 \times$.

2,3,4. Pseudoeuryale europaea; no.14428-5; 2,4: $25 \times ; 3: 12.5 \times$

5. Paliurus sibiricus; no.8297-23; $12.5 \times$.

6,9. Nyssa ornithobroma; 9 with germination pore and valve; 6 : no.8295-44; 9 ; no.14141-26; $6 \times$.

7. Crataegus angusticarpa; no.8700-16; $12.5 \times$.

8. Rehderodendron ehrenbergii; no.8295-29; $1 \times$. 
PLATE VII
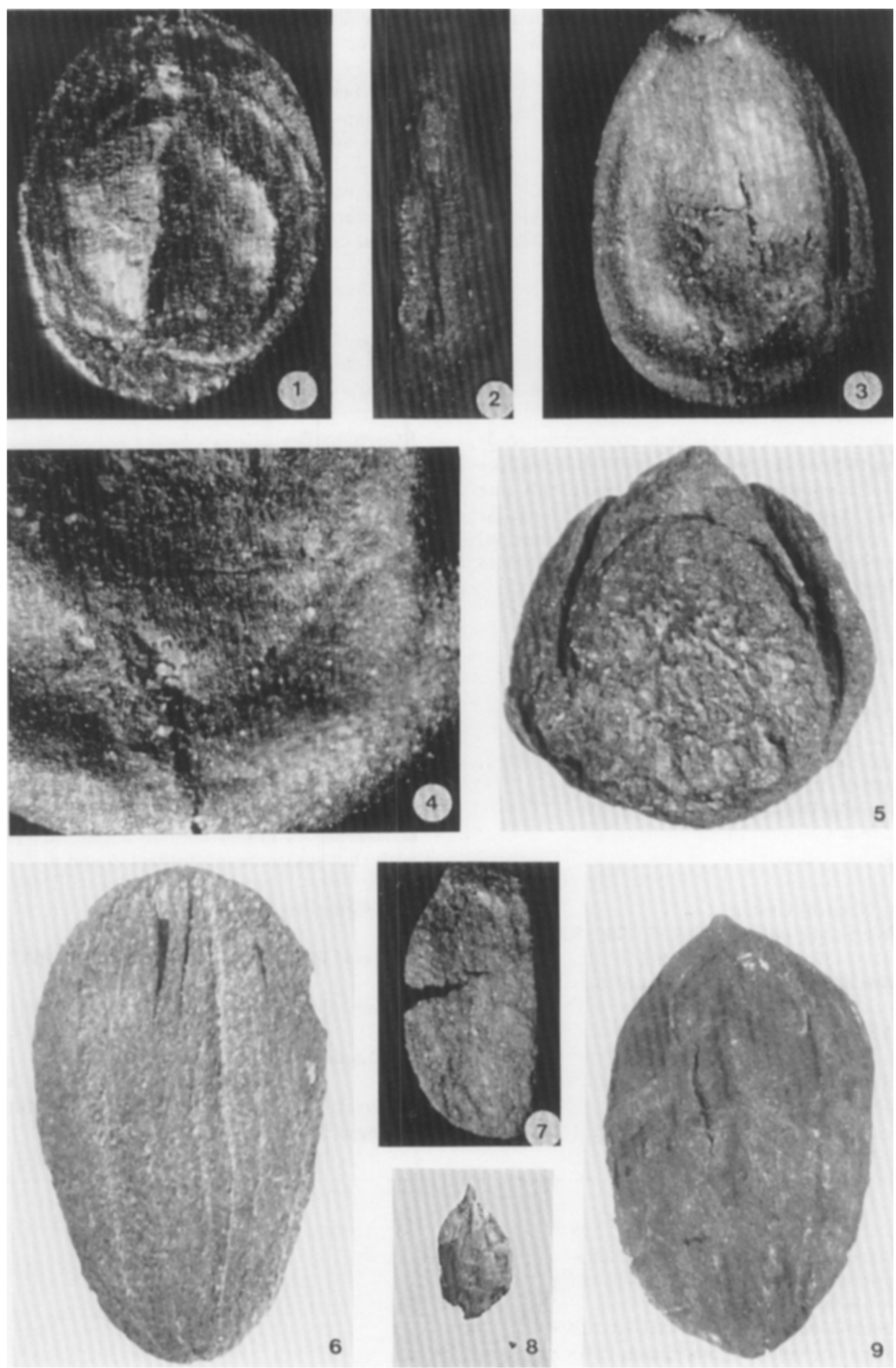
Ecology: Mai (1964) reported the species from a lignite. Our material has been found in a silt (semiautochthonous flora) and in sand (allochthonous floras). It is a member of a typical family of waterplants which agrees with its occurrences, unit 1.

\section{NYSSACEAE}

\section{Nyssa disseminata Kirchheimer}

Material studied: Endocarps; coll. no.8295-3: 3; 8336-2: 1; 8699-34: 1 ; 13286-9: 1 ; 13349-14: 2; 14139-11: 3; 14140-20: 3; 14142-25: $1 ; 14146-9: 1 ; 14429-4: 3$.

Ecology: See Van der Burgh (in press) (unit 3).

Nyssa ornithobroma Unger (Plate VII, 6, 9)

Material studied: Endocarps; coll. no.8295-14: 5; 8699-20: 5; 8700-20: 21 ; 13349-10: 2 ; 14141-16: 15 .

Remarks: The large 9.5-15.5 × 3.7-8.2 mm compressed seeds bear 10-16 longitudinal grooves and ridges. Their outline is oblong-ovate to obovate; most of them have only one locule. The germination pores are covered by triangular opercula. The walls are fairly thin $(0.1 \mathrm{~mm})$. This material is very similar to that described as $N$. ornithobroma by Mai and Gregor (1982).

Ecology: See Van der Burgh (in press) (unit 3).

\section{OLEACEAE}

\section{Chionanthus ruehlii Gregor}

Material studied: Endocarps; coll. no.7807-26: 6; 13286-29: 1; 14399-17: 5; 14402-25: 3.

Ecology: See Van der Burgh (in press) (unit 3).

\section{PUNICACEAE}

Punica natans (Nikitin) Gregor

Material studied: Seeds; coll. no.8295-37: 1790; 8699-9: 128; 8700-41: 1; 14141-32: 37; 14401-25: 9; 14402-10: 10.

Ecology: See Van der Burgh (in press) (unit 6).

\section{RHAMNACEAE}

Paliurus sibiricus Dorofeev (Plate VII, 5)

Material studied: Endocarps; coll. no.8297-23: 1; 14141-53: 9.
Remarks: These 4-5 mm three-locular fruits with three valves over the germination pores are identical to the material described by Dorofeev (1963) from Western Siberia.

Ecology: Gregor (1978a, 1980, 1982, 1983) mentioned Paliurus from allochthonous and autochthonous floras in $\mathrm{S}$. Germany and Greece. Our finds are from allochthonous foras only. The recent $P$. ramosissimus with which the species is comparable occurs in upland forests in the warmer parts of Japan, Taiwan and the mainland of Asia. Therefore $P$. sibiricus is considered a plant of upland forest, unit 6 .

Ziziphus striata (Ludwig) Mai et Gregor

Material studied: Fruits; coll. no.8335-25: 1; 14142-20: 1; 14402-22: 1.

Ecology: See Van der Burgh (in press) (unit 3).

\section{ROSACEAE}

Crataegus angusticarpa Reid (Plate VII, 7; Plate VIII, 1, 2)

Material studied: Endocarps; coll. no.8699-38: 9; 8700-16: 20; 14141-31: 1 ; 14142-18: 1 .

Remarks: These endocarps are triangular in cross section and sometimes bear a vein on the outer (dorsal) side. They are proximally fused, in the upper quarter completely free, being slimly covered by a glossy epidermis which extends to one quarter of the ventral side at most and covers the apex. The apex is slightly constricted. They measure $3.2-4.5 \times 1.3-2.0 \mathrm{~mm}$. This material is similar to C. angusticarpa as described by Reid (1923).

Ecology: The extant species of this genus are found in moist to dry locations, especially shrub and upland forest. The occurrence in allochthonous floras only is in agreement with this environment, units 4,5 and 6 .

Crataegus jonkeri Van der Burgh

Material studied: Endocarps; coll. no.8700-38: 24; 14141-34: 1.

Ecology: See the preceding species.

Crataegus nodulosa Reid

Material studied: Endocarps; coll. no.8297-31: 1; 8335-18: 4. Ecology: See C. angusticarpa.

\section{PLATE VIII}

1,2. Crataegus angusticarpa; no.8700-16; $12.5 \times$

3,7. Zanthoxylum ailanthiforme; no.8295-8; $12.5 \times$

4. Solanum nigrum; no.14183-28; $25 \times$.

5. Phellodendron lusaticum; no.14141-12; $12.5 \times$.

6. Toddalia naviculaeformis; no.8295-7; $12.5 \times$.

8. Teucrium sp.; ventral face; no.14141-54; $25 \times$.

9,11. Staphylea bessarabica; 9 : outer surface; 11: inner surface, raphesinus; no.8295-8; $12.5 \times$.

10. Meliosma wetteraviensis; no.8297-22; $12.5 \times$. 


\section{PLATE VIII}
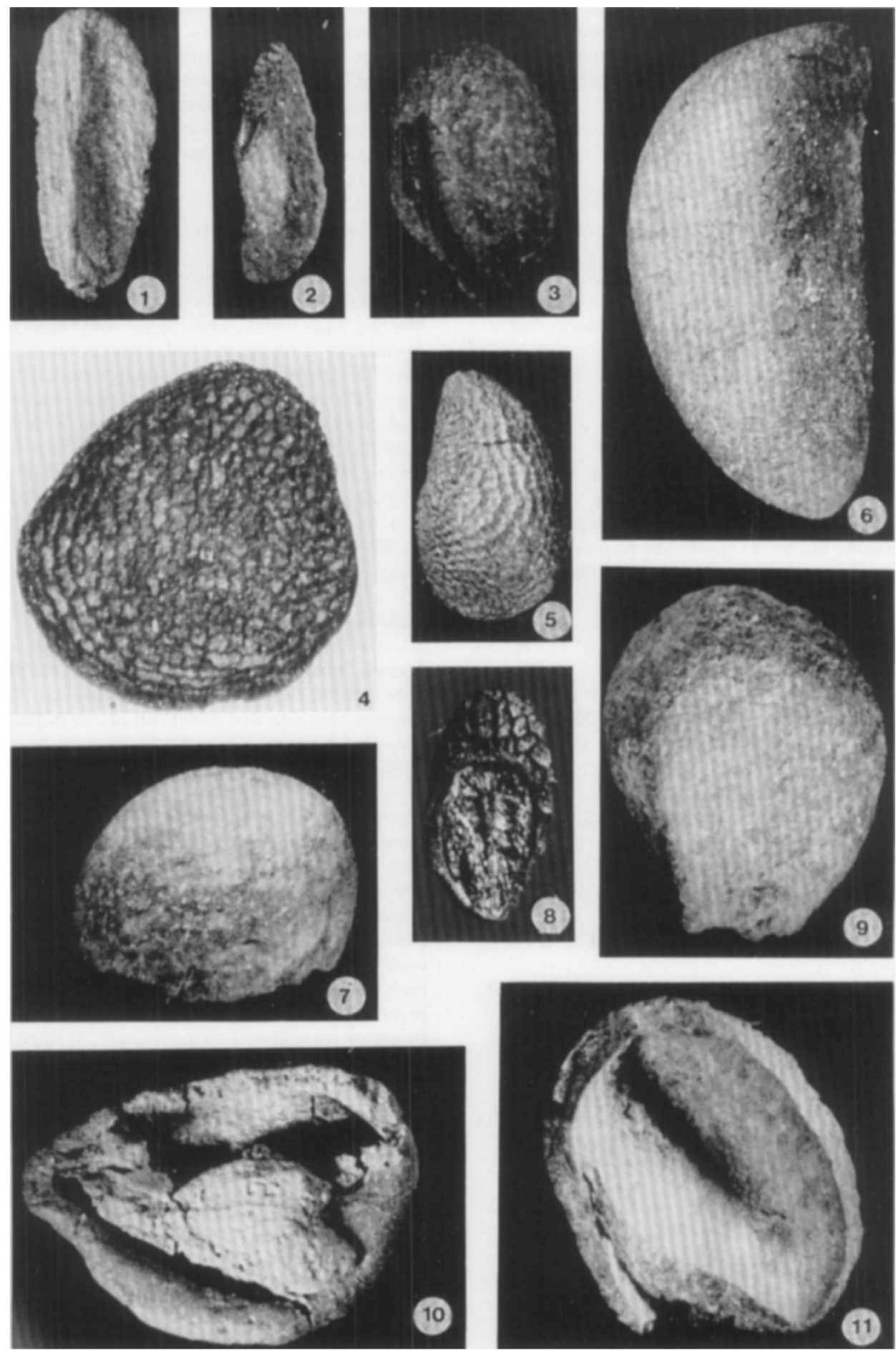


\section{Crataegus sp. 1}

Material studied: Endocarps; coll. no.8336-12: 1.

Remarks: This $4.8 \times 2.7 \mathrm{~mm}$ endocarp bears a central vein on the dorsal side, it is contracted at the free apex and has traces of an epidermis-covered triangular lateral field. It is not possible to assign it to any known species.

Ecology: See C. angusticarpa.

\section{Crataegus sp. 2}

Material studied: Endocarps; coll. no.8297-34: 1; 8700-45: 4. Remarks: Deformed, 4.2-5.5 $\times 1.9-3.0 \mathrm{~mm}$ endocarps with remains of a ventral ridge, a "hilum" and a free apex. The lateral faces are smooth, the dorsal one is rough. This material can be identified as belonging to Crataegus, but a further determination is impossible.

Ecology: See C. angusticarpa.

Crataegus sp. 3

Material studied: Endocarps; coll. no.8700-44: 2.

Remarks: These fragmented endocarps measure $3.1-3.3 \times 1.8-2.0 \mathrm{~mm}$. The dorsal side bears longitudinal nodular outgrowths, the lateral faces show remnants of a free apex. It has provisionally been assigned to Crataegus. Ecology: See C. angusticarpa.

\section{Rubus laticostatus Kirchheimer}

Material studied: Endocarps; coll. no.7807-10: 17; 7808-3: 25; 8295-9: 20; 8297-21: 1; 8335-2: 1; 8699-19: 4; 8700-19: 106; 13285-18: 1 ; 13286-26: 2 ; 13349-11: 1 ; 14139-17: 2 ; 14140-27: 5 ; 14141-1: 80; 14146-5: 11; 14183-32: 8; 14399-13: 12; 14400-16: 9 ; 14402-8: 6; 14428-10: 5 .

Ecology: See Van der Burgh (in press) (units 3, 4, 5, 6, 7 and 8).

\section{Sorbus aria Crantz}

Material studied: Seeds; coll. no.8295-85: 1; 8297-33: 1; 833633: 1 .

Ecology: At present, this is a plant of upland forest. This agrees with the finds in allochthonous floras, unit 6 .

\section{Sorbus herzogenrathensis (Menzel) Gregor}

Material studied: Endocarps; coll. no.7807-16: 2; 7808-7: 519; 14399.7: 7; 14402-9: 7 .

Ecology: See Van der Burgh (in press) (unit 3).

\section{RUTACEAE}

Phellodendron lusaticum Kirchheimer (Plate VIII, 5)

Material studied: Seeds; coll. no.14139-15: 2 ; 14145-12: 3 . Remarks: These seeds measure 3.5-3.8 $\times 2.0-2.3 \mathrm{~mm}$. They are black and bear a reticulate ornamentation. The testa is composed of sclerenchymatous isodiametric cells; in addition along the ventral side an inner layer of palisade cells is present. These seeds are smaller and with less sharp ornamentation ridges than those of $P$. elegans (Reid and Reid, 1915). They are similar to P. lusatica described by Kirchheimer (1940).

Ecology: This species has only been found in allochthonous floras. Gregor (1980) recorded it from a clay in which some allochthonous elements are present. The genus occurs in upland forest in the present day, which is in accordance with the recorded occurrence of the fossil material, unit 6 .

Toddalia naviculaeformis (Reid) Gregor (Plate VIII, 6)

Material studied: Seeds; coll. no.8295-7: 24.

Remarks: The length is $5.5-7.2 \mathrm{~mm}$, the width $3.0-3.9 \mathrm{~mm}$. The seeds are black, anatropous and thick-walled, with a straight or concave ventral surface and a curved dorsal side. The outer surface is smooth or with low rounded warts. The walls are composed of isodiametric cells. These seeds are similar to material described from France by Reid (1923) (as Martya naviculaeformis) and from S. Germany by Gregor (1978b) as Toddalia naviculaeformis.

Ecology: Gregor (1983) recorded this species from a lignite in Aliveri, Greece. In our region it has only been found in an allochthonous flora. It is considered a bottomland plant, growing in wetland forest, unit 3 .

\section{Toddalia rhenana Gregor}

Material studied: Seeds; coll. no.7807-8: 5; 7808-5: 1; 7809-2: 5; 8295-6: 14; 13286-19: 1; 14142-9: 4.

Ecology: See Van der Burgh (in press) (unit 3).

Zanthoxylum ailanthiforme (Gregor) Gregor (Plate VIII, 3, 7)

Material studied: Seeds; coll. no. 8295-8: 13.

Remarks: $4.0-5.0 \times 3.0-3.5 \mathrm{~mm}$, black anatropous seeds with a more or less reticulate ornamentation consisting of low rounded ridges and grooves. They are similar to material described by Gregor (1978b) from Bavaria

Ecology: Gregor $(1980,1982)$ recorded the genus from some autochthonous floras in southern Germany. In our region it has been found only in allochthonous floras. The recent equivalent forms part of a moist forest and it is therefore considered to have been a plant of floodplain forest, unit 5 .

\section{SABIACEAE}

Meliosma wetteraviensis (Ludwig) Mai (Plate VIII, 10)

Material studied: Seeds; coll. no.8297-22: 2; 8700-15: 1. Remarks: Black, 5-6 $\times 4-5 \mathrm{~mm}$, more or less triangular seeds with a large lighter-coloured hilum. They are similar to $M$. wetteraviensis as described by Mai (1973).

Ecology: Although our material has only been found in allochthonous floras, this and related species have been reported from autochthonous floras in Bavaria (Gregor, $1980,1982)$. It is therefore considered to be a plant of the wetland forest, unit 3 . 


\section{SOLANACEAE}

Solanum nigrum L. (Plate VIII, 4)

Material studied: Seeds; coll. no.14183-28: 3.

Remarks: These are campylotropous seeds with a diameter of about $1.5 \mathrm{~mm}$. The outline is more or less circular, the surface bears a reticulate sculpture. The seeds are identical to those of the recent $S$. nigrum $\mathrm{L}$.

Ecology: S. nigrum is a plant of herbaceous vegetations on fertile soils, which develop after serious disturbance of the original vegetation, unit 2 .

\section{STAPHYLEACEAE}

\section{Staphylea bessarabica Negru (Plate VIII, 9, 11)}

Material studied: Seeds; coll. no.8295-5: 3; 14142-16: 5; 14145-27: 1 seed.

Remarks: These are 5-6 $\times 4-5 \mathrm{~mm}$ anatropous seeds with the micropyle at the extremity of a conspicuous basal rim. The sinus of the raphe lies within a less distinct rim. The surface shows a fine isodiametric cellular pattern. These seeds are similar to S. bessarabica (Negru, 1972).

Ecology: Staphylea has only been found in allochthonous floras, which suggests a habitat either in the floodplain forest or the upland forest and forest border vegetation. Its occurrence in a clay together with other extra-local elements (Gregor, 1980) is in accordance with this assumption of a somewhat drier habitat, units 4,5 and 6 .

\section{Staphylea sp.}

Material studied: Seeds; coll. no.14183-13: 1

Remarks: This is a markedly compressed seed which could not be identified at a more precise level than that of the genus.

Ecology: This seed may tentatively be placed in the same units as the preceding species, i.e. units 4,5 and 6 .

\section{STYRACACEAE}

\section{Halesia crassa (Reid et Reid) Kirchheimer}

Material studied: Endocarps; coll. no.8295-31: 156; 8336-8: 1; 8699-26: 5; 14140-14: 1; 14142-8: 4 .

Ecology: This species has only been found in allochthonous floras. Recent Halesia occurs in upland forest and wetland forest. The presence in allochthonous floras is not in contradiction with this environment. However, its absence from autochthonous floras contradicts with wetland forest. Therefore $\boldsymbol{H}$. crassa is considered to be a plant of upland forest only, unit 6 .

\section{Rehderodendron ehrenbergii (Kirchheimer) Mai (Plate VII,} 8)

Material studied: Fruits, endocarps; coll. no.8295-29: 7. Remarks: The endocarps, $14-24 \times 5-17 \mathrm{~mm}$, bear sharp, sometimes divaricating ridges. They are partly covered by mesocarp and exocarp. At the apex of the more complete fruits is a conical discus. When this is broken off, one to three pores are visible. This material is similar to that described under the name Durania ehrenbergii by Kirchheimer (1936) and redescribed under the present name by Mai (1970a,b).

Ecology: So far, R. ehrenbergii has only been found in allochthonous floras. Therefore this woody plant is considered as a member of forest vegetation, including floodplain forest, upland forest and forest border-scrub, units 4,5 and 6 .

\section{Styrax maximus (Weber) Kirchheimer}

Material studied: Seeds; coll. no.8295-19: 5; 8297-32: 1; 14141-29: 1; 14183-7: 1.

Ecology: Styrax has only been found in allochthonous floras, suggesting a rather dry habitat. Extant members of the genus occur either in wetland forest or upland forest. The absence from autochthonous floras points to a drier habitat, unit 6 .

\section{SYMPLOCACEAE}

\section{Symplocos germanica Mai}

Material studied: Endocarps; coll. no.7808-11: 20; 8295-59: 2; 8297-28: 1 ; 8699-15: 1; 8700-34: 1 ; 13285-7: 46; 13286-4: 1 ; 14140-24: 44; 14143-19: 4; 14145-24: 4; 14146-13: 9; 14399-8: 11; 14400-8: 1 ; 14402-6: 11.

Ecology: See Van der Burgh (in press) (unit 3).

Symplocos gothanii Kirchheimer

Material studied: Endocarps; coll. no.7808-28: 79; 8295-60: 55; 8699-12: 15; 8700-12: 50; 14139-9: 27; 14142-23: 5; 14399-10: 38; 14400-9: 16; 14402-7: 13.

Ecology: See Van der Burgh (in press) (unit 3).

Symplocos lignitarum (Quenstedt) Kirchheimer

Material studied: Endocarps; coll. no.7807-31: 1; 7808-10: 9; 8295-62: 4159; 8297-12: 10; 8335-14: 1; 8336-3: 2; 8699-13: 40; 8700-13: 24 ; 13285-9: 33; 13286-5: 9; 14139-8: 4; 14140-22: 954; 14141-3: 11; 14142-22: 5; 14143-17: 111; 14145-15: 11; 14146-15: 269; 14399-9: 2; 14400-10: 1; 14402-28: 7 .

Ecology: See Van der Burgh (in press) (units 3 and 5).

Symplocos minutula (Von Sternberg) Kirchheimer (Plate IX, 1)

Material studied: Endocarps; coll. no.8295-57: 20; 8335-23: 1; 13286-1: 1.

Remarks: These 4.8-9.5 $\times 3.5-5.0 \mathrm{~mm}$ endocarps are smooth or with numerous low ribs. The ribs merge into longitudinal rows of small tubercles. At the constricted base a circular groove with two or three pores is present. Although in most cases all the locules of the endocarp are fertile and well developed, these endocarps are comparable with $S$. minutula as described by Kirchheimer (1949). 
Ecology: This species is known from Salzhausen where it occurs in rather large numbers in the carpolitic lignite. In our region it has been found only in low numbers in allochthonous floras. Based on the low numbers and the occurrence in Salzhausen it is considered a plant of wetland forest, unit 3 .

\section{Symplocos pseudogregaria Kirchheimer (Plate IX, 4, 6)}

Material studied: Endocarps; coll. no.8295-58: 2; 13286-24: 2; 14140-23: 162; 14143-18: 20; 14145-10: 22; 14146-14: 73; 14401 2: 1 .

Remarks: These endocarps measure $4.5-7.0 \times 3.0-4.0 \mathrm{~mm}$. The surface is covered by short longitudinal and oblique ridges and grooves. The endocarps are trilocular, the groove at the base is shallow with three pores. This material is similar to $S$. pseudogregaria as described by Kirchheimer (1938, 1949).

Ecology: Gregor (1980, 1982) reports this species from autochthonous floras in $\mathrm{S}$. Germany. In our region we only have found it in allochthonous floras with occasionally high percentages, suggesting a drier habitat. It is therefore considered a plant of various environments, including wetland forest, but with a preference for the floodplain forest, (units 3 and 5).

\section{Symplocos salzhausenensis (Ludwig) Kirchheimer}

Material studied: Endocarps; coll. no.7808-8: 9; 8295-61: 106; 8297-11: 1; 8300-10; 4; 8335-13: 1; 8699-14: 2; 8700-14: 12; 13285-8: 1 ; 14143-21: 1 ; 14145-11: 1 ; 14146-11: 4; 14402-27: 18. Ecology: See Van der Burgh (in press) (unit 3).

\section{Symplocos schereri Kirchheimer}

Material studied: Endocarps; coll. no.7808-8: 1; 8295-22: 26; 8297-13: 2 ; 8336-1: 1 ; 8699-16: 2 ; 13286-2: 1; 14139-7: 6; 1414012: 8 ; 14143-20: 3 ; 14145-23: 3 ; 14146-12: 3 .

Ecology: See Van der Burgh (in press) (units 5 and 6 ).

\section{THEACEAE}

Eurya lusatica Mai (Plate IX, 5)

Material studied: Seeds; coll. no.8300-7: 14.

Remarks: These are $2-2.5 \mathrm{~mm}$, circular or slightly elongate campylotropous flat black seeds with a very characteristic reticulate sculpture on the surface. These seeds are larger than those of E. stigmosa and are similar to E. lusatica as described by Mai (1971).
Ecology: Mai (1964) and Gregor (1980) reported this species from autochthonous floras only. However, it can be found as an allochthonous fossil too, unit 3 .

\section{Eurya stigmosa Mai}

Material studied: Seeds; coll. no.7807-9: 1; 7808-1: 680; 829510: 147; 8297-8: 5; 8300-11: 26; 8335-5: 22; 8336-11: 17; 8699-7: 17 ; 8700-39: 2 ; 13285-15: 7 ; 13286-18: 1 ; 14139-21: 15 ; 14140-15: 17 ; 14141-18: 11 ; 14142-14: 1 ; 14143-16: 5 ; 14145-16: 16; 1414620: 23 ; 14183-16: 6 ; 14399-16: 575; 14400-11: $581 ; 14401-24: 1$; 14402-18: 347; 14403-7: 1 .

Ecology: See Van der Burgh (in press) (unit 3).

Polyspora lignitica (Menzel) Gregor (Plate IX, 3)

Material studied: Capsules; coll. no.8699-43: 1; 14183-14: 1. Remarks: These are parts of loculicide capsules, $22 \mathrm{~mm}$ long and $7 \mathrm{~mm}$ wide. There is a similarity to the fruit Polyspora lignitica, as described by Gregor (1984).

Ecology: Polyspora is a plant of forests outside the direct influence of the rivers, i.e. upland forest. Our find in allochthonous floras is in accordance with this environment, unit 6.

Stewartia beckeriana Kirchheimer

Material studied: Capsules; coll. no.8699-27: 2; 8700-22: 1; 13285-16: 1.

Ecology: Stewartia is considered an upland forest plant (Van der Burgh, 1983) which agrees with its occurrence in allochthonous floras, unit 6 .

\section{TRAPACEAE}

Trapa heerii Fritsch (Plate IX, 2, 7)

Trapa sp. in: Van der Burgh (in press)

Material studied: Fruits; coll. no.8295-56: 1; 13349-21: 5; 14428-3: 20.

Remarks: The fruits are very variable in size, the height ranging from $6-8 \mathrm{~mm}$, the width (with spines) from 8-20 mm. The fruit bears two pairs of spines; a lower pair of small spines and an upper pair of long spines. Most fruits are much wider than long. These characteristics are known from $T$. heerii, $T$. irtyshensis and T. natans. $T$. natans however is too large and in $T$. irtyshensis the variability in size is smaller (Dorofeev, 1963), so our material resembles closely $T$. heerii. In sample 14428 numerous spinetips with small dents also occur. Ecology: See Van der Burgh (in press) (unit 1).

\section{PLATE IX}

1. Symplocos minutula; no.8295-27; $12.5 \times$.

2,7. Trapa heerii; no.14428-3; $2: 12.5 \times ; 7: 6 \times$

3. Polyspora lignitica; no.14183-14; $6 \times$.

4,6. Symplocos pseudogregaria; no.14140-23; $12.5 \times$.

5. Eurya lusatica; no.8300-7; $25 \times$. 


\section{PLATE IX}
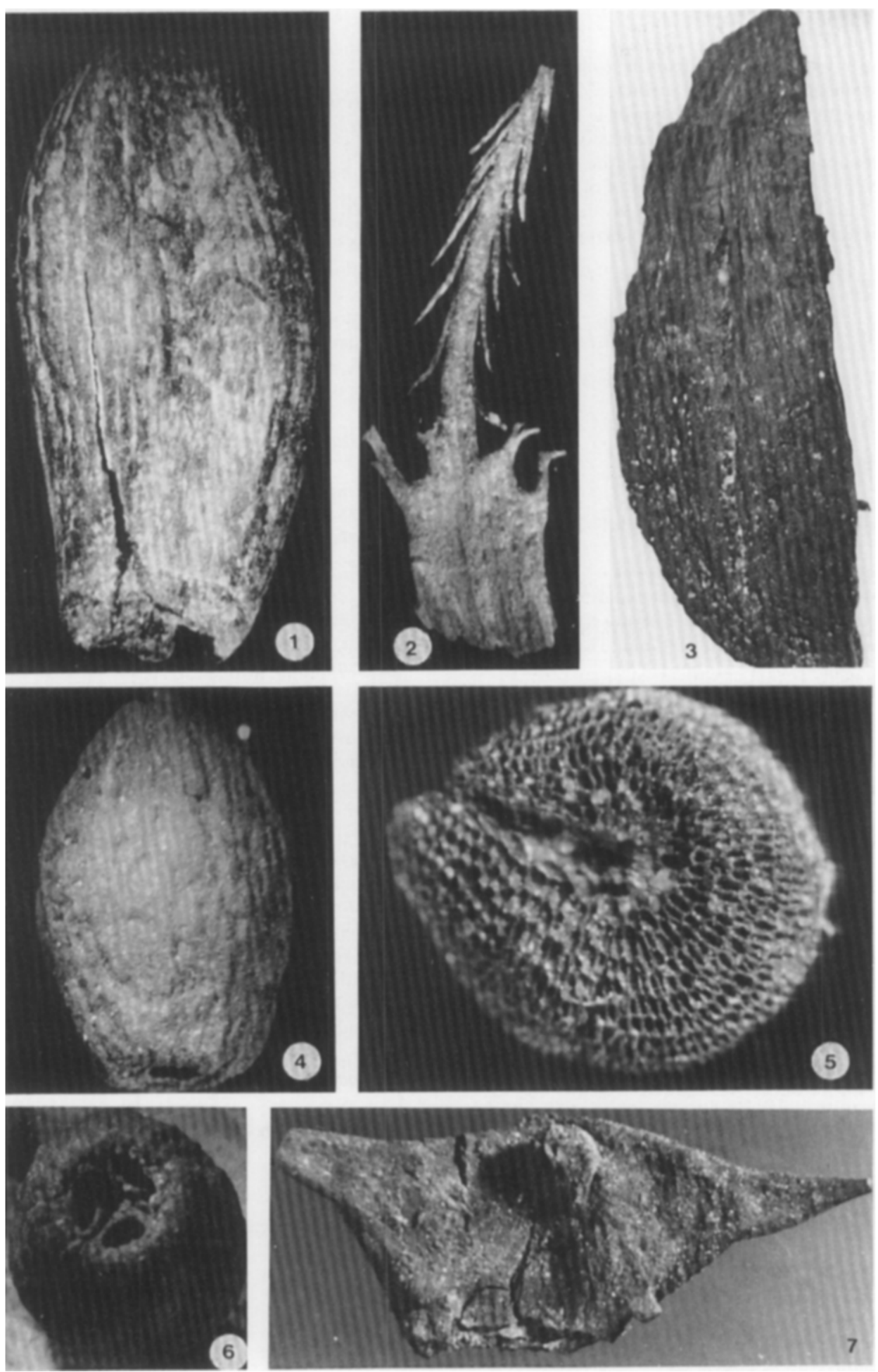


\section{UMBELLIFERAE}

Sium latifolium L. (Plate X, 1, 2)

Material studied: Fruits; coll. no.8334-6: 1 .

Remarks: This $2.4 \times 1.5 \mathrm{~mm}$ half fruit is compressed and split, which damaged the inner surface. Moreover the upper part, close to the base of the flower is missing. The outer surface bears five ribs with four slightly darker coloured depressions in between. Despite the preservation it is possible to identify this fruit as that of S. latifolium $\mathrm{L}$. Ecology: This fruit has been found in a clay deposit, which is consistent with the ecology of the modern plant, unit 2.

\section{Umbelliferopsis molassicus Gregor}

Material studied: Fruits; coll. no.14183-38: 1; 14399-19: 3; 14400-15: 1; 14402-26: 1 .

Ecology: See Van der Burgh (in press) (unit 3).

\section{VIOLACEAE}

Viola canina L. (Plate X, 3, 4)

Material studied: Seeds; coll. no.8335-29: 1; 8336-36: 1; 870035: 1; 14141-5: 3; 14183-20: 7; 14401-29: 3.

Remarks: These are small, $1.6-1.8 \times 0.9-1.3 \mathrm{~mm}$ ovate anatropous seeds. They are compressed and folded irregularly. The inner surface of the testa shows the characteristic transverse cellular pattern of Viola. The irregularly folded testa is typical for V. canina $\mathrm{L}$.

Ecology: $V$. canina is a species of forest margins and scrub vegetation on slightly acidic soil, not very rich in nutrients, unit 4 . The fossils have only been found in allochthonous floras, which is in accordance with the recent habitat.

\section{Viola rupestris Schmidt (Plate X, 5, 8)}

Material studied: Seeds; coll. no.14183-19: 5 .

Remarks: These are small, $2.0-2.2 \times 1.3-1.7 \mathrm{~mm}$ ovate anatropous seeds with the largest diameter close to the chalaza. The inner surface of the testa shows a transverse cellular pattern, characteristic for Viola. Parts of the outer surface are glossy, while other parts are lighter coloured and dull. These seeds are similar to those of $V$. rupestris Schmidt.

Ecology: V. rupestris is a species of pine forest in sandy soil, unit 7. The only find of the species in an allochthonous flora agrees with this.

\section{VITACEAE}

Ampelopsis malvaeformis (Von Schlotheim) Mai

A. ludwigii in: Van der Burgh (1983).

Material studied: Seeds; coll. no.8295-67: 1.

Remarks: As Mai and Gregor (1982) pointed out, the correct name for this species is not A.ludwigii but A. malvaeformis.

Ecology: In the lower Rhenish basin this species has been found in an allochthonous flora only. However, Mai (1964) and Mai and Gregor (1982) reported it from an autochthonous flora, while Gregor (1980) described it from a clay in which allochthonous elements were found in addition to an autochthonous flora. The recent species of the genus demonstrate a very wide ecological amplitude. Based on this A. malvaeformis is considered a species of floodplain forest, unit 5 .

\section{Tetrastigma lobata Chandler}

Material studied: Seeds; coll. no.7808-6: $1 ; 8295-4$ : 65; 8300-5: 1; 13285-14: 2 ; 13286-15: 1 ; 14139-3: 12 ; 14140-19: 46; 14143-14: 3; 14145-7: 18; 14146-16: 29.

Ecology: See Van der Burgh (in press) (units 3 and 5).

Vitis lusatica Czeczott et Skirgiello (Plate X, 6, 7)

Material studied: Seeds; coll. no.8295-80: 11; 8297-20: 2; 8699-41: 8; 8700-21: 2 ; 14141-22: 2 ; 14142-30: 6; 14183-12: 3 .

Remarks: Seeds of Vitaceae, $4.2-5.5 \times 2.7-3.9 \mathrm{~mm}$, with the area around the chalaza grooved radially. The apex has a deep groove at the raphe sinus. The seeds narrow abruptly to the base which bears conspicuous warts. These seeds are similar to $V$.lusatica as described by Czeczott and Skirgiello (1959).

Ecology: Vitis is a genus of vines which prefers to grow in wet to dry forest and forest margins. V. lusatica has only been found in allochthonous floras, which suggests a preference for drier localities alongside the river. Gregor (1980) reported it from an autochthonous flora with some allochthonous influence; Mai (1964) reported it from a lignite. So there is also the possibility of an occurrence in wetland forest; units 3 and 5 .

Vitis parasylvestris Kirchheimer (Plate XI, 1, 2)

Vitis sp. in: Van der Burgh (in press).

\section{PLATE X}

1,2. Sium latifolium; no.8334-6; $25 \times$.

3,4. Viola canina; 3 : no.14401-29; $24 \times$; 4 : no.14183-20; inner surface; $60 \times$.

5,8. Viola rupestris; no.14183-19; 8 : inner surface; $25 \times$.

6,7. Vitis lusatica; no.8295-80; $12.5 \times$. 


\section{PLATE X}
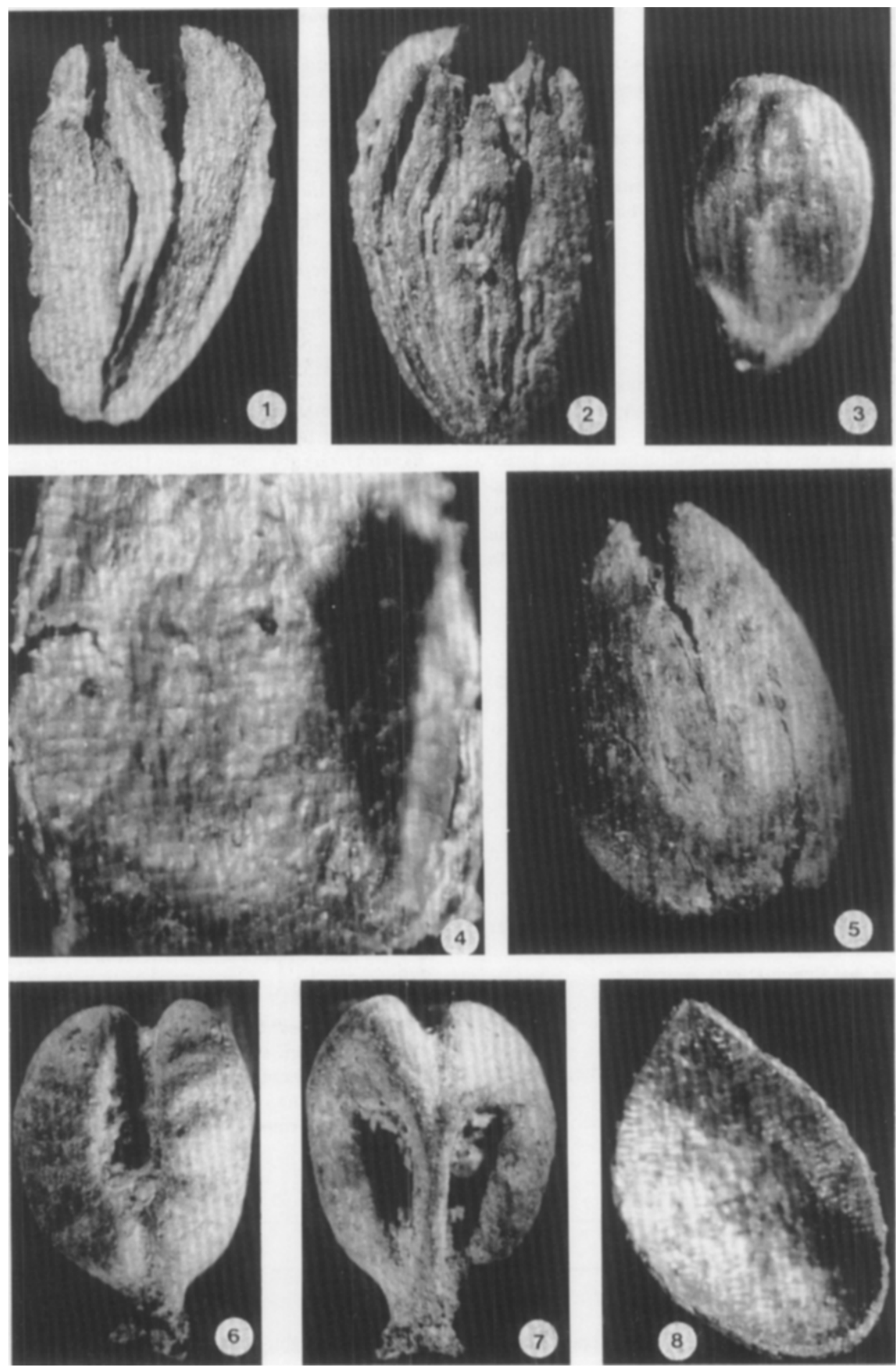
Material studied: Seeds; coll. no.7808-16: 2; 8295-17: 8 .

Remarks: These are seeds of Vitaceae, 5.0- $6.5 \times 3.4$ $4.0 \mathrm{~mm}$, with a smooth area around the chalaza, a very shallow groove for the raphe sinus at the apex and a gradual narrowing at the base. The base bears conspicuous warts. This material is similar to $V$.parasylvestris Kirchheimer (Mai, 1964).

Ecology: V.parasylvestris has been found in two samples, one containing an allochthonous flora, the other an autochthonous flora. In both the percentages are very low. It is therefore impossible to decide between units 3 and 5 .

\section{Vitis sp.}

Material studied: Seeds; coll. no.8300-25: 1; 13286-23: 1; 14399-18: 1 ; 14402-13: 1 ; 14428-13: 1 .

Remarks: These are very small fragments of seeds, sufficiently complete to identify the genus, but too incomplete for any further identification.

Ecology: Vitis sp. has been found in allochthonous floras. It is therefore expected to have been growing alongside rivers. As the percentages are very low, like the other identified species, it is very probable that the habitat of this unidentified material was similar too, units 3 and 5 .

Vitis teutonica A. Braun

Material studied: Seeds; coll. no.7808-15: 1; 8295-81: 29; 8699-25: 4; 14142-2: 6.

Ecology: Van der Burgh (in press) (units 3 and 5).

\section{MONOCOTYLEDONAE}

\section{ALISMATACEAE}

\section{Alisma plantago-aquatica $\mathrm{L}$}

Material studied: Fruits; coll. no.8334-4: 1; 14183-34: 1 ; 14428-18: 1 .

Ecology: See Van der Burgh (1983) (unit 2).

Caldesia cylindrica (Reid) Dorofeev

Material studied: Fruits; coll. no.8295-49: 3; 13349-3: 13; 14141-52: 1; 14183-17: 1 .

Ecology: See Van der Burgh (in press) (unit 2).

\section{ARACEAE}

Aracispermum canaliculatum Nikitin

Material studied: Seeds; coll. no.14429-16: 17.

Remarks: Although the similarity to Calla palustris is less close as suggested in a previous paper, the presence of a long raphe marks it as belonging to the same group within the family.

Ecology: The ecology of the species can be interpreted from its occurrence in a flora containing herbaceous vegetation and wetland forest. As the species does not occur in any other autochthonous flora and a fair amount of seeds has been extracted, it is still supposed to be a member of herbaceous vegetation, unit 2 .

Epipremnites ornatus (Reid et Chandler) Gregor et Bogner

Material studied: Seeds; coll. no.8700-26: 1; 13285-19: 3 ; 14401-14: 1 ; 14429-10; 6 .

Remarks: Gregor and Bogner (1984) propose a distribution of fossil Epipremnum over three genera: Urospathites (Epipremnum cristatum); Epipremnites (Epipremnum ornatum); and Scindapsites (Epipremnum crassum).

Ecology: See Van der Burgh (in press) (unit 2).

Scindapsites crassus (Reid et Reid) Gregor et Bogner

Epipremnum crassum in: Van der Burgh (1978).

Material studied: Seeds; coll. no.8295-38: 5; 8300-18: 1 ; 14140-26: 1 .

Ecology: According to Gregor and Bogner (1984) Scindap. sites crassus is related to Scindapsus, which is a liana in tropical forests. The finds of seeds however in the Upper Tertiary and lower Pleistocene point to an extratropical, even temperate forest, and the association with a fair number of herbaceous plants to an environment of wet herbaceous vegetations, unit 2 .

Urospathites cristatus (Nikitin) Gregor et Bogner (Plate XI, $7,8)$

Material studied: Seeds; coll. no.14141-11: 37.

Remarks: These are $2.5-4.0 \times 1.9-2.5 \mathrm{~mm}$ campylotropous seeds with rows of warty protuberances on the lateral and dorsal sides. The surface is brown and has a dull lustre, the epidermis is formed of parallel rows of elongated rectangu-

\section{PLATE XI}

1,2. Vitis parasylvestris; no.8295-17; $12.5 \times$.

3. Carex acuta; no.14183-35; $25 \times$.

4,5. Rhynchospora tertiaria; 4: Holotype, no.14401-32a; 5: Paratype, no.14401-32b; $25 \times$.

6,9. Scirpus melanospermus; no.8334-8; $6: 25 \times ; 9: 60 \times$.

7,8. Urospathites cristatus; no.14141-11; $12.5 \times$.

10. Eriophorum sp.; no.14401-35; $25 \times$. 


\section{PLATE XI}
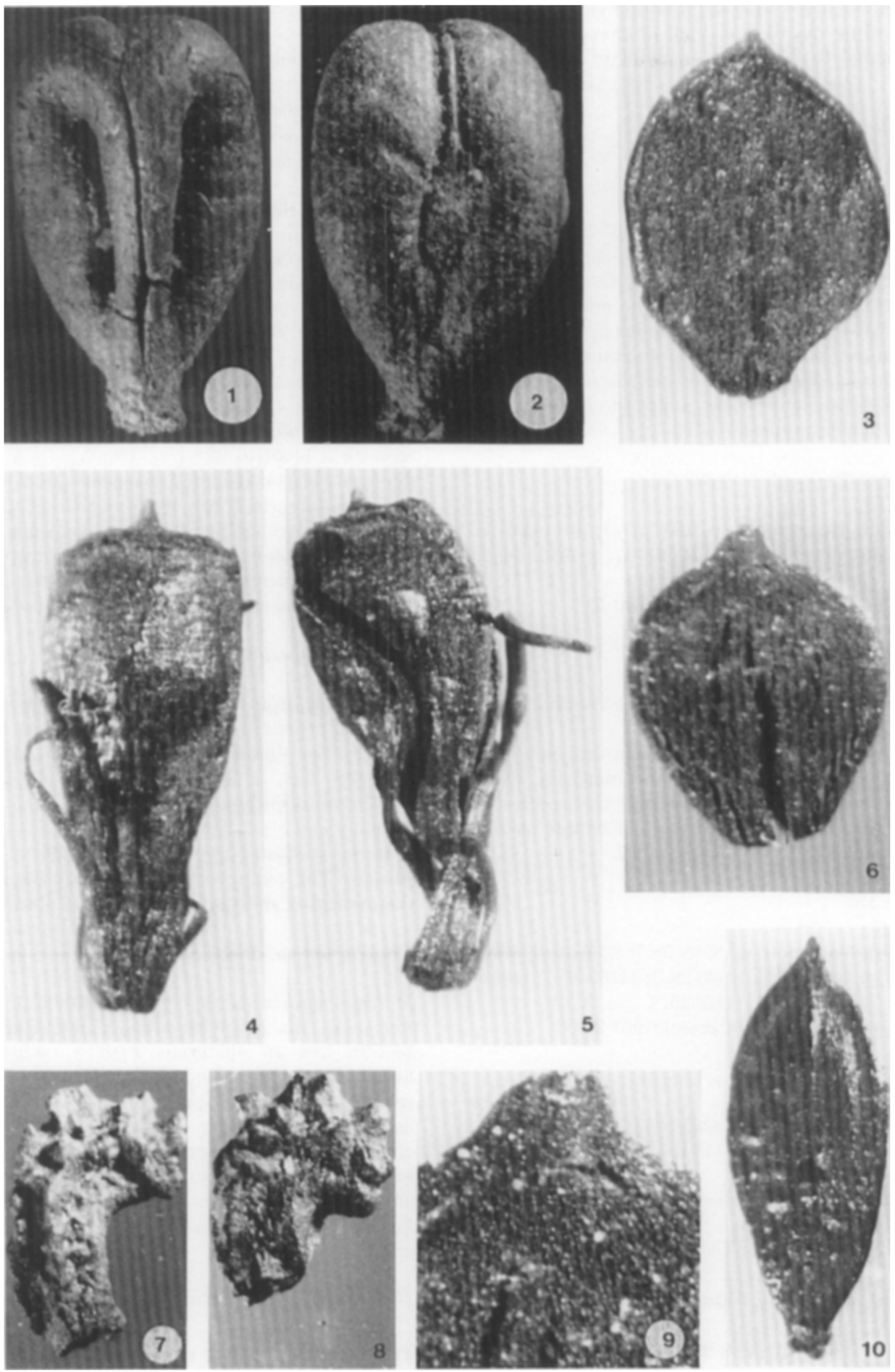
lar cells. These seeds are similar to Epipremnum cristatum, as described by Dorofeev (1963). Gregor and Bogner (1984) assigned it to their new genus Urospathites.

Ecology: According to Gregor and Bogner (1984) this material is related to Urospatha, a plant of wet places, unit 2.

\section{CYPERACEAE}

Carex acuta L. (Plate XI, 3)

Material studied: Nuts; coll. no.8334-9: 1; 8335-22: 7; 8336-34: 1; 8700-32: 25; 14141-42: 6; 14143-28: 1; 14183-35: 1 .

Remarks: Flat, $1.4 \quad 1.6 \times 0.8-1.2 \mathrm{~mm}$ nuts with a superficial cellular pattern in longitudinal rows. The apex is acuminate, as is the base, but with a hilum wider than the stylebase. These nuts are similar to those of extant C. acuta $\mathrm{L}$. Ecology: Extant C. acuta is a plant of wet places and banks. Our finds in allochthonous floras is not in contradiction with this environment, unit 2.

Carex acutiformis Ehrhard

Material studied: Nuts; coll. no.8295-71: 11; 14140-29: 9; 14141-35: 6; 14145-17: 1; 14183-15: 1; 14400-17: 2; 14401-36: 3; 14429-24: 5 .

Ecology: See Van der Burgh (in press) (unit 2).

Carex flagellata Reid et Reid

Material studied: Nuts; coll. no.8295-75: 2 ; 8334-10: 2 ; 833517: $1 ; 8336-22 ; 4 ; 8700-25: 30 ; 14141-36: 3$.

Ecology: The highest percentages of this extinct species are observed in floras originating from clay deposits. Even these percentages are low and therefore the species is considered to have lived in the same conditions as the other species: banks and wet places, unit 2 .

Carex hostiana DC.

Material studied: Nuts; coll. no.8295-70: 7; 8336-21: 6; 870031 : 21 ; 14140-30: 4 ; 14141-38: 5 ; 14143-29: 1 ; 14183-36: 1 ; 14399 20: 8 ; 14400-18: 1 ; 14401-37: 2; 14429-25: 1 .

Ecology: See Van der Burgh (in press) (unit 2).

Carex sp.

Material studied: Nuts; coll. no.8295-74: 3; 8335-30: $1 ; 8700$ 30: 5 ; 13285-17: 3 ; 14143-24: 2 ; 14146-1: 1 ; 14183-33: 4; 1440133: 1 ; 14429-26: 11.

Remarks: This material is too damaged to be identified at the specific level.

Ecology: As Carex is not confined to banks, but can also occur in forest, heath and peat bog; nothing can be said concerning this unidentified material.

Caricoidea jugata (Nikitin et Dorofeev) Mai

Material studied: Fruits; coll. no.7807-23: 13; 8295-87: 16; 8297-24: 1; 8335-21: 4; 8336-25: 5; 8700-36: 11; 13285-21: 1;
14140-28: $24 ; 14143-23: 10 ; 14145-18: 4 ; 14146-2: 9 ; 14399-14$ : $11 ; 14400-13: 4 ; 14401-41$ : 91 ; 14402-11: 4; 14429-15: 37.

Ecology: See Van der Burgh (in press) (unit 2).

Cladiocarya europaea Mai

Material studied: Endocarps; coll. no.7807-11: 1; 7808-18: 4; 8336-15: 4; 13286-28: 1 ; 14141-22: 2; 14399-15: 2; 14429-23: 6. Ecology: See Van der Burgh (in press) (unit 2).

Cladiocarya trebovensis (Buzek) Mai

Material studied: Endocarps; coll. no.7809-6: 13; 8295-88: 3; 8300-9: 3 ; 8335-9: 3 ; 13285-33: 2; 14399-21: 1 ; 14401-17: 141; 14429-27: 25.

Ecology: See Van der Burgh (in press) (unit 2).

Cladium reidiorum Nikitin

Material studied: Endocarps; coll. no.8295-86: 2; 8300-14: 2; 8335-19: 1; 14401-16: 42.

Ecology: Gregor recorded the genus from autochthonous floras in Bavaria (1980, 1982) and Greece (1983). On this basis it is considered a plant of reedswamps and peaty soil. Our allochthonous fruits are not in contradiction to this view, for the percentages are very low, like those of other plants from these habitats in allochthonous floras, unit 2 .

Dulichium spathaceum Reid et Reid

Material studied: Nuts; coll. no.8295-78: $1 ; 8336-18: 5 ; 8700-$ 17: 29 ; 14141-8: 4 ; 14428-17: 1 ; 14429-12: 10

Ecology: See Van der Burgh (1983) (unit 2).

Dulichium vespiforme Reid et Reid

Material studied: Nuts; coll. no.8336-29: 1.

Ecology: The ecology of this species is the same as that of the preceding species, banks and wet places, unit 2 .

Eriophorum sp. (Plate XI, 10)

Material studied: Nuts; coll. no.14401-35: 1 .

Remarks: This $2.4 \times 0.9 \mathrm{~mm}$ black nut, triangular in cross section has an epidermis with a cellular pattern of longitudinal rows of cells. The sides of the nut are not smooth as in other Cyperaceae, but show weak longitudinal ridges, suggesting a less massive wall beneath the epidermis. Within recent Cyperaceae such a character is sometimes observed within the genus Eriophorum. The material has been described as Eriophorum sp.

Ecology: Eriophorum is a genus of peat colonizing plants, unit 9.

Rhynchospora tertiaria nov. sp. (Plate XI, 4, 5)

Holotype: Coll. no.14401-32a (Plate XI, 4). Paratypus: Coll. no.14401-32b (Plate XI, 5). Locus typicus: Quarry "Zukunft West". 
Stratum typicum: Indener schichten.

Derivatio nominis: The first species to be described from Tertiary deposits.

Description: Flat, $2.1 \times 0.7-0.9 \mathrm{~mm}$ nuts with bristles at the base and a broad apex with a cicatrix of a broad attached flat style. In the middle of the apex a short spine is present. The surface shows longitudinally elongated cells but also transversely orientated rugulae. The bristles are at least as long as the nutlet.

Material studied: Nuts; coll. no.14401-32: 34 .

Remarks: Flat nutlets with broadly attached styles are only known to the author from Rhynchospora. R.fusca also shows the transversely orientated rugulae caused by transverse rows of cells in the epidermis. This species however has a much shorter nut and our material cannot be matched with it. Hence it is described as a new species.

Ecology: Rhynchospora is a plant of oligotrophic peat vegetations. It has only been found in an allochthonous flora from a sand deposit directly over a lignite seam. Previously the same species had been collected in a sand deposit within a Pliocene lignite in the open cast mine Frechen (sample 7805-18: 16 nuts). It was not recorded in Van der Burgh (1983), as it was not recognised at that time. Both localities strongly suggest an influence of lignite vegetation, which is in accordance with the recent habitat of the genus, unit 9 .

Scirpus lacustris L.

Material studied: Nuts; coll. no.8295-73: 2; 14401-38: 4. Ecology: This plant has only been found in allochthonous floras. At the present day it is a plant of swamp vegetations along banks of open water, unit 2 .

Scirpus melanospermus C.A. Mey. (Plate XI, 6, 9)

Material studied: Nuts; coll. no.8295-72: 1; 8334-8: 84; 1328522: 1 ; 14401-28: 3; 14428-15: 1.

Remarks: These small, $1.6-2.5 \times 0.9-1.4 \mathrm{~mm}$ nuts, flat to lenticular in cross section sometimes display remains of bristles at the base. The surface consists of an epidermis with longitudinal rows of cells. The lower layers of the wall of the nut are formed by longitudinally arranged sclerenchymatous fibres. These nuts are similar to material described as $S$. melanospermus C.A. Mey. by Dorofeev (1963).

Ecology: S. melanospermus is present with very low per- centages in some allochthonous floras. In a backswamp clay (no.8334) however it is dominant $(70 \%$ of the material). It is therefore considered to have lived in the same environments as the preceding species, unit 2 .

Scirpus tabernaemontani C.C. Gmelin

Material studied: Nuts; coll. no.8334-11: 1; 14141-37: 1; 14401-34: 5; 14428-16: 1.

Ecology: See S. lacustris, unit 2.

\section{HYDROCHARITACEAE}

Stratiotes tuberculatus Reid

Material studied: Seeds; coll. no.8295-24: 12; 14401-5: 1 . Ecology: At the present day Stratiotes is a plant of open water, where it grows in leeward places with very little disturbance. The finds of Gregor $(1980,1982)$ in autochthonous floras are in accordance with this ecosystem, unit 1.

\section{POTAMOGETONACEAE}

Potamogeton extremitatus nov. sp. (Plate XII, $1,2)$

Holotype: Coll. no.14428-8a, Laboratory of Palaeobotany and Palynology of the State university of Utrecht, the Netherlands (Plate XII, 1).

Paratype: Coll. no.14428-8b, Laboratory of Palaeobotany and Palynology of the state university of Utrecht, the Netherlands (Plate XII, 2).

Locus typicus: Quarry "Hambach".

Stratum typicum: Indener Schichten.

Derivatio nominis: The long spinelike projections at the base of the endocarp.

Description: Endocarp with projections $3.4 \times 1.9 \mathrm{~mm}$; without projections $2.2 \times 1.8 \mathrm{~mm}$. A short shoulder is present between style and germination pore. The lateral sides are flat with small depressions. On the back there is a spine in the middle, at the base there are ca $1 \mathrm{~mm}$ long spinelike projections on either side of the endocarp and a short spine on the lid of the germination pore, which also bears some short dentlike spines.

Material studied: Endocarps; coll. no.14428-8: 14.

Remarks: This material is very complete and yet unknown from the literature. It has therefore been described as a new species. 
Ecology: This genus is typically a waterplant; the totally unabraded state of the fruits of this species points to its presence at the place of deposition of the sediment, unit 1.

\section{Potamogeton sp.}

Material studied: Endocarps; coll. no.8334-12: 2; 8336-28: 2; 8699-33: 1 ; 13286-22: 1 ; 13349-8: 4; 14141-25: 1 ; 14183-18: 1 ; 14401-15: 1 .

Remarks: This is abraded material which cannot be identified at the specific level.

Ecology: Members of this genus of typical water plants can be expected in all allochthonous floras, unit 1.

\section{Ruppia palaeomaritima Negru (Plate XII, 3, 4)}

Material studied: Fruits; coll. no.8336-30: 1; 14401-23: 14 Remarks: These are $1.2-1.6 \times 0.8-1.0 \mathrm{~mm}$ black fruits, preserved with exocarp. The germination valve extends to the base of the style, so no shoulder is present. The lateral sides are semiglobose, no depression is present. These fruits are similar to $R$. palaeomaritima as described by Negru (1968, 1972).

Ecology: Ruppia is a genus of coastal aquatic and marine plants. Thus it is a marker of marine influence, unit 1.

\section{SPARGANIACEAE}

Sparganium haentzschelii Kirchheimer (Plate XII, 5, 11)

Material studied: Endocarps; coll. no.8295-63: 10; 8297-25: 1; 8300-26: 1; 8699-32: 1; 8700-24: 33; 14139-16: 1; 14141-14: 24; 14142-15: 3 ; 14183-37: 1 .

Remarks: These $2.8-4.0 \times 1.9-2.2 \mathrm{~mm}$ endocarps with a germination pore at the base of the style bear a variable number of longitudinal ridges and shallow grooves. This material is similar to $S$. haentzschelii described by Kirchheimer (1941).

Ecology: Sparganium is a genus of plants of shallow water and banks, unit 2 .

Sparganium minimum (Hartmann) Fries

Material studied: Endocarps; coll. no.8295-26: 2.

Ecology: See the preceeding species, unit 2.
Sparganium sp.

Material studied: Endocarps; coll. no.14429-23: 6.

Remarks: Small endocarps with a germination pore at the base of the style. They cannot be identified at the specific level.

Ecology: See Sparganium haentzschelii, unit 2.

\section{TYPHACEAE}

Typha sp. (Plate XII, 6, 7)

Material studied: Fruits; coll. no.7809-3: 190; 14428-19: 3 .

Ecology: See Van der Burgh (in press) (unit 1).

\section{ZINGIBERACEAE}

Spirematospermum wetzleri (Heer) Chandler

Material studied: Seeds; coll. no.7807-13: 2; 8334-1: 20; 14141-9: 2; 14429-4: 12.

Ecology: See Van der Burgh (in press) (unit 2)

\section{INCERTAE SEDIS}

Palliopora symplocoides Kirchheimer (Plate XII, 8-10)

Material studied: Fruits; coll. no.8295-36: 17; 8699-24: 2; 13285-3: 1 ; 14140-1: 31; 14142-11: 5; 14146-18: 1 .

Remarks: These are globular to oviform 14-29 mm long endocarps with 4-5 pores at the base around the abscission mark of the stalk. At the apex there is a narrow circular groove. Several fruits still bore remains of the exocarp. In the walls of the endocarp there are numerous small pores, communicating with lacunes which are connected with each other and form a spongelike structure around the massive central part of the endocarp which contains the locules. This material is similar to Palliopora symplocoides as described and figured by Kirchheimer (1934b, 1949). Concerning the systematic position of this genus, the presence of an exocarp, the smooth surface of the endocarp and the place of the germination pores at the base of the fruit link it with Sphenotheca and Symplocos, more than with any other genus of fossil or recent plants.

Ecology: This species has been found in allochthonous floras only. It is probable that such large woody fruits originated from a woody plant. Based on this and on the absence from autochthonous floras, the ecological amplitude has been confined to units 4,5 and 6 .

\section{PLATE XII}

1,2. Potamogeton extremitatus; 1: Holotypes, no.14428-8a; 2: Paratype, no.14428-8b; $25 \times$.

3,4. Ruppia palaeomaritima; no.14401-23; $25 \times$.

5,11. Sparganium haentzschelii; 5: bilocular endocarp; no.8700-24; $12.5 \times$.

6,7. Typha sp.; both pictures in transmitting light; 7: cellular structure of the subepidermal layer; no.7809-3; 6: 50 $\times$; 7: $500 \times$.

8,9,10. Palliopora symplocoides; 8: exocarp partly preserved; no.14140-1; $1 \times$ 
PLATE XII
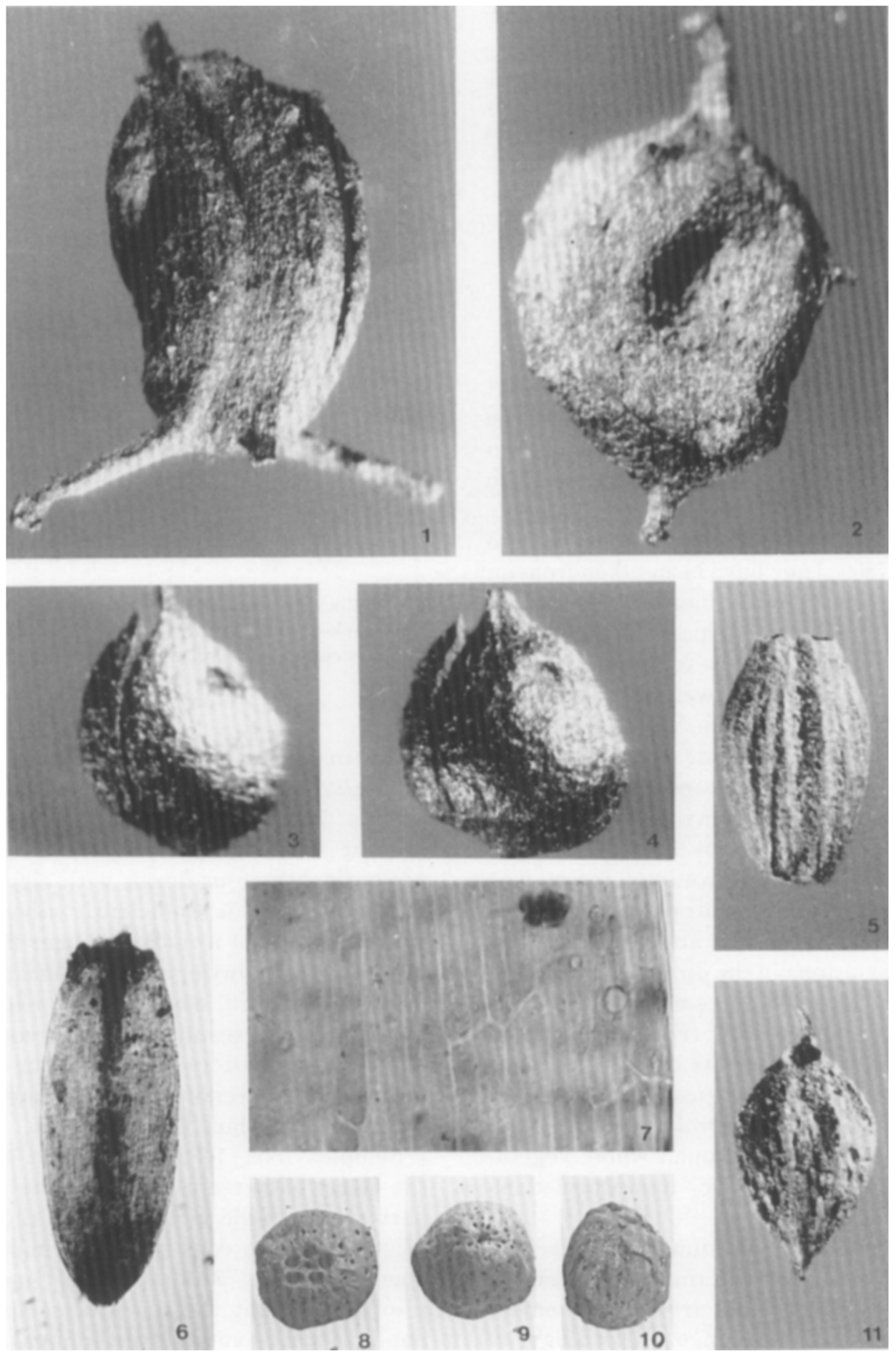
Sphenotheca incurva Kirchheimer

Material studied: Endocarps; coll. no.8295-32: 17; 13285-4: 1; 14139-2: 3 ; 14140-4: 5 ; 14142-12: 4; 14145-25: 3.

Ecology: This species has been found in allochthonous floras only, where it forms low percentages. It is therefore considered a plant of the drier parts of the river valley vegetation as well as other habitats. The woody fruit most probably originated from a woody plant. Thus its ecological conditions include units 4,5 and 6 .

\section{Discussion (Figs.1-6, for legenda see}

Fig.2)

\section{Zukunft West}

From the Ville Schichten in "Zukunft West" six samples were studied; together with three other samples (one from "Zukunft West", two from "Hambach") they were used to define the local vegetation (unit 2, 3 and 9).

Stratigraphically the oldest samples are no.7807 and 7809. They have been taken from an argillaceous lignite and a lignitic clay respectively. Therefore one can expect the vegetation to have been mesotrophic to eutrophic. Sample 7807 (Fig.1.a) represents a wetland forest with some influence from outside, which may have been transported to the site with the water which also carried the clay component of the sediment. The representation of unit 6 is a clear marker of this allochthonous influence.

The vegetation of this wetland forest was rather diverse, reflecting the comparative richness in nutrients of the soil and possibly other ecological variations in the direct environment of the sample site. This is emphasised by the contrast with sample 7809 (Fig.1.b) from the same horizon, which reflects only three types of vegetation: Scrub of Myrica with an admixture of Hypericum, Glyptostrobus and the vine Toddalia and swamp and open water vegetation, both dominated by monocotyledons (Typha, Caricoidea).

The first type of vegetation, Myrica scrub, might have been present in the flora of sample 7809 , for most of its species are also present in this sample. This difference in ecology is probably the reason for the difference in representation of the palaeotropical floral ele-
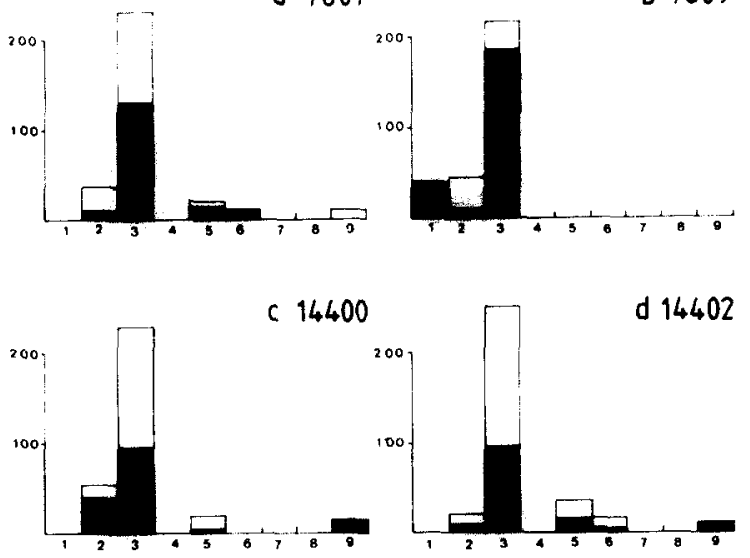

d 14402
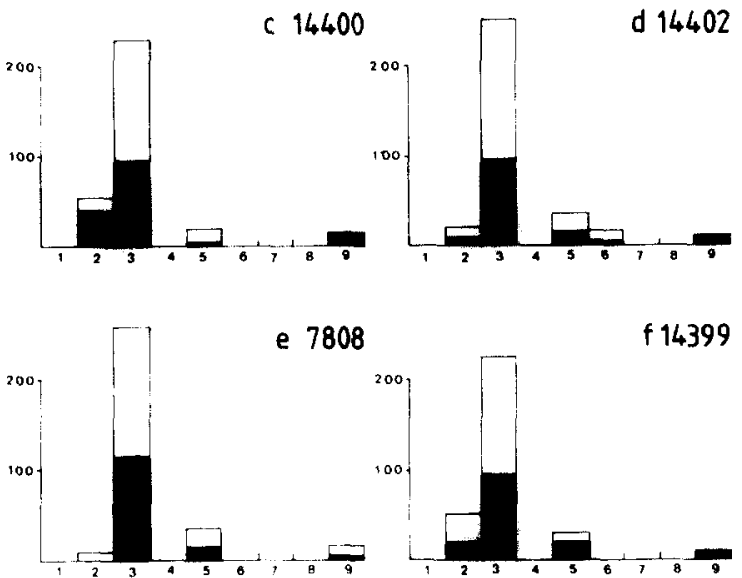

$f 14399$

Fig.1. Block diagrams of the vegetational composition of the samples $7807,7808,7809,14399,14400$ and 14402 . The numbers correspond with the vegetational units.

ment in the samples. In sample 7809 only Toddalia represents this floral element; in sample 7807 a true mastixioidean flora is present. Although species-poor in comparison with allochthonous floras, with eleven taxa in this sample it is sufficiently diverse to be characterised as a mastixioidean flora. However, the arctotertiary floral element is dominant in this flora, which can be explained for instance as a result of the mesotrophic to eutrophic conditions which favour deciduous plants. These deciduous plants mainly belong to the arctotertiary floral element.

Samples 7808, 14399, 14400 and 14402 from the Garzweiler seam represent the uppermost part of the Ville Schichten of the Miocene (Fig.1.c-d). The coal is locally impure in the open cast mine "Zukunft West" and this was also the case at the place of sampling. This implies that some allochthonous influences can be expected. As could be expected, unit 3 (wetland forest) is dominant; floodplain forest 
is not very well represented and of the typical upland vegetational units 6,7 and 8 , unit 6 is only represented in one sample (14402) and only as a minor component (14). Thus the allochthonous influence is not marked. Typical for all these floras is the total absence of open water vegetation and forest border-scrub, which points to a wide plain covered with vegetation growing in rather stable conditions. The rivers which may have carried the allochthonous elements must have been present at some distance from the site of deposition, nearly all the allochthonous material being filtered out before arriving at the place of sampling.

The small number of taxa recognised also points to a local vegetation (Van der Burgh, in press), but the flora is sufficiently rich to allow for an interpretation of a rather diverse vegetation ranging from oligotrophic to mesotrophic. The palaeotropical floral element is well represented: in all samples vegetational unit 3 is dominated by it. Unit 5 , representing drier circumstances, is rather poorly represented. In three of the four samples this unit is dominated by palaeotropical plants, in sample 14399 the arctotertiary floral element is dominating. Also in unit 2 the palaeotropical floral element is dominating in three of the four samples; in this case sample 14400 is the exception.

Overlying the Ville Schichten are a series of sediments known as the Indener Schichten in the western part and as Fischbach Schichten in the eastern part of the lower Rhenish basin. In "Zukunft West" the Indener Schichten consist of a basal part of marine sediment, a lignite seam ("upper seam") which locally shows marine erosion at the top and a series of fluviatile deposits, interfingering with marine sediments in the eastern part of the open cast mine. The edge of the marine erosion and sediments lies parallel to the Weisweiler fault at a short distance from it.

The lignite of the "upper seam" is very pure and therefore the flora can be expected to be local. One of the difficulties with this pure lignite is that it has been homogenised so

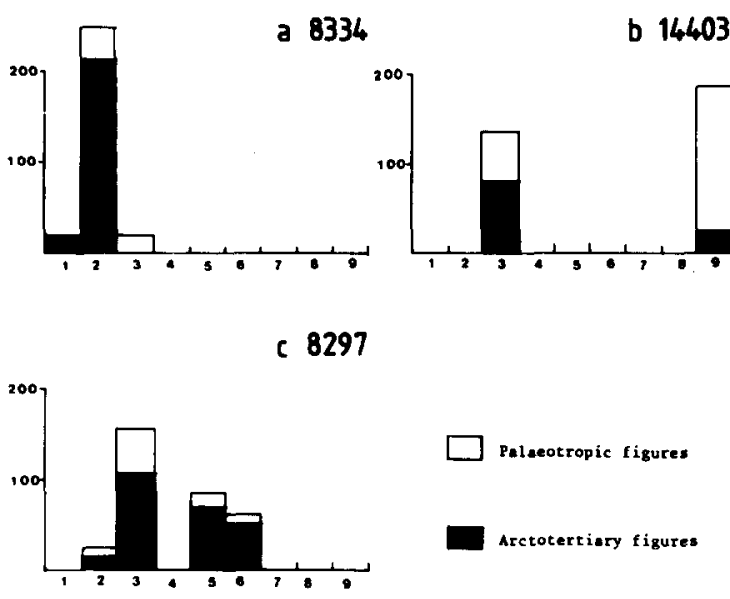

Fig.2. Block diagrams of the vegetational composition of the samples 8297,8334 and 14403 . The numbers correspond with the vegetational units.

thoroughly that, with the exception of some wood remains, no macrofossils could be obtained from it. In one sample however (no.14403, Fig.2.b), a flora could be extracted. It comprises ten taxa of which eight could be identified. Only vegetational unit 3 and 9 were present, the latter dominating. A peat bog represents an oligotrophic vegetation and its dominance is therefore a marker of a highly reduced or absent allochthonous element. The presence of unit 3 , wetland forest, can be ascribed to taxa able to survive in oligotrophic circumstances, the four taxa are all present in very reduced numbers. Thus, they may have been present in small dispersed stands of only a few taxa.

The arctotertiary taxa are dominant in unit 3 , and the palaeotropical taxa are dominant in the oligotrophic unit 9, as can be expected from a vegetational type which is favourable for evergreen taxa (Monk, 1966; Van der Burgh, 1973).

In the samples from allochthonous deposits a subdivision can be made according to the type of sediment. Sample 8334 (Fig.2.a) originates from a clay in overbank position and the flora is a reflection of it. It can be considered as autochthonous with a very minor allochthonous influence (only one seed of Magnolia). 
The herbaceous vegetation of swamps and river banks is dominant, and the vegetation of open water is only represented by two abraded endocarps of Potamogeton. The vegetation consisted of herbaceous plants, was dominated by Cyperaceae and Spirematospermum and can be considered as eutrophic. In this sample, though stratigraphically clearly correlated with samples having mastixioidean floras, no such flora is present. The palaeotropical element is restricted to the allochthonous Magnolia and the autochthonous Spirematospermum. This can be explained by the wealth of nutrients, which is in favour of arctotertiary taxa. Sample 8297, (Fig.2.c) from a sandy clay represents much more turbulent sedimentation. Consequently the number of taxa is higher and also the dispersion over the vegetational units is more even. Wetland forest dominates, but floodplain forest and upland forest are also rather well represented; the herbaceous vegetation is present but rare. Moreover, the arctotertiary floral element is dominant and again this could only be expected in a flora which represents local and sublocal vegetation growing in eutrophic conditions.

Floras from sands in river channels are clearly allochthonous. They represent the vegetation from a larger area upstream from their place of deposition. The river channel in "Zukunft West" had a south to north course and according to the general topography of the layers can be expected to have flowed in the same direction, with the sea to the north-east, parallel to the Weisweiler fault. As the base of the channel is nowhere in direct contact with the lignite of the "upper seam" within the pit, there is a fair possibility that all the peat bog taxa originate from still actively growing peatbogs in the vicinity. Numerous samples contained reworked material from peat bogs, which in most taxa was very easy to distinguish from freshly deposited material. However, not in all cases this was clear. These samples could therefore not be used for the present study which has been carried out on samples containing no recognisable reworked a 8300

b 8335

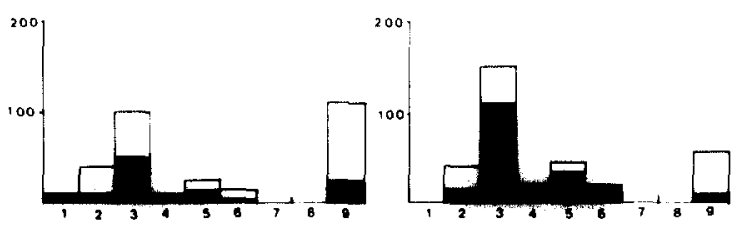

c 13285

d 13286
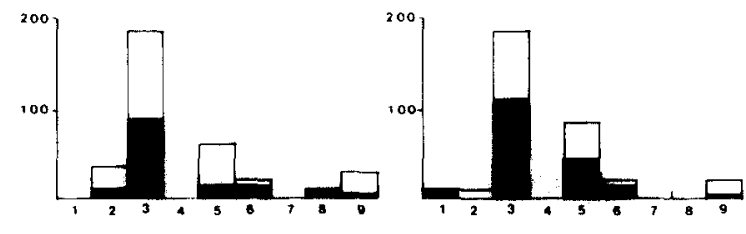

e 8336

f 14401
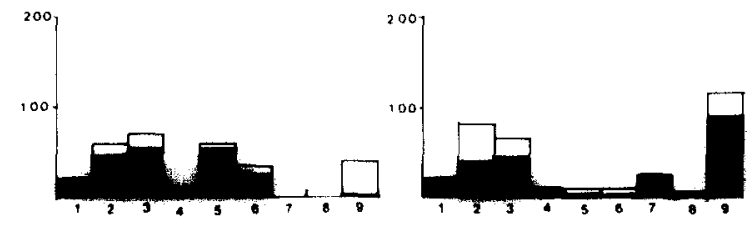

Fig.3. Block diagrams of the vegetational composition of the samples $8300,8335,8336,13285,13286$ and 14401 . The numbers correspond with the vegetational units.

material. From this river channel three samples were studied: 8300,8335 and 13285 (Fig.3.a-c). The peat bog was dominated by ericaceous taxa, notably Epacridicarpum. As this is considered to be a palaeotropical element, the flora of unit 9 is dominated by the palaeotropical floral element, which is entirely in accordance with what we found in the lignite of the "upper seam", where Epacridicar. pum was also present, though not dominant. In unit 3, Wetland forest, the palaeotropical floral element is more or less codominant with the arctotertiary flora, except in sample 8335, where the arctotertiary element only prevails. This points to more variation in the wetland forest than is found in the autochthonous floras and also to a wetland forest growing at least locally under less favourable conditions for arctotertiary taxa, possibly less eutrophic soil.

In all the three samples the upland forest is only poorly represented, the floodplain forest is 
represented by a moderate occurrence, as is the herbaceous vegetation. Open water is not or only poorly represented.

These samples are a reflection of a river flowing through in rather stable conditions in a wide plain, containing wetland forest, peat bog and to a limited extent floodplain forest. Upland vegetation is not present or only to a very limited degree. Open water conditions such as lakes and ponds are hardly represented in the flora and may therefore have been of very limited extent.

The presence of a coast line in the area is of interest for the vegetation. Part of the marineabraded lignite is covered by marine sands and shore deposits, part is covered by fluviatile sediments, so the coastline fluctuated with time. A clay deposit (sample 8336, Fig.3.e) and an accumulation of organic material in sand (sample 13286, Fig.3.d) were analysed. The organic material yields a flora which is fairly comparable to those obtained from the river channel: Dominance of wetland forest, good representation of floodplain forest, very poor representation of upland forest, open water and herbaceous vegetation. The representation of the peat bog is not marked, being dominated by the palaeotropical Epacridicarpum. Possibly this represents an accumulation of material, transported by the river(s) and not or only slightly influenced by their marine environment.

Sample 8336 shows a more even dispersion of the taxa over the units: from the upland vegetational units $3,6,7$ and 8 , only 6 is represented by moderate numbers. Similarly, peat bog environments are represented by a moderate occurrence, with the palaeotropical Epacridicarpum dominant. The herbaceous vegetation is represented by a rather high figure, indicating that in comparison with other samples rather more herbaceous vegetation was present. Regarding the distribution of the vegetation types little can be deduced from these two samples: Peat bogs mostly represent an inland vegetation and the same can be said for upland forest and forest border-scrub. However, the latter may have developed along the shore. Herbaceous vegetation, wetland forest and floodplain forest prefer more shelter. Therefore, either some shelter, for instance a sheltered bay, or a marked influence of upstream vegetation types can be assumed. The open water vegetation is also not very distinc. tive: Nymphaea is an inland genus, Potamogeton can be found in fresh and in brackish water, whereas Ruppia is a marine plant. Thus, the location and preservation of the samples point to marine sedimentation. However, the flora only weakly endorses this hypothesis by the somewhat higher amounts of herbaceous vegetation and the presence of a marine element.

Sample 14401 (Fig.3.f) was collected in a sand covering a lignite with clear marks of drainage by the nearby sea, but not showing any signs of transgression. The flora is typified by the presence of all nine vegetation units: The peat bog, herbaceous vegetation and wetland forest are represented by high figures, the coniferous forest by a moderate figure, all other units by small figures only. Particularly noteworthy are Corema, a typical coastal heather, Cupressoconus, which comes from a genus which is known to thrive also in coastal conditions, various species of Pinus, and Ruppia, a plant of marine open water.

The drainage of the peat bog by meandering canals was still visible and this may have caused its superficial desiccation and consequently a humification of the surface, enabling the development of herbaceous vegetation on the peat. The vegetation may have formed a mosaic with the herbaceous vegetation on the better drained parts and peat bog plants on the still very wet parts. In this situation Pinus and Cupressus, which are able to colonise poor soils, may have been present. In the peat bog vegetation ericaceous plants were still present, but as long as they are unidentified or belong to Erica, they are considered to be of arctotertiary affinity or their position is unknown. This implies that with the present knowledge dominance of palaeotropical floral elements in this vegetation cannot be found. The reason why these ericaceous plants are not found in other 
samples with strong representation of bog vegetation is as yet unknown. They may have been restricted to the somewhat drier habitats. On the peat there was a grassy vegetation with Eriophorum, Rhynchospora, Carex, Caricoidea, Cladiocarya, Cladium and Scirpus, with occasionally tussocks of the peat vegetation and Ericaceae. At times the sea rose and drowned the land, leaving some seeds of Ruppia and a thin layer of sand, which was subsequently bleached in the presence of acidic oligotrophic peat.

\section{Fortuna}

In the open cast mine "Fortuna" three samples (nos.8295, 8699, 8700, Fig.4.a-c) have been collected in the Fischbach Schichten. They were taken from a channel of a former river. Two samples were collected from a sand layer, the third from a silt layer over the sand, representing rather quiescent conditions dur-

a 8295

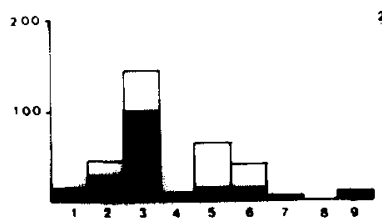

c 8700

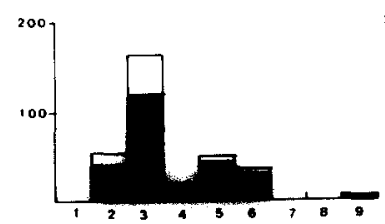

e 8334
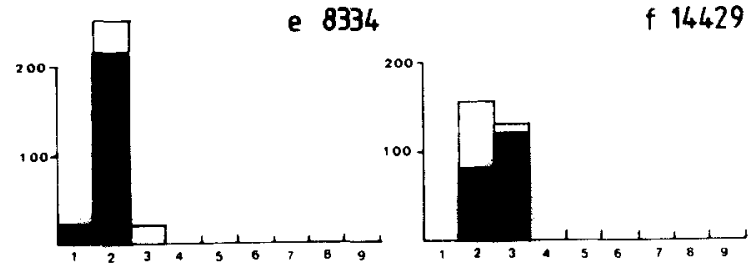

Fig.4. Block diagrams of the vegetational composition of the samples $8295,8334,8699,8700,13349$ and 14429 . The numbers correspond with the vegetational units. ing the last stage of sedimentation in the channel. In all three samples wetland forest is dominant, followed by herbaceous vegetation in the silt sample (no.8700) and by floodplain forest in the samples from the sand. Upland forest is represented by moderate figures and even by a high figure in sample 8699; open water vegetation, forest border-scrub, coniferous forest, heath and peat bog are not represented or only by low figures.

Typical is the overall dominance of the arctotertiary vegetation, with the exception of sample 8295 , in which the flora is very diverse (87 recognised taxa) and in which the palaeotropical floral element dominates the floodplain forest and upland forest. Compared with the river channel sediments of "Zukunft West" (Fig.3.a-c) bog vegetation is very poorly represented and therefore this river is considered to have flowed through a landscape with rather stable conditions, but with peat bog virtually lacking. The latter is in accordance with the absence of the "upper seam" in the vicinity.

\section{Hambach}

In the open cast mine "Hambach" most samples were collected in the uppermost division of the Indener Schichten, the top clay. Sample 14429 (Fig.4.f) was collected below this top clay in a clay-filled channel. Only units 2 and 3 are present: although clay is clearly of allochthonous origin, the dense plant cover, as suggested by the numerous compressions of monocotyledonous leaves, sieved all plant debris from outside the direct environment and so only the vegetation of the depression and its borders is represented. Both vegetational units are dominated by arctotertiary plants, a situation more or less similar to that in sample 8334 (Fig.4.e) from "Zukunft West", which was deposited in comparable circumstances. The same explanation as given for the latter sample may be used here. A lignitic clay representing the uppermost part of the top clay of the Indener Schichten offers a comparable situation (Sample 13349, Fig.4.d). It reflects a local vegetation consisting of a wetland forest, as 
shown by leaf compressions of Taxodium, Alnus, Viscum and Magnolia and various remains of stems and branches of trees. However, in this sample the flora contained some allochthonous elements (open water vegetation, floodplain forest, upland forest). The arctotertiary flora is likewise dominant in this sample.

The other samples originate from allochthonous sediments: No.14141 (Fig.6.b) is from a sand-filled channel below the top clay. Although wetland forest is dominant, the material is rather evenly dispersed over the other vegetational units with the exception of coniferous forest, heath and peat bog, which are not represented and herbaceous vegetation, which is rather markedly represented. Although some typical palaeotropical taxa are present, the flora as a whole is arctotertiary.

Samples nos.14139, 14140, 14142, 14143, 14145 and 14146 (Fig.5.a-f) are from shallow channels in the top clay. Unit 3 is dominant, followed by unit 5 and in most cases by unit 6 .

a 14139

b 14140
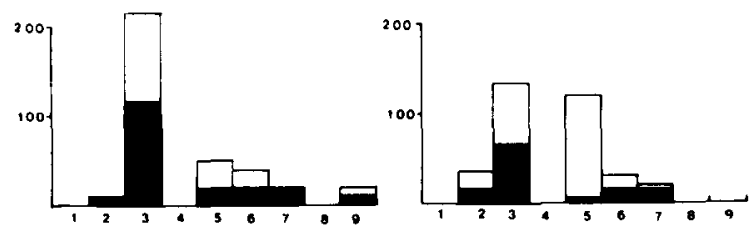

c 14142

d 14143
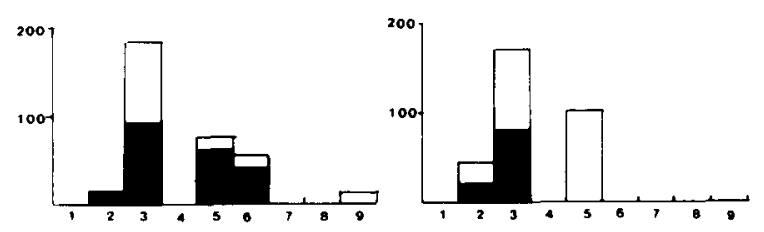

e 14145

f 14146
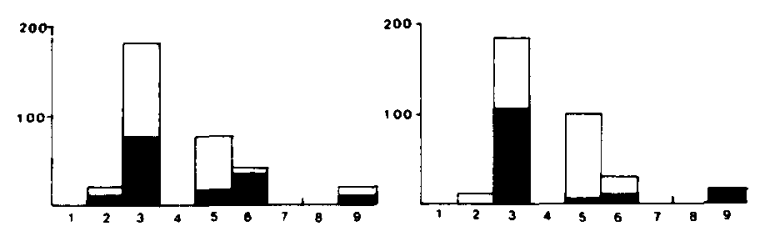

Fig.5. Block diagrams of the vegetational composition of the samples $14139,14140,14142,14143,14145$ and 14146 . The numbers correspond with the vegetational units.
However, in two samples unit 2 is also of some importance. Units 7 and 9 are sometimes present, while units 1,4 and 8 are lacking. Translated into the composition of a landscape: The river channels traversed a wide plain or valley of a major river. The plain, on a clay soil, was partly waterlogged and supported wetland forest and floodplain forest. In some dry places of limited extent or more probably outside the river valley upland forest types were present, notably upland forest (unit 6) and coniferous forest (unit 7). Locally there was some peat formation (still visible as a lignite seam within the clay). The vegetation was partly dominated by palaeotropical plants, especially in unit 5 (5 times out of 6), 3 (3 times), 9 and 6 (both once). In all cases a concentration of palaeotropical taxa in unit 3 and often a still greater concentration in unit 5 is significant. This points to a comparatively less favourable environment in these localities for arctotertiary plants. Combined with the effect of nutrient deficiency on the relation between arctotertiary and palaeotropical plants, this means that once more the dominance of arctotertiary plants is a result of sufficient nutrients in the low-lying wetland forest, and the dominance of the palaeotropical floral element in floodplain forest (unit 5) is a result of more oligotrophic circumstances in somewhat drier places. The macroclimate as a whole favoured the presence of palaeotropical taxa, whereas the microclimate and edaphic factors were the principal criteria for their numbers. Therefore we can consider these vegetations in "Hambach" as rather poor in nutrients, and thus mesotrophic. If we compare this with samples from the other mines, it appears that also in these pits the palaeotropical taxa are concentrated in units 3 and 5 , apart from a concentration in peat bog.

Since the scarcity in nutrients favour palaeotropical plants, one might expect this to apply to the upland vegetations as well. However, we find them dominated by arctotertiary taxa. If we compare these Upper Miocene floras with the Fagus-dominated leaf compression floras of the same deposits, it becomes clear that outside 
the river valleys and coastal plains, the arctotertiary floral element was dominant in the vegetation, giving these vegetations a "Pliocene" aspect - the leaf compression floras are comparable to the Pliocene leaf compression floras. Because clearly outside the river valleys and coastal plains nutrient deficiency must have existed on the deeply weathered alluvial soils, mainly sands, it is evident that some major factor inhibited the dominance of palaeotropical plants. We consider this major factor to be a climatic one, in other words: outside the direct influence of the sea basin and the shelter of valleys, the climate in the Upper Miocene was already unfavourable for palaeotropical taxa. We may drive this argument a little farther: As climate is a matter of greater entities, we may assume that the main climate in the Upper Miocene was already unfavourable for palaeotropical plants in the greater part of Northwestern Europe. Only in sheltered positions and in coastal areas could these floras survive or become dominant. In all other places the seasons were already too extreme for these plants. One of these relict areas was within the lower Rhenish basin and this was the reason for the survival in this area of many of the palaeotropical taxa, part of which can again be found in Brunssumian deposits.

Sample 14428 (Fig.6.c) was collected from a silt in the same channel as no.14140 (Fig.6.a). The differences are striking: much more local influence, dominance of river bank herbaceous vegetation, followed by that of open water. Also fewer palaeotropical plants, which are again concentrated in units 3 and 9 . The local flora is even more dominant as in the comparable sample from "Fortuna" (no.8700, Fig.6.e). Sample 14138 (Fig.6.d) was collected in a cyclic alternation of clay and sand overlying the top clay of the Indener Schichten. Whether it belongs to the Hauptkiesserie or to the Indener Schichten is still unclear. The flora is a reflection of rather unstable conditions with a dominance of floodplain forest, followed by wetland forest and herbaceous vegetation. Only bog and heathland vegetation are absent. a 14140

b 14141
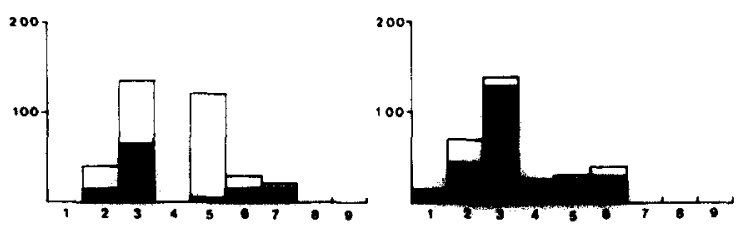

c 14428

d 14183
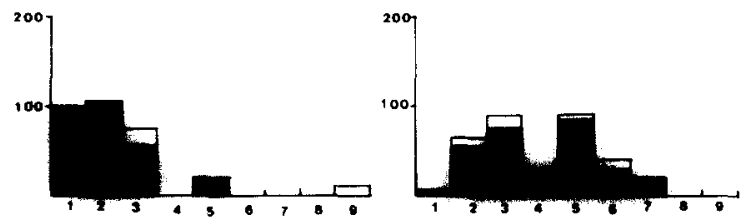

e 8700

f 8336
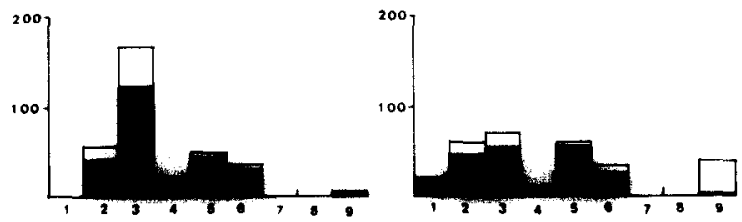

Fig.6. Block diagrams of the vegetational composition of the samples $8336,8700,14140,14141,14183$ and 14428 . The numbers correspond with the vegetational units.

On the one hand it is more or less comparable with sample 14141 (Fig.6.b) located in a series of sands, where rivers did not follow stable courses, but eroded and deposited very rapidly. On the other hand, it is also comparable with the marine clay deposit from sample 8336 (Fig.6.f), which also reflects a situation outside stable river deposits. In this flora dominance of palaeotropical taxa is not present.

\section{Conclusions}

During the late Miocene the lower Rhenish basin was a flat deltaic landscape, traversed by sluggish shallow rivers with wide swampy bottomlands. Apart from open water and places affected by erosion or comparatively rapid deposition, the vegetation was dominated by forest.

In the open water Nymphaeaceae and submerged vegetations occurred, along the banks there were vegetation types consisting mainly 
of monocotyledons, merging into more diverse herbaceous vegetations on drier sites.

In the wet bottomlands wetland forest dominated. It very often formed peat and probably had a very wide distribution in these badly drained surroundings.

On less often flooded places (e.g. levees) floodplain forest occurred, but this type of vegetation was of limited extent.

The upland forest also was of limited distribution and occurred outside the river valleys on only occasionally flooded soil. If these dry soils were poor in nutrients, coniferous forest developed. This also was of limited extent.

Heath was not very well developed, only in coastal areas it might have been of some importance.

Oligotrophic peat bog vegetation was present in places where there was plenty of water and lack of nutrients. In the wet climate of the late Miocene (Mai, 1967; Van der Burgh, 1983), it may have been of considerable extent. The lack of nutrients also favoured the develop- ment of the Mastixioideae-flora in those situations where the climate was sufficiently warm for its development, which was only in the valleys and in the coastal area.

\section{Acknowledgements}

The author wishes to thank the board of the "Rheinbraun" for permission to collect in their quarries. Furthermore he is very grateful to Ir Nehring, Ir Kothen and their collaborators at the staff division B 41 of "Rheinbraun" for help and support in collecting. Also thanks are due to the staff at the quarries. The author thanks his colleague, Dr. J.R. Boersma, for help and advise in sedimentological questions and his colleagues from the laboratory of Palaeobotany and Palynology at Utrecht for discussion and stimulation. Thanks are also due to $\mathrm{Mr}$ H.A. Elsendoorn for his invaluable help in preparing the photographs and Prof Dr. D.K. Ferguson for critical reading of the manuscript.

\section{Appendix ${ }^{1}$}

\begin{tabular}{|c|c|c|c|c|c|c|c|c|c|c|c|c|c|c|c|c|c|c|}
\hline \multirow[t]{2}{*}{ Species } & & \multicolumn{17}{|c|}{ Vegetational units } \\
\hline & & 1 & & 2 & & 3 & & 4 & & 5 & & 6 & & 7 & & 8 & & 9 \\
\hline Alnus sp. & $3^{*}$ & & & & $3^{*}$ & & & & & & & & & & & & & \\
\hline Caricoidea jugata & $\underline{13}^{*}$ & & $\underline{13}^{\star}$ & & & & & & & & & & & & & & & \\
\hline Carya ventricosa & $4^{\star}$ & & & & $4^{\star}$ & & & & & & & & & & & & & \\
\hline Cladiocarya europaea & $1^{*}$ & & $\underline{1}$ & & & & & & & & & & & & & & & \\
\hline Cornus bugloviana & $3^{\star}$ & & & & $3^{*}$ & & & & & & & & & & & & & \\
\hline Eomastixia persicoides & $\underline{7}^{\star}$ & & & & $\underline{7}^{*}$ & & & & & & & & & & & & & \\
\hline Eurya stigmosa & $\overline{\mathbf{1}}^{*}$ & & & & $\underline{1}^{*}$ & & & & & & & & & & & & & \\
\hline Fagus decurrens & $\mathbf{1}^{*}$ & & & & & & & & & & $1^{*}$ & & & & & & & \\
\hline Glyptostrobus europaeus & $18^{\star}$ & & & & $18^{*}$ & & & & & & & & & & & & & \\
\hline Ilex thuringiaca & $1 *$ & & & & $\underline{1}^{*}$ & & & & & & & & & & & & & \\
\hline Liriodendron geminatum & $4^{*}$ & & & & 4 & & & & $4^{*}$ & & & & & & & & & \\
\hline Magnolia burseracea & $\underline{57^{*}}$ & & & & $\underline{\mathbf{5 7}}$ * & & & & & & & & & & & & & \\
\hline Magnolia lignita & $2^{*}$ & & & & 2 & & & & & & & & & & & & & \\
\hline Magnolia lusatica & $\overline{3}^{*}$ & & & & $\underline{3}^{*}$ & & & & & & & & & & & & & \\
\hline Magnolia sp. & $\underline{7}^{*}$ & & & & $\underline{72}^{*}$ & & & & & & & & & & & & & \\
\hline Mneme menzelii & $\overline{4}^{*}$ & & $4^{*}$ & & & & & & & & & & & & & & & \\
\hline Myrica ceriferiformis & $52^{*}$ & & & & $52^{*}$ & & & & & & & & & & & & & \\
\hline Myrica minima & $171^{\star}$ & & & & $171^{*}$ & & & & & & & & & & & & & \\
\hline Myrica suppanii & $\underline{7}^{\star}$ & & & & 7 & & & & & & & & & & & & $\underline{7}^{\star}$ & \\
\hline Pterocarya limburgensis & $\overline{2}^{*}$ & & & & $\overrightarrow{2}^{*}$ & & & & & & & & & & & & & \\
\hline Rubus laticostatus & 17 & & & & 17 & & 17 & & 17 & & 17 & & 17 & & 17 & & & \\
\hline Sambucus pulchella & 1 & & & & 1 & & 1 & & 1 & & & & & & & & & \\
\hline Sorbus herzogenrathensis & $2^{*}$ & & & & $2 *$ & & & & & & & & & & & & & \\
\hline Spirematospermum wetzleri & $\underline{2}$ & & $\underline{2}^{\star}$ & & & & & & & & & & & & & & & \\
\hline Symplocos lignitarum & $\underline{1}$ & & & & 1 & & & & $\underline{1}^{*}$ & & & & & & & & & \\
\hline Taxodium dubium & $3^{*}$ & & & & $3^{*}$ & & & & & & & & & & & & & \\
\hline Toddalia rhenana & $\underline{5}^{*}$ & & & & $\underline{\mathbf{5}}^{\star}$ & & & & & & & & & & & & & \\
\hline
\end{tabular}

\footnotetext{
${ }^{1}$ Taxa which are considered characteristic for a vegetational unit have been marked with an asterisk. Palaeotropical taxa have been marked with an underline. For further information see p.301: Ecology.
} 
Sample 7807 (continued)

\begin{tabular}{|c|c|c|c|c|c|c|c|c|c|c|c|c|c|c|c|c|c|c|c|}
\hline \multirow[t]{2}{*}{ Species } & & & \multicolumn{17}{|c|}{ Vegetational units } \\
\hline & & & 1 & & 2 & & 3 & & 4 & & 5 & & 6 & & $i$ & & 8 & & $y$ \\
\hline ? & 30 & & & & & & & & & & & & & & & & & & \\
\hline$?$ & 10 & & & & & & & & & & & & & & & & & & \\
\hline ". & 4 & & & & & & & & & & & & & & & & & & \\
\hline ? & 3 & & & & & & & & & & & & & & & & & & \\
\hline ! & 1 & & & & & & & & & & & & & & & & & & \\
\hline$\sum \operatorname{tax} a$ & 32 & & & 4 & $13 \%$ & 22 & $69^{\circ}$ & 2 & & 4 & $13^{41 ;}$ & 2 & $6^{2}$ & 1 & & 1 & & 1 & 30 \\
\hline$\Sigma$ characteristic taxa & 25 & & & 4 & $16 \%$ & 17 & $68 \%$ & & & 2 & $8 \%$ & 1 & $4^{313}$ & & & & & 1 & $4^{n ! i n}$ \\
\hline$\Sigma$ fruits and seeds & 507 & - & & 20 & & 436 & & 18 & & 23 & & 18 & & 17 & & 17 & & $i$ & \\
\hline$\Sigma$ char fruits and seeds & 441 & $\cdot$ & & 20 & $5 \%$ & 406 & $92 \%$ & & & 5 & $1^{+1 \%}$ & 1 & , & & & & & 7 & 2 \\
\hline Vegetation figures & & & & & 34 & & 229 & & & & 22 & & 10 & & & & & & 9 \\
\hline$\Sigma$ palaeotropic taxa & 13 & & & 3 & $9 \%$ & 10 & $31 \%$ & & & 1 & $3^{\circ}$ & & & & & & & 1 & $3^{2} \ldots$ \\
\hline$\Sigma$ pal. char. taxa & 13 & & & 3 & $12 \%$ & 8 & $32 \%$ & & & 1 & $4 \%$ & & & & & & & 1 & 4 \\
\hline$\Sigma$ pal. char. vrts and seeds & 172 & - & & 16 & $4_{\%}^{\prime \prime \prime}$ & 148 & $34 \%$ & & & 1 & x & & & & & & & 7 & $2^{2}$, \\
\hline Palaeotropic figures & & & & & 25 & & 97 & & & & 7 & & & & & & & & 9 \\
\hline Arctotertiary figures & & & & & 9 & & 132 & & & & 15 & & 10 & & & & & & \\
\hline
\end{tabular}

\section{Sample 7808}

\begin{tabular}{|c|c|c|c|c|c|c|c|c|c|c|c|c|c|c|c|c|c|c|c|}
\hline \multirow[t]{2}{*}{ Species } & & & \multicolumn{17}{|c|}{ Vegetational units } \\
\hline & & & 1 & & 2 & & 3 & & 4 & & 5 & & 6 & & 7 & & 8 & & 9 \\
\hline Chionanthus ruehlii & $6^{*}$ & & & & & $6^{\star}$ & & & & & & & & & & & & & \\
\hline Cladiocarya europaea & $\underline{4}^{\star}$ & & & $4^{\star}$ & & & & & & & & & & & & & & & \\
\hline Cornus bugloviana & $\overline{1}^{\star}$ & & & & & $1^{*}$ & & & & & & & & & & & & & \\
\hline Eurya stigmosa & $680^{\star}$ & & & & & $680^{\star}$ & & & & & & & & & & & & & \\
\hline Glyptostrobus europaeus & $\overline{5}$ & & & & & $\overline{5}$ & & & & & & & & & & & & & \\
\hline Homalanthus costatus & $11^{*}$ & & & & & $11^{*}$ & & & & & & & & & & & & & \\
\hline Ilex jonkeri & 1 & & & & & 1 & & & & & & 1 & & 1 & & & & & \\
\hline Ilex saxonica & $\overline{2}$ & & & & & $\stackrel{2}{2}$ & & & & & & $\underline{2}$ & & 2 & & & & & \\
\hline duniperus oxycedrus & $\overline{2} \star$ & & & & & $2^{*}$ & & & & & & & & & & & & & \\
\hline Magnolia burseracea & $\underline{8}^{*}$ & & & & & $8^{\star}$ & & & & & & & & & & & & & \\
\hline Myrica boveyana & $\underline{11}^{\star}$ & & & & & 11 & & & & & & & & & & & & $11^{*}$ & \\
\hline Myrica ceriferiformis & $\overline{16} 6^{\star}$ & & & & & $16^{*}$ & & & & & & & & & & & & & \\
\hline Myrica minima & $33^{*}$ & & & & & $33^{*}$ & & & & & & & & & & & & & \\
\hline Pinacege & 1 & & & & & 1 & & & & & & 1 & & 1 & & & & 1 & \\
\hline Rubus laticostatus & 25 & & & & & 25 & & 25 & & 25 & & 25 & & 25 & & 25 & & & \\
\hline Sequoiz langsdorfii & $17^{\star}$ & & & & & $17^{*}$ & & & & & & & & & & & & & \\
\hline Sorbus herzogenrathensis & $519^{*}$ & & & & & $519^{\star}$ & & & & & & & & & & & & & \\
\hline Symplocos germanica & $\underline{20^{*}}$ & & & & & $20^{*}$ & & & & & & & & & & & & & \\
\hline Symplocos gothanii & $\underline{79}^{\star}$ & & & & & $79^{*}$ & & & & & & & & & & & & & \\
\hline Symplocos lignitarum & $\overline{9}$ & & & & & $\overline{9}$ & & & & $\underline{9}^{\star}$ & & & & & & & & & \\
\hline Symplocos salzhausenensis & $9^{*}$ & & & & & $q^{*}$ & & & & & & & & & & & & & \\
\hline Symplocos schereri & 1 & & & & & & & & & 1 & & 1 & & & & & & & \\
\hline Tetrastigma lobata & $\overline{1}^{*}$ & & & & & 1 & & & & $1^{*}$ & & & & & & & & & \\
\hline Toddalia rhenana & $\underline{1}^{*}$ & & & & & $1^{\star}$ & & & & & & & & & & & & & \\
\hline Vitis parasylvestris & $\overline{2}$ & & & & & 2 & & & & 2 & & & & & & & & & \\
\hline Vitis teutonica & $\mathrm{I}^{*}$ & & & & & 1 & & & & $1^{*}$ & & & & & & & & & \\
\hline$?$ & 5 & & & & & & & & & & & & & & & & & & \\
\hline$?$ & 1 & & & & & & & & & & & & & & & & & & \\
\hline$\sum \operatorname{tax} \theta$ & 28 & $\ldots$ & & 1 & $4 \%$ & 24 & $86 \%$ & 1 & & 6 & $21 \%$ & 5 & & 4 & & 1 & & 2 & $\tau_{*}^{*}$ \\
\hline$\sum$ characteristic taxa & 20 & & & 1 & $5 \%$ & 15 & $75 \%$ & & & 3 & $15 \%$ & & & & & & & 1 & $5 \%$ \\
\hline$\Sigma$ fruits and seeds & 1471 & - & & 4 & & 1460 & & 25 & & 39 & & 30 & & 29 & & 25 & & 12 & \\
\hline I char. fruits and seeds & 1433 &.- & & 4 & $\times$ & 1407 & $98 \%$ & & & 11 & $1 \%$ & & & & & & & 11 & $1_{i}$ \\
\hline Vegetation figures & & & & & 9 & & 259 & & & & 37 & & & & & & - & & 13 \\
\hline I palaeotropic taxa & 15 & & & 1 & $4^{17 \%}$ & 13 & $46 \%$ & & & 3 & $11 \%$ & 3 & & 2 & & & & 1 & $4 \%$ \\
\hline$\Sigma$ pal. char taxa & 12 & .. & & 1 & $5 \%$ & 8 & $40 \%$ & $\ldots$ & & 2 & $10 \%$ & & & & & & & 1 & $5 \%$ \\
\hline I pal. char. frts and seeds & 835 & - & & 4 & $x$ & 813 & $57 \%$ & & & 10 & 10 & & & & & & & 11 & $1 \%$ \\
\hline Palaeotropic figures & & & & & 9 & & 143 & & & & 22 & & & & & & . & & 10 \\
\hline Arctotertiary figures & & & & & & & 116 & & $\ldots$ & & 15 & & & & & & & & 3 \\
\hline
\end{tabular}


Sample 7809

\begin{tabular}{|c|c|c|c|c|c|c|c|c|c|c|c|c|c|c|c|c|c|c|c|}
\hline \multirow[t]{2}{*}{ Species } & & & \multicolumn{17}{|c|}{ Vegetational units } \\
\hline & & & 1 & & 2 & & $\mathbf{3}$ & & 4 & & 5 & & 6 & & 7 & & 8 & & 9 \\
\hline Cladiocarya trebovensis & $\underline{13}^{*}$ & & & $\underline{13}^{*}$ & & & & & & & & & & & & & & & \\
\hline Glyptostrobus europaeus & $1^{*}$ & & & & & $1^{*}$ & & & & & & & & & & & & & \\
\hline Hypericum holyi & 87 & & & 87 & & 87 & & & & & & & & & & & & & \\
\hline Myrica ceriferiformis & $2171^{*}$ & & & & & $2171^{*}$ & & & & & & & & & & & & & \\
\hline Myrica minima & $98^{*}$ & & & & & $98^{*}$ & & & & & & & & & & & & & \\
\hline Toddalia rhenana & $\underline{5}^{\star}$ & & & & & $\underline{5}^{*}$ & & & & & & & & & & & & & \\
\hline Typha sp. & $190^{\star}$ & $190^{\star}$ & & & & & & & & & & & & & & & & & \\
\hline$?$ & 13 & & & & & & & & & & & & & & & & & & \\
\hline$\Sigma$ taxa & 8 & 1 & $13 \%$ & 2 & $25 \%$ & 5 & $62 \%$ & & & & & & & & & & & & \\
\hline$\Sigma$ characteristic taxa & 6 & 1 & $17 \%$ & 1 & $17 \%$ & 4 & $66 \%$ & & & & & & & & & & & & \\
\hline$\Sigma$ fruits and seeds & 2578 & 190 & & 100 & & 2362 & & & & & & & & & & & & & \\
\hline$\Sigma$ char. fruits and seeds & 2465 & 190 & $8 \%$ & 13 & $1 \%$ & 2275 & $91 \%$ & & & & & & & & & & & & \\
\hline Vegetation figures & & & 38 & & 43 & & 219 & - & & - & & - & & - & & - & & - & \\
\hline$\Sigma$ palaeotropic taxa & 2 & - & & 1 & $13 \%$ & 1 & $13 \%$ & & & & & & & & & & & & \\
\hline$\Sigma$ pal. char. taxa & 2 & - & & 1 & $17 \%$ & 1 & $17 \%$ & & & & & & & & & & & & \\
\hline$\Sigma$ pal. char. frts and seeds & 18 & - & & 13 & $1 \%$ & 5 & $x$ & & & & & & & & & & & & \\
\hline Palaeotropic figures & & & - & & 31 & & 30 & - & & - & & - & & - & & - & & - & \\
\hline Arctotertiary figures & & & 38 & & 12 & & 189 & - & & - & & - & & - & & - & & - & \\
\hline
\end{tabular}

Sample 8297

\begin{tabular}{|c|c|c|c|c|c|c|c|c|c|c|c|c|c|c|c|c|c|c|c|}
\hline \multirow[t]{2}{*}{ Species } & & & \multicolumn{17}{|c|}{ Vegetational units } \\
\hline & & & 1 & & 2 & & 3 & & 4 & & 5 & & 6 & & 7 & & 8 & & 9 \\
\hline Alnus sp. & $1^{*}$ & & & & & $1^{\star}$ & & & & & & & & & & & & & \\
\hline Caricoidea jugata & $1^{\star}$ & & & $1^{\star}$ & & & & & & & & & & & & & & & \\
\hline Crataegus nodulasa & $\overline{1}$ & & & & & & & 1 & & 1 & & 1 & & & & & & & \\
\hline Crataegus sp. & 1 & & & & & & & 1 & & 1 & & 1 & & & & & & & \\
\hline Decodon globosus & $2^{*}$ & & & $2 *$ & & & & & & & & & & & & & & & \\
\hline Eurya stigmosa & $5^{\star}$ & & & & & $\underline{5}^{*}$ & & & & & & & & & & & & & \\
\hline Fagus decurrens & $\overline{5}^{\star}$ & & & & & & & & & & & $5^{\star}$ & & & & & & & \\
\hline Glyptostrobus europaeus & $8^{*}$ & & & & & $8^{*}$ & & & & & & & & & & & & & \\
\hline Homalanthus costatus & $\underline{1}$ * & & & & & $\underline{1}^{*}$ & & & & & & & & & & & & & \\
\hline Leucothoe narbonnensis & $\frac{2}{2}$ & & & & & $\frac{2}{2}$ & & & & 2 & & & & & & & & 2 & \\
\hline Liriodendron geminatum & $23^{\star}$ & & & & & 23 & & & & $23^{*}$ & & & & & & & & & \\
\hline Meliosma wetteraviensis & $\underline{2}^{\star}$ & & & & & $\underline{2}^{*}$ & & & & & & & & & & & & & \\
\hline Ostrya carpinifolia & $\overline{3}^{*}$ & & & & & & & & & & & $3^{*}$ & & & & & & & \\
\hline Ostrya scholzii & $32^{\star}$ & & & & & & & & & $32^{*}$ & & & & & & & & & \\
\hline Paliurus sibiricus & $1^{*}$ & & & & & & & & & & & $1^{*}$ & & & & & & & \\
\hline Pterocarya limburgensis & $5^{*}$ & & & & & $5^{*}$ & & & & & & & & & & & & & \\
\hline Quercus robur & 1 & & & & & & & & & 1 & & 1 & & 1 & & & & & \\
\hline Rubus laticostatus & 1 & & & & & 1 & & 1 & & 1 & & 1 & & 1 & & 1 & & & \\
\hline Sequoia langsdorfi & $44^{\star}$ & & & & & $44^{*}$ & & & & & & & & & & & & & \\
\hline Sorbus aria & $1^{*}$ & & & & & & & & & & & $1 *$ & & & & & & & \\
\hline Sparganium haentzschelii & $1^{\star}$ & & & $1^{\star}$ & & & & & & & & & & & & & & & \\
\hline Styrax maximus & $1^{*}$ & & & & & & & & & & & $1 *$ & & & & & & & \\
\hline Symplocos germanica & $1^{*}$ & & & & & $1^{*}$ & & & & & & & & & & & & & \\
\hline Symplocos lignitarum & $10^{\star}$ & & & & & 10 & & & & $10^{*}$ & & & & & & & & & \\
\hline Symplocos salzhausenensis & $\underline{1}^{*}$ & & & & & $1^{*}$ & & & & & & & & & & & & & \\
\hline Symplocos schereri & $\frac{2}{2}$ & & & & & & & & & 2 & & 2 & & & & & & & \\
\hline Taxodium dubium & $1 \overline{7}^{\star}$ & & & & & $17^{\star}$ & & & & & & & & & & & & & \\
\hline Viscum sp. & $5^{*}$ & & & & & $5^{*}$ & & & & & & & & & & & & & \\
\hline Vitis lusatica & $2^{\star}$ & & & & & $2^{*}$ & & & & $2 \star$ & & & & & & & & & \\
\hline$?$ & 2 & & & & & & & & & & & & & & & & & & \\
\hline ? & 20 & & & & & & & & & & & & & & & & & & \\
\hline$\sum \operatorname{taxa}$ & 31 & - & & 3 & $10 \%$ & 16 & $52 \%$ & 3 & & 10 & $32 \%$ & 10 & $32 \%$ & 2 & & 1 & & 1 & \\
\hline$\Sigma$ characteristic taxa & 23 & - & & 3 & $13 \%$ & 11 & $48 \%$ & - & & 4 & $17 \%$ & 5 & $22 \%$ & - & & - & & - & \\
\hline$\Sigma$ fruits and seeds & 202 & - & & 4 & & 128 & & 3 & & 75 & & 17 & & 2 & & 1 & & 2 & \\
\hline$\Sigma$ char. fruits and seeds & 173 & - & & 4 & $2 \%$ & 90 & $54 \%$ & - & & 67 & $39 \%$ & 11 & $6 \%$ & - & & - & & - & \\
\hline
\end{tabular}


Sample 8297 (continued)

\begin{tabular}{|c|c|c|c|c|c|c|c|c|c|c|c|c|c|c|c|}
\hline \multirow[t]{2}{*}{ Species } & & & \multicolumn{13}{|c|}{ Vegetational units } \\
\hline & & & 1 & & 2 & & 3 & 4 & & 5 & & 6 & $i$ & 8 & 9 \\
\hline Vegetation figures & & & & & 25 & & 154 & & & 88 & & 60 & & - & \\
\hline$\Sigma$ palaeotropic taxa & 9 & & & 1 & $3 \%$ & 6 & $19 \%$ & & 2 & $6 \%$ & 2 & $6 \%$ & & & \\
\hline$\Sigma$ pal. char. taxa & 8 & - & & 1 & $4^{0 / 6}$ & 5 & $22 \%$ & & 1 & $4 \%$ & 1 & $4 \%$ & & & \\
\hline$\Sigma$ pal. char. frts and seeds & 22 & - & & 1 & $1 \%$ & 10 & $6 \%$ & & 10 & $6 \%$ & 1 & $1 \%$ & & & \\
\hline Palaeotropic figures & & & & & 8 & & 47 & & & 16 & & 11 & & & \\
\hline Arctotertiary figures & & & & & 17 & & 107 & & & 72 & & 49 & & & \\
\hline
\end{tabular}

Sample 8300

\begin{tabular}{|c|c|c|c|c|c|c|c|c|c|c|c|c|c|c|c|c|c|c|}
\hline \multirow[t]{2}{*}{ Species } & & & \multicolumn{16}{|c|}{ Vegetational units } \\
\hline & & & 1 & & 2 & & 3 & & 4 & & 5 & & 6 & & 7 & 8 & & 9 \\
\hline Acanthopanax solutus & $\underline{2}^{*}$ & & & & & & & & & & & $2^{\star}$ & & & & & & \\
\hline Actinidia faveolata & $1^{*}$ & & & & & & & $1^{\star}$ & & & & & & & & & & \\
\hline Alnus sp. & 1 * & & & & & $1^{*}$ & & & & & & & & & & & & \\
\hline Ceratophyllum submersum & $2^{*}$ & $2^{*}$ & & & & & & & & & & & & & & & & \\
\hline Cladiocarya trebovensis & $\underline{3}^{*}$ & & & $\underline{3}^{*}$ & & & & & & & & & & & & & & \\
\hline Cladium reidiorum & $\underline{2}^{\star}$ & & & $\underline{2}^{\star}$ & & & & & & & & & & & & & & \\
\hline Empetrum nigrum & $\overline{1} *$ & & & & & 1 & & & & & & & & & & & $1^{\star}$ & \\
\hline Epacridicarpum mudense & $340^{*}$ & & & & & 340 & & & & & & & & & & & $340^{\star}$ & \\
\hline Eurya lusatica & $\underline{14}^{*}$ & & & & & $\underline{14}^{*}$ & & & & & & & & & & & & \\
\hline Eurya stigmosa & $\underline{26}^{*}$ & & & & & $\underline{26}^{*}$ & & & & & & & & & & & & \\
\hline Gaylussacia rhenana & 2 & & & & & & & & & & & & & 2 & & & 2 & \\
\hline Homalanthus costatus & $\underline{1}^{*}$ & & & & & $\underline{1}^{*}$ & & & & & & & & & & & & \\
\hline Ilex fortunensis & $\underline{1}^{*}$ & & & & & 1 & & & & & & $\underline{1}$ & & 1 & & & & \\
\hline Leucothoe narbonnensis & $\overline{1}$ & & & & & $\overline{1}$ & & & & 1 & & & & & & & 1 & \\
\hline Ostrya scholzii & $2^{*}$ & & & & & & & & & $2^{*}$ & & & & & & & & \\
\hline Pinaceae & 2 & & & & & 2 & & & & & & 2 & & 2 & & & 2 & \\
\hline Scindapsites crassus & $\underline{1}^{*}$ & & & $1^{*}$ & & & & & & & & & & & & & & \\
\hline Sequoia langsdorfii & $38^{*}$ & & & & & $38^{*}$ & & & & & & & & & & & & \\
\hline Sparganium haentzschelii & $1^{*}$ & & & $1^{\star}$ & & & & & & & & & & & & & & \\
\hline Symplocos salzhausenensis & $\underline{4}^{*}$ & & & & & $\underline{4}^{*}$ & & & & & & & & & & & & \\
\hline Tetrastigma lobata & $\underline{1}^{\star}$ & & & & & $\underline{1}$ & & & & $\underline{1}^{*}$ & & & & & & & & \\
\hline Vitis sp. & $\overline{1}$ & & & & & $\overline{1}$ & & & & $\overrightarrow{1}$ & & & & & & & & \\
\hline$?$ & 1 & & & & & & & & & & & & & & & & & \\
\hline ? & 1 & & & & & & & & & & & & & & & & & \\
\hline$?$ & 1 & & & & & & & & & & & & & & & & & \\
\hline$?$ & 1 & & & & & & & & & & & & & & & & & \\
\hline$?$ & 1 & & & & & & & & & & & & & & & & & \\
\hline$?$ & 1 & & & & & & & & & & & & & & & & & \\
\hline$\Sigma$ taxa & 28 & 1 & $4 \%$ & 4 & $14 \%$ & 13 & $46 \%$ & 1 & $4 \%$ & 4 & $14 \%$ & 3 & $11 \%$ & 3 & & & 6 & $21 \%$ \\
\hline$\Sigma$ characteristic taxa & 17 & 1 & $6 \%$ & 4 & $24 \%$ & 6 & $35 \%$ & 1 & $6 \%$ & 2 & $12 \%$ & 1 & $6 \%$ & & & & 2 & $12 \%$ \\
\hline$\Sigma$ fruits and seeds & 453 & 2 & & 7 & & 432 & & 1 & & 5 & & 5 & & 5 & & & 346 & \\
\hline$\Sigma$ char fruits and seeds & 440 & 2 & $x$ & 7 & $2 \%$ & 84 & $19 \%$ & 1 & $x$ & 3 & $1 \%$ & 2 & $=$ & & & & 341 & $77 \%$ \\
\hline Vegetation figures & & & 10 & & 40 & & 100 & & 10 & & 27 & & 17 & & & & & 110 \\
\hline I palaeotropic taxa & 11 & & & 3 & $11 \%$ & 6 & $21 \%$ & - & & 1 & $4 \%$ & 2 & $7 \%$ & 1 & & & 1 & $4 \%$ \\
\hline$\Sigma$ pal. char. taxa & 10 & - & & 3 & $18 \%$ & 3 & $18 \%$ & - & & 1 & $6 \%$ & 1 & $6 \%$ & & & & 1 & $6 \%$ \\
\hline$\Sigma$ pal. char. frts and seeds & 394 & $\cdots$ & & 6 & $1 \%$ & 44 & $10 \%$ & -- & & 1 & x & 2 & $x$ & & & & 340 & $77 \%$ \\
\hline Palaeotropic figures & & & -. & & 30 & & 49 & & & & 10 & & 13 & & & & & 87 \\
\hline Arctotertiary figures & & & 10 & & 10 & & 51 & & 10 & & 17 & & 4 & & & & & 23 \\
\hline
\end{tabular}


Sample 8334

\begin{tabular}{|c|c|c|c|c|c|c|c|c|c|c|c|c|c|c|c|c|c|c|c|}
\hline \multirow{2}{*}{ Species } & & & \multicolumn{17}{|c|}{ Vegetational units } \\
\hline & & & 1 & & 2 & & 3 & & 4 & & 5 & & 6 & & 7 & & 8 & & 9 \\
\hline Alisma plantago-aquatica & $1 *$ & & & $1^{*}$ & & & & & & & & & & & & & & & \\
\hline Carex acuta & $1^{\star}$ & & & $1^{*}$ & & & & & & & & & & & & & & & \\
\hline Carex flagellata & $2^{*}$ & & & $2 *$ & & & & & & & & & & & & & & & \\
\hline Decodon globosus & $1^{\star}$ & & & $1^{*}$ & & & & & & & & & & & & & & & \\
\hline Magnolia burseracea & $1^{*}$ & & & & & $\underline{1}^{*}$ & & & & & & & & & & & & & \\
\hline Potamogeton sp. & $\overline{2}^{\star}$ & $2^{\star}$ & & & & & & & & & & & & & & & & & \\
\hline Scirpus melanospermus & $84^{*}$ & & & $84^{*}$ & & & & & & & & & & & & & & & \\
\hline Scirpus tabernaemontani & $1^{*}$ & & & $1^{*}$ & & & & & & & & & & & & & & & \\
\hline Sium latifolium & $1^{*}$ & & & $1^{\star}$ & & & & & & & & & & & & & & & \\
\hline Spirematospermum wetzleri & $\underline{20}^{*}$ & & & $\underline{20^{*}}$ & & & & & & & & & & & & & & & \\
\hline$?$ & $\overline{1}$ & & & & & & & & & & & & & & & & & & \\
\hline$\Sigma$ taxa & 11 & 1 & $9 \%$ & 8 & $73 \%$ & 1 & $9 \%$ & - & & - & & - & & - & & - & & - & \\
\hline$\Sigma$ characteristic taxa & 10 & 1 & $10 \%$ & 8 & $80 \%$ & 1 & $10 \%$ & - & & - & & - & & - & & - & & - & \\
\hline$\Sigma$ fruits and seeds & 115 & 2 & & 111 & & 1 & & - & & - & & - & & - & & - & & - & \\
\hline$\Sigma$ char. fruits and seeds & 114 & 2 & $2 \%$ & 111 & $97 \%$ & 1 & $1 \%$ & - & & - & & - & & - & & - & & - & \\
\hline Vegetation figures & & & 21 & & 250 & & 20 & & - & & - & & - & & - & & - & & - \\
\hline$\Sigma$ palaeotropic taxa & 2 & - & & 1 & $9 \%$ & 1 & $9 \%$ & - & & - & & - & & - & & - & & -- & \\
\hline$\Sigma$ pal. char. taxa & 2 & - & & 1 & $10 \%$ & 1 & $10 \%$ & - & & - & & - & & - & & - & & - & \\
\hline$\Sigma$ pal. char. frts and sds & 21 & - & & 20 & $18 \%$ & 1 & $1 \%$ & - & & - & & - & & - & & - & & - & \\
\hline Palaeotropic figures & & & - & & 37 & & 20 & & - & & - & & - & & - & & - & & - \\
\hline Arctotertiary figures & & & 21 & & 213 & & - & & - & & - & & - & & - & & - & & - \\
\hline
\end{tabular}

\section{Sample 8335}

\begin{tabular}{|c|c|c|c|c|c|c|c|c|c|c|c|c|c|c|c|c|c|c|c|}
\hline \multirow[t]{2}{*}{ Species } & & & \multicolumn{17}{|c|}{ Vegetational units } \\
\hline & & & 1 & & 2 & & 3 & & 4 & & 5 & & 6 & & 7 & & 8 & & 9 \\
\hline Acer sp. & 1 & & & & & & & 1 & & 1 & & & & & & & & & \\
\hline Alnus sp. & $11^{*}$ & & & & & $11^{\star}$ & & & & & & & & & & & & & \\
\hline Carex acuta & $7^{\star}$ & & & $7^{\star}$ & & & & & & & & & & & & & & & \\
\hline Carex Ragellata & $1 *$ & & & $1^{*}$ & & & & & & & & & & & & & & & \\
\hline Carex sp. div. & 1 & & & & & & & & & & & & & & & & & & \\
\hline Caricoidea jugata & $\underline{4}^{*}$ & & & $4^{*}$ & & & & & & & & & & & & & & & \\
\hline Cladiocarya trebovensis & $\overline{3}^{*}$ & & & $\underline{3}^{*}$ & & & & & & & & & & & & & & & \\
\hline Cladium reidiorum & $\overline{1}^{*}$ & & & $\overline{1}^{*}$ & & & & & & & & & & & & & & & \\
\hline Crataegus nodulosa & $\overrightarrow{4}$ & & & & & & & 4 & & 4 & & 4 & & & & & & & \\
\hline Empetrum nigrum & $1^{*}$ & & & & & 1 & & & & & & & & & & & & $1^{*}$ & \\
\hline Epacridicarpum mudense & $167^{\star}$ & & & & & 167 & & & & & & & & & & & & $167^{\star}$ & \\
\hline Eurya stigmosa & $\underline{22}^{\star}$ & & & & & $22^{\star}$ & & & & & & & & & & & & & \\
\hline Ilex protogaea & $1 *$ & & & & & $1^{*}$ & & & & & & & & & & & & & \\
\hline Liriodendron geminatum & $2^{\star}$ & & & & & 2 & & & & $2^{\star}$ & & & & & & & & & \\
\hline Myrica ceriferiformis & $4^{*}$ & & & & & $4^{*}$ & & & & & & & & & & & & & \\
\hline Myrica minima & $1^{*}$ & & & & & $1^{\star}$ & & & & & & & & & & & & & \\
\hline Ostrya carpinifolia & $2^{*}$ & & & & & & & & & & & $2^{*}$ & & & & & & & \\
\hline Ostrya scholzii & $34^{\star}$ & & & & & & & & & $34^{\star}$ & & & & & & & & & \\
\hline Rubus laticostatus & 1 & & & & & 1 & & 1 & & 1 & & 1 & & 1 & & 1 & & & \\
\hline Sequoia langsdorfii & $209^{*}$ & & & & & $209^{\star}$ & & & & & & & & & & & & & \\
\hline Symplocos lignitarum & $\underline{1}^{*}$ & & & & & $\underline{1}$ & & & & $\underline{1}^{*}$ & & & & & & & & & \\
\hline Symplocos minutula & $1^{*}$ & & & & & $\underline{1}^{*}$ & & & & & & & & & & & & & \\
\hline Symplocos salzhausenensis & $\overline{1}^{*}$ & & & & & $\overline{1} *$ & & & & & & & & & & & & & \\
\hline Vaccinium miocenicum & 1 & & & & & & & & & & & & & 1 & & & & 1 & \\
\hline Viola canina & $1 *$ & & & & & & & $1^{*}$ & & & & & & & & & & & \\
\hline Ziziphus striata & $1^{*}$ & & & & & $1^{\star}$ & & & & & & & & & & & & & \\
\hline$?$ & 5 & & & & & & & & & & & & & & & & & & \\
\hline$\Sigma$ taxa & 27 & - & & 5 & $19 \%$ & 14 & $52 \%$ & 4 & $15 \%$ & 6 & $22 \%$ & 4 & $15 \%$ & 2 & & 1 & & 3 & $11 \%$ \\
\hline$\Sigma$ characteriatic taxa & 21 & - & & 5 & $24 \%$ & 9 & $43 \%$ & 1 & $5 \%$ & 3 & $14 \%$ & 1 & $5 \%$ & - & & - & & 2 & $10 \%$ \\
\hline$\Sigma$ fruits and seeds & 488 & - & & 16 & & 423 & & 7 & & 43 & & 8 & & 2 & & 1 & & 169 & \\
\hline$\Sigma$ char. fruits and seeds & 475 & - & & 16 & $3 \%$ & 251 & $53 \%$ & 1 & $x$ & 37 & $8 \%$ & 2 & $x$ & - & & - & & 168 & $35 \%$ \\
\hline
\end{tabular}


Sample 8335 (continued)

\begin{tabular}{|c|c|c|c|c|c|c|c|c|c|c|c|c|c|c|}
\hline \multirow[t]{2}{*}{ Species } & & \multicolumn{13}{|c|}{ Vegetational units } \\
\hline & & 1 & & 2 & & 3 & 4 & & 5 & ti & 7 & 8 & & 9 \\
\hline Vegetation figures & & & & 41 & & 148 & 20 & & 44 & 20 & & & & 56 \\
\hline$\Sigma$ palaeotropic taxa & 8 & & 3 & $11 \%$ & 5 & $19 \%$ & & 1 & $4 \%$ & & & & 1 & $4 \%$ \\
\hline$\Sigma$ pal, char taxa & 8 & & 3 & $14 \%$ & 3 & $14 \%$ & & 1 & $5 \%$ & & & & 1 & $5 \%$ \\
\hline Epal. char frts and seeds & 200 & & 8 & $2 \%$ & 24 & $5 \%$ & & 1 & $x$ & & & & 167 & $35 \%$ \\
\hline Palaeotropic figures & & & & 27 & & 38 & $\cdots$ & & 9 & & & - & & 44 \\
\hline Arctotertiary figures & & & & 14 & & 110 & 20 & & 35 & 20 & & & & 12 \\
\hline
\end{tabular}

\section{Sample 8336}

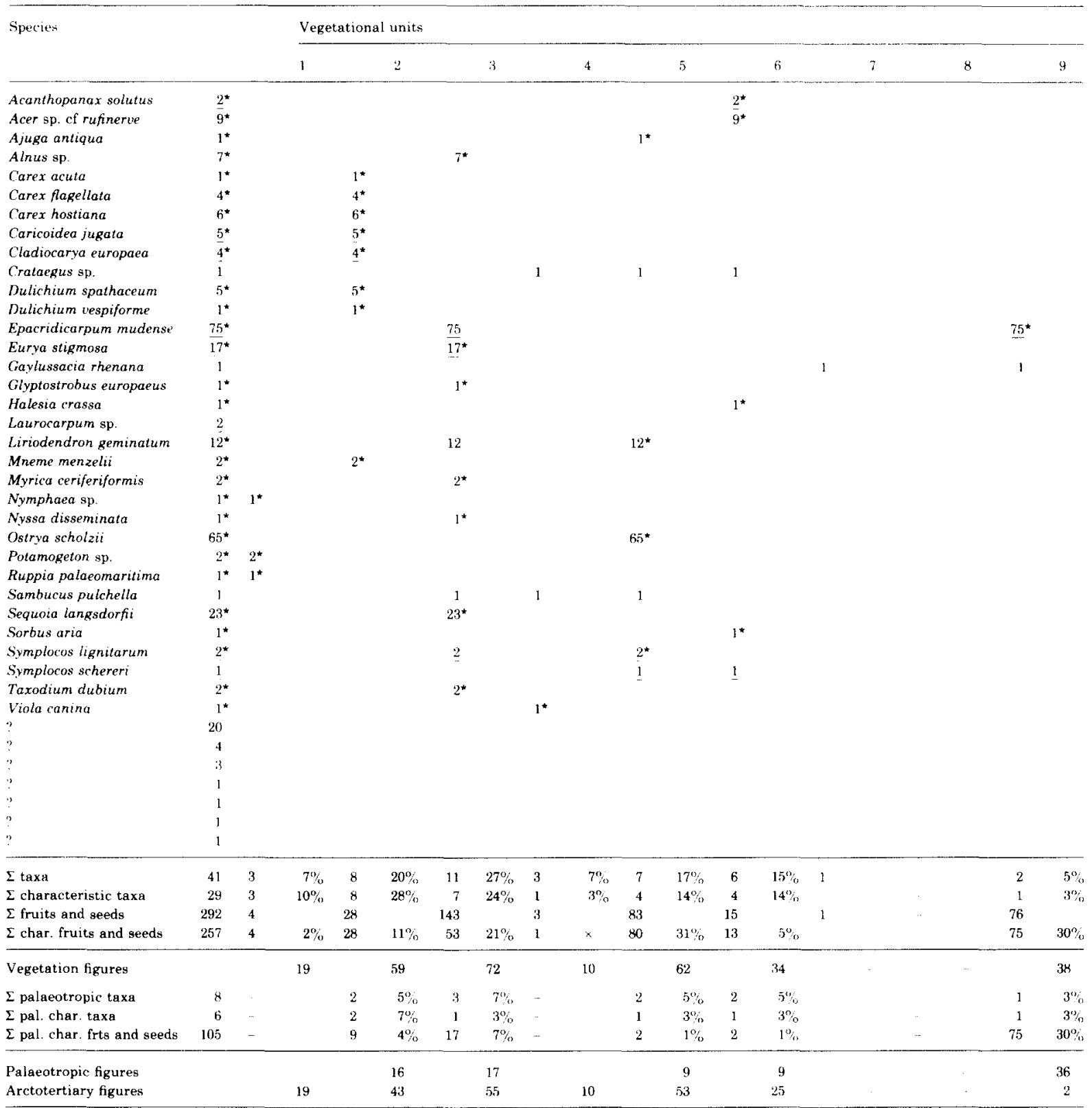


Sample 13285

\begin{tabular}{|c|c|c|c|c|c|c|c|c|c|c|c|c|c|c|c|c|c|c|c|}
\hline \multirow[t]{2}{*}{ Species } & & & \multicolumn{17}{|c|}{ Vegetational units } \\
\hline & & & 1 & & 2 & & 3 & & 4 & & 5 & & 6 & & 7 & & 8 & & 9 \\
\hline Alnus sp. & $1^{*}$ & & & & & $1^{\star}$ & & & & & & & & & & & & & \\
\hline Arctostaphyloides menzelii & $\underline{5}^{\star}$ & & & & & $\underline{5}$ & & & & & & & & & & & & $\underline{5}^{*}$ & \\
\hline Asimina brownii & $\overline{1}^{*}$ & & & & & & & & & $1^{\star}$ & & & & & & & & & \\
\hline Carex sp. div. & 3 & & & & & & & & & & & & & & & & & & \\
\hline Caricoidea jugata & $\underline{1}^{*}$ & & & $\underline{1}^{*}$ & & & & & & & & & & & & & & & \\
\hline Cladiocarya trebovensis & $\underline{2}^{\star}$ & & & $\underline{2}^{*}$ & & & & & & & & & & & & & & & \\
\hline Comptonia costata & $\overline{1}^{*}$ & & & & & & & & & & & & & & & $1^{*}$ & & & \\
\hline Distylium uralense & $11^{\star}$ & & & & & $11^{*}$ & & & & & & & & & & & & & \\
\hline Epacridicarpum mudense & $37^{\star}$ & & & & & 37 & & & & & & & & & & & & $\underline{37^{*}}$ & \\
\hline Epipremnites ornatus & $\underline{3}^{*}$ & & & $\underline{3}^{\star}$ & & & & & & & & & & & & & & & \\
\hline Eurya stigmosa & $\overline{\overline{7}}^{\star}$ & & & & & $\underline{7}^{*}$ & & & & & & & & & & & & & \\
\hline Homalanthus costatus & $\underline{5 \overline{2}^{\star}}$ & & & & & $\underline{5 \overline{2}}^{\star}$ & & & & & & & & & & & & & \\
\hline Leucothoe narbonnensis & $\overline{6}$ & & & & & $\overline{6}$ & & & & 6 & & & & & & & & 6 & \\
\hline Magnolia burseracea & $9^{*}$ & & & & & $\underline{9}^{*}$ & & & & & & & & & & & & & \\
\hline Magnolia lusatica & $\underline{2}^{\star}$ & & & & & $\underline{2}^{\star}$ & & & & & & & & & & & & & \\
\hline Mastixia thomsonii & $\underline{25}$ & & & & & $\underline{2 \overline{5}}$ & & & & $\underline{25}^{*}$ & & & & & & & & & \\
\hline Myrica minima & $\overline{1}{ }^{*}$ & & & & & $\overline{1}^{\star}$ & & & & & & & & & & & & & \\
\hline Palliopora symplocoides & 1 & & & & & & & $\underline{1}$ & & $\underline{1}$ & & $\underline{1}$ & & & & & & & \\
\hline Pinaceae & $\overrightarrow{1}$ & & & & & 1 & & & & & & $\overline{1}$ & & 1 & & & & 1 & \\
\hline Rubus laticostatus & 1 & & & & & 1 & & 1 & & 1 & & 1 & & 1 & & 1 & & & \\
\hline Scirpus melanospermus & $1^{*}$ & & & $1^{*}$ & & & & & & & & & & & & & & & \\
\hline Sequoia langsdorfii & $218^{*}$ & & & & & $218^{*}$ & & & & & & & & & & & & & \\
\hline Sphenotheca incurva & $\underline{1}$ & & & & & & & 1 & & 1 & & $\underline{1}$ & & & & & & & \\
\hline Stewartia beckeriana & $\overline{1}^{*}$ & & & & & & & & & & & $\overline{1}^{\star}$ & & & & & & & \\
\hline Symplocos germanica & $46^{*}$ & & & & & $\underline{46}^{\star}$ & & & & & & & & & & & & & \\
\hline Symplocos lignitarum & $\underline{33}^{*}$ & & & & & $\underline{\mathbf{3 3}}$ & & & & $\underline{33}^{*}$ & & & & & & & & & \\
\hline Symplocos salzhausenensis & $\underline{1}^{*}$ & & & & & $\underline{1}^{*}$ & & & & & & & & & & & & & \\
\hline Tetrastigma lobata & $\underline{\overline{2}}^{\star}$ & & & & & $\overline{2}$ & & & & $\underline{2}^{*}$ & & & & & & & & & \\
\hline$?$ & $\overline{4}$ & & & & & & & & & & & & & & & & & & \\
\hline$\Sigma$ taxa & 29 & - & & 4 & $14 \%$ & 18 & $62 \%$ & 3 & & 8 & $28 \%$ & 5 & $17 \%$ & 2 & & 2 & $7 \%$ & 4 & $14 \%$ \\
\hline$\Sigma$ characteristic taxa & 22 & - & & 4 & $18 \%$ & 10 & $45 \%$ & - & & 4 & $18 \%$ & 1 & $5 \%$ & - & & 1 & $5 \%$ & 2 & $9 \%$ \\
\hline$\Sigma$ fruits and seeds & 477 & - & & 7 & & 458 & & 3 & & 70 & & 5 & & 2 & & 2 & & 49 & \\
\hline$\Sigma$ char. fruits and seeds & 460 & - & & 7 & $2 \%$ & 348 & $76 \%$ & - & & 61 & $13 \%$ & 1 & $x$ & - & & 1 & $x$ & 42 & $9 \%$ \\
\hline Vegetation figures & & & - & & 34 & & 183 & & - & & 59 & & 22 & & - & & 12 & & 32 \\
\hline$\Sigma$ palaeotropic taxa & 16 & - & & 3 & $10 \%$ & 11 & $38 \%$ & 2 & & 5 & $17 \%$ & 2 & $7 \%$ & - & & - & & 2 & $7 \%$ \\
\hline$\Sigma$ pal. char. taxa & 14 & - & & 3 & $14 \%$ & 6 & $27 \%$ & - & & 3 & $14 \%$ & - & & - & & - & & 2 & $9 \%$ \\
\hline$\Sigma$ pal. char. frts and seeds & 225 & - & & 6 & $1 \%$ & 117 & $25 \%$ & - & & 60 & $13 \%$ & - & & - & & - & & 42 & $9 \%$ \\
\hline Palaeotropic figures & & & - & & 25 & & 91 & & - & & 44 & & 7 & & - & & - & & 25 \\
\hline Arctotertiary figures & & & - & & 9 & & 92 & & - & & 15 & & 15 & & - & & 12 & & 7 \\
\hline
\end{tabular}

\section{Sample 13286}

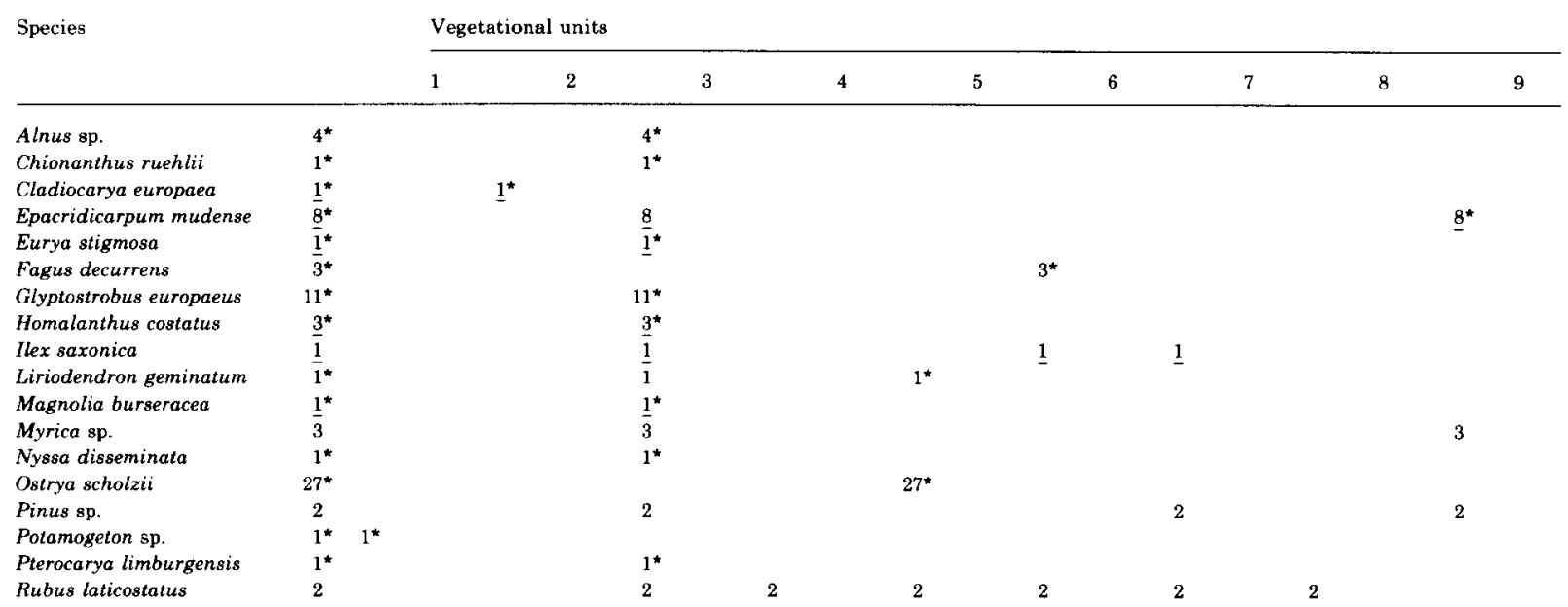


Sample 13286 (continued)

\begin{tabular}{|c|c|c|c|c|c|c|c|c|c|c|c|c|c|c|c|c|c|c|c|}
\hline \multirow[t]{2}{*}{ Species } & & & \multicolumn{17}{|c|}{ Vegetational units } \\
\hline & & & 1 & & 2 & & 3 & & 4 & & 5 & & 6 & & 7 & & 8 & & 9 \\
\hline Sequoia langsdorfii & $32^{\star}$ & & & & & $32^{\star}$ & & & & & & & & & & & & & \\
\hline Symplocos germanica & $1^{*}$ & & & & & $1^{*}$ & & & & & & & & & & & & & \\
\hline Symplocos lignitarum & $\underline{9}^{*}$ & & & & & $\bar{g}$ & & & & $9^{*}$ & & & & & & & & & \\
\hline Symplocos minutula & $\underline{1}^{*}$ & & & & & $\underline{i}^{*}$ & & & & & & & & & & & & & \\
\hline Symplocos pseudogregaria & $\overline{2}$ & & & & & $\overline{\overline{2}}$ & & & & $2^{\star}$ & & & & & & & & & \\
\hline Symplocos schereri & 1 & & & & & & & & & $\overline{1}$ & & 1 & & & & & & & \\
\hline Taxodium dubium & 3 & & & & & $3^{*}$ & & & & & & & & & & & & & \\
\hline Tetrastigma lobata & $1^{*}$ & & & & & 1 & & & & $\underline{1}^{*}$ & & & & & & & & & \\
\hline Toddalia rhenana & $\overline{1}$ * & & & & & $1 *$ & & & & & & & & & & & & & \\
\hline Vitis sp. & $t$ & & & & & 1 & & & & 1 & & & & & & & & & \\
\hline$?$ & 11 & & & & & & & & & & & & & & & & & & \\
\hline ? & 3 & & & & & & & & & & & & & & & & & & \\
\hline$?$ & 1 & & & & & & & & & & & & & & & & & & \\
\hline$\Sigma \operatorname{taxa}$ & 31 & 1 & $3 \%$ & 1 & $3 \%$ & 23 & $74 \%$ & 1 & & 8 & $26 \%$ & 4 & $13 \%$ & 3 & & 1 & & 3 & $10 \%$ \\
\hline$\Sigma$ characteristic taxa & 22 & 1 & $5 \%$ & 1 & $5 \%$ & 13 & $59 \%$ & - & & 5 & $23 \%$ & 1 & $5 \%$ & & & & & 1 & $5 \%$ \\
\hline$\Sigma$ fruits and seeds & 139 & 1 & & 1 & & 91 & & 2 & & 44 & & 7 & & 5 & & 2 & & 13 & \\
\hline$\Sigma$ char. fruits and seeds & 114 & 1 & $1 \%$ & 1 & $1 \%$ & 61 & $54 \%$ & - & & 40 & $35 \%$ & 3 & $3 \%$ & & & & & 8 & $7 \%$ \\
\hline Vegetation figures & & & 9 & & 9 & & 187 & & - & & 84 & & $2 !$ & & & &.. & & 22 \\
\hline$\Sigma$ palaeotropic taxa & 14 & & & 1 & $3 \%$ & 12 & $39 \%$ & - & & 4 & $13 \%$ & 2 & $6^{j}$ & 1 & & & & 1. & $3^{\alpha} \%$ \\
\hline$\sum$ pal. char. taxa & 12 & -- & & 1 & $5 \%$ & 7 & $32 \%$ & - & & 3 & $14 \%$ & & & & & & & 1 & $5 \%$ \\
\hline$\Sigma$ pal. char. frts and seeds & 29 & & & 1 & $1 \%$ & 9 & $8 \%$ & - & & 12 & $11 \%$ & & & & & & & 8 & $7 \%$ \\
\hline Palaeotropic figures & & & & & 9 & & 79 & & $\ldots$ & & 38 & & 6 & & & & & & 15 \\
\hline Arctotertiary figures & & & 9 & & -- & & 108 & & & & 46 & & 15 & & & & & & 7 \\
\hline
\end{tabular}

\section{Sample 14399}

\begin{tabular}{|c|c|c|c|c|c|c|c|c|c|c|c|c|c|c|c|c|c|c|}
\hline \multirow[t]{2}{*}{ Species } & & & \multicolumn{16}{|c|}{ Vegetational units } \\
\hline & & 1 & 1 & 2 & & 3 & & 4 & & 5 & & 6 & & 7 & & 8 & & 9 \\
\hline Carex hostiana & $8^{*}$ & & $8^{*}$ & & & & & & & & & & & & & & & \\
\hline Caricoidea jugata & $11^{*}$ & & $11^{*}$ & & & & & & & & & & & & & & & \\
\hline Cladiocarya europaea & $\underline{2}^{\star}$ & & $2^{*}$ & & & & & & & & & & & & & & & \\
\hline Cladiocarya trebovensis & $\underline{1}^{*}$ & & $\overline{1}^{*}$ & & & & & & & & & & & & & & & \\
\hline Chionanthus ruehlii & $5 *$ & & & & $5^{\star}$ & & & & & & & & & & & & & \\
\hline Empetrum nigrum & $1^{*}$ & & & & $\overline{1}$ & & & & & & & & & & & & $1^{\star}$ & \\
\hline Eurya stigmosa & $575^{*}$ & & & & $575^{\star}$ & & & & & & & & & & & & & \\
\hline Glyptostrobus europaeus & $47^{*}$ & & & & $47^{\star}$ & & & & & & & & & & & & & \\
\hline Homalanthus costatus & $\underline{4}^{*}$ & & & & $4^{\star}$ & & & & & & & & & & & & & \\
\hline llex saxonica & $\underline{\overline{2}}$ & & & & $\underline{2}$ & & & & & & $\underline{2}$ & & 2 & & & & & \\
\hline Magnolia burseracea & $\underline{8}^{*}$ & & & & $\bar{g}^{*}$ & & & & & & & & & & & & & \\
\hline Myrica ceriferiformis & $51^{*}$ & & & & $51^{\star}$ & & & & & & & & & & & & & \\
\hline Myrica minima & $15^{*}$ & & & & $15^{\star}$ & & & & & & & & & & & & & \\
\hline Ostrya scholzii & $1 *$ & & & & & & & & $1^{*}$ & & & & & & & & & \\
\hline Rubus laticostatus & 12 & & & & 12 & & 12 & & 12 & & 12 & & 12 & & 12 & & & \\
\hline Sequoia langsdorfii & $208^{*}$ & & & & $208^{\star}$ & & & & & & & & & & & & & \\
\hline Sorbus herzogenrathensis & $7^{*}$ & & & & $7^{\star}$ & & & & & & & & & & & & & \\
\hline Symplocos germanica & $\underline{11}$ * & & & & $11^{\star}$ & & & & & & & & & & & & & \\
\hline Symplocos gothanii & $38 *$ & & & & $38^{*}$ & & & & & & & & & & & & & \\
\hline Symplocos lignitarum & $2^{*}$ & & & & 2 & & & & $2^{\star}$ & & & & & & & & & \\
\hline Umbelliferopsis molassicus & $3^{*}$ & & $3^{\star}$ & & & & & & & & & & & & & & & \\
\hline Vitis sp. & 1 & & & & 1 & & & & 1 & & & & & & & & & \\
\hline$?$ & 100 & & & & & & & & & & & & & & & & & \\
\hline$\Sigma \operatorname{tax} \theta$ & 23 & & 5 & $22 \%$ & 16 & $70 \%$ & 1 & & 4 & $17 \%$ & 2 & & 2 & & 1 & & 1 & $4 \%$ \\
\hline$\Sigma$ characteristic taxa & 19 & & 5 & $26 \%$ & 11 & $58 \%$ & - & & 2 & $11 \%$ & . & & & & & & 1 & $5 \%$ \\
\hline$\Sigma$ fruits and seeds & 1113 & .. & 25 & & 985 & & 12 & & 16 & & 14 & & 14 & & 14 & & 1 & \\
\hline$\Sigma$ char. fruits and seeds & 998 & - & 25 & $3 \%$ & 969 & $97 \%$ & - & & 3 & $\times$ & - & & & & $\ldots$ & & 1 & $\times$ \\
\hline
\end{tabular}


Sample 14399 (continued)

\begin{tabular}{|c|c|c|c|c|c|c|c|c|c|c|c|c|c|c|c|c|c|c|c|}
\hline \multirow[t]{2}{*}{ Species } & & & \multicolumn{17}{|c|}{ Vegetational units } \\
\hline & & & 1 & & 2 & & 3 & & 4 & & $\mathbf{5}$ & & 6 & & 7 & & 8 & & 9 \\
\hline Vegetation figures & & & - & & 51 & & 225 & & - & & 28 & & - & & - & & - & & 9 \\
\hline I palaeotropic taxa & 11 & - & & 3 & $13 \%$ & 8 & $35 \%$ & - & & 1 & $4 \%$ & 1 & & 1 & & - & & - & \\
\hline$\Sigma$ pal. char. taxa & 10 & - & & 3 & $16 \%$ & 6 & $32 \%$ & - & & 1 & $5 \%$ & - & & - & & - & & - & \\
\hline$\Sigma$ pal. char. frts and seeds & 657 & - & & 14 & $1 \%$ & 641 & $64 \%$ & - & & 2 & $x$ & - & & - & & - & & - & \\
\hline Palaeotropic figures & & & - & & 30 & & 131 & & - & & 9 & & - & & - & & - & & - \\
\hline Arctotertiary figures & & & - & & 21 & & 94 & & - & & 19 & & - & & - & & - & & 9 \\
\hline
\end{tabular}

Sample 14400

\begin{tabular}{|c|c|c|c|c|c|c|c|c|c|}
\hline \multirow[t]{2}{*}{ Species } & \multicolumn{9}{|c|}{ Vegetational units } \\
\hline & 1 & 2 & 3 & 4 & 5 & 6 & 7 & 8 & 9 \\
\hline
\end{tabular}

Carex acutiformis

Carex hostiana

Caricoidea jugata

Empetrum nigrum

Eurya stigmosa

Glyptostrobus europaeus

Homalanthus costatus

Magnolia lignita

Myrica ceriferiformis

Myrice minime

Rubus laticostatus

Sequoia langsdorfii

Symplocos germanica

Symplocos gothanii

Symplocos lignitarum

Umbelliferopsis molassicus

$\begin{array}{ll}2^{*} & 2^{*} \\ 1^{*} & 1^{*} \\ 4^{*} & \underline{4}^{*}\end{array}$

$2^{*}$

*

2

2

$\frac{581^{*}}{11^{*}} \quad{\frac{581}{11^{*}}}^{*}$

$\frac{5^{*}}{6^{*}} \quad \frac{5}{6}^{*}$

$\frac{5^{*}}{6^{*}}$

$\begin{array}{ll}4^{*} & 4^{*} \\ 3^{*} & 3^{*}\end{array}$

$\Sigma$ taxa

$\Sigma$ characteristic taxa

$\Sigma$ fruits and seeds

$\Sigma$ char. fruits and seeds

9

$297^{\star}$

$\underline{1}^{*}$

$\begin{array}{lllllll}9 & 9 & 9 & 9 & 9 & 9\end{array}$

Vegetation figures

$\Sigma$ palaeotropic taxa

$\Sigma$ pal. char. taxa

$\Sigma$ pal. char. frts and seeds

$1^{*}$

\begin{tabular}{|c|c|c|c|c|c|c|c|c|c|c|c|c|c|}
\hline 16 & - & 4 & $26 \%$ & 12 & $75 \%$ & 1 & 2 & $13 \%$ & 1 & 1 & 1 & 1 & $6 \%$ \\
\hline 15 & - & 4 & $27 \%$ & 9 & $59 \%$ & - & 1 & $7 \%$ & - & - & - & 1 & $7 \%$ \\
\hline 945 & - & 7 & & 937 & & 9 & 10 & & 9 & 9 & 9 & 2 & \\
\hline 936 & - & 7 & $1 \%$ & 925 & $99 \%$ & - & 1 & $x$ & - & - & - & 2 & $x$ \\
\hline
\end{tabular}

Palaeotropic figures

Arctotertiary figures

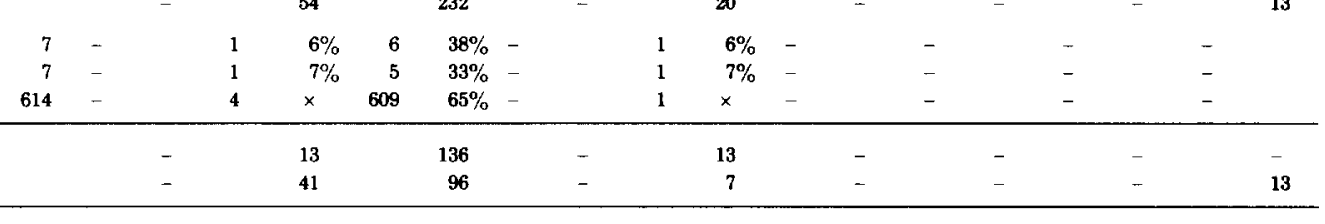

Sample 14401

Species Vegetational units

1

Arctostaphyloides menzelii

$\frac{30^{*}}{2^{*}} 2^{*}$
$3^{*}$
$2^{*}$
1
$\frac{91^{*}}{4^{*}}$
$\frac{42^{*}}{25^{*}}$
$1^{*}$
$108^{*}$
$2^{*}$
$2^{*}$
$\frac{60^{*}}{1^{*}}$

$2^{\star}$

Brasenia victoria

Carex acutiformis

Carex hostiana

Carex sp. div.

Caricoidea jugata

Cladiocarya trebovensis

Cladium reidiorum

Corema intermedia

Corylopsis urselensis

Cupressoconus rhenanus

Decodon globosus

Empetrum nigrum

Epacridicarpum mudense

Epipremnites ornatus

2

3

30

$\underline{30}^{*}$

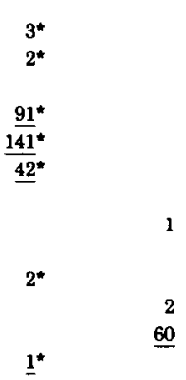

25*

$108^{*}$ 
Sample 14401 (continued)

\begin{tabular}{|c|c|c|c|c|c|c|c|c|c|c|c|c|c|c|c|c|c|c|c|}
\hline \multirow[t]{2}{*}{ Species } & & & \multicolumn{17}{|c|}{ Vegetational units } \\
\hline & & & 1 & & 2 & & 3 & & 4 & & $\tilde{5}$ & & 6 & & $i$ & & $x$ & & 9 \\
\hline Erica palaeoarborea & $99^{*}$ & & & & & & & & & & & & & & & & & $99^{\star}$ & \\
\hline Ericaceae, gen. et sp. indet. & $1309^{\star}$ & & & & & & & & & & & & & & & & & $309^{*}$ & \\
\hline Ericaceae, gen. et sp. indet & $2 \quad 14^{*}$ & & & & & & & & & & & & & & & & & $14^{*}$ & \\
\hline Eriophorum sp. & $1^{\star}$ & & & & & & & & & & & & & & & & & $1^{*}$ & \\
\hline Eurya stigmosa & $1^{\star}$ & & & & & $\underline{I}^{\star}$ & & & & & & & & & & & & & \\
\hline Glyplostrobus europaeus & $1 *$ & & & & & ]* & & & & & & & & & & & & & \\
\hline Homalanthus costatus & $\underline{2}^{*}$ & & & & & $2^{\star}$ & & & & & & & & & & & & & \\
\hline Hypericum sp. & 1 & & & 1 & & $i$ & & & & & & & & & & & & & \\
\hline Ilex protogaea & $1^{\star}$ & & & & & $1^{\star}$ & & & & & & & & & & & & & \\
\hline Myrica boveyana & $1^{*}$ & & & & & 1 & & & & & & & & & & & & $1^{*}$ & \\
\hline Myrica suppanii & $1^{*}$ & & & & & 1 & & & & & & & & & & & & $1^{*}$ & \\
\hline Pinaceae & 17 & & & & & 17 & & & & & & 17 & & 17 & & & & 17 & \\
\hline Pinus spinosa & 1 & & & & & 1 & & & & & & & & 1 & & & & 1 & \\
\hline Pinus thomasiana & 3 & & & & & 3 & & & & & & & & 3 & & & & is & \\
\hline Pinus uranii & 1.4 & & & & & 14 & & & & & & & & 14 & & & & 14 & \\
\hline Potamogeton sp. & $1^{\star}$ & $1^{\star}$ & & & & & & & & & & & & & & & & & \\
\hline Proserpinaca reticulata & $1^{\star}$ & & & & & ]$^{*}$ & & & & & & & & & & & & & \\
\hline Punica natans & $\underline{9}^{*}$ & & & & & & & & & & & $9^{\star}$ & & & & & & & \\
\hline Rhynchospora tertiaria & $34^{*}$ & & & & & & & & & & & & & & & & & $34^{*}$ & \\
\hline Ruppia palaeomaritima & $14^{*}$ & $14^{*}$ & & & & & & & & & & & & & & & & & \\
\hline Sambucus pulchella & 1 & & & & & 1 & & 1 & & 1 & & & & & & & & & \\
\hline Scirpus lacustris & $4^{*}$ & & & $4^{\star}$ & & & & & & & & & & & & & & & \\
\hline Scirpus melanospermus & $3^{*}$ & & & $3^{*}$ & & & & & & & & & & & & & & & \\
\hline Scirpus tabernaemontani & $5^{*}$ & & & $5 *$ & & & & & & & & & & & & & & & \\
\hline Sequoia langsdorfii & $44^{*}$ & & & & & $\$ 4^{\star}$ & & & & & & & & & & & & & \\
\hline Stratiotes tuberculatus & $1^{\star}$ & $1^{*}$ & & & & & & & & & & & & & & & & & \\
\hline Symplocos pseudogregaria & $1^{*}$ & & & & & 1 & & & & $l^{*}$ & & & & & & & & & \\
\hline Viola canina & $3^{*}$ & & & & & & & $3^{*}$ & & & & & & & & & & & \\
\hline$?$ & 40 & & & & & & & & & & & & & & & & & & \\
\hline E taxa & 44 & 4 & $9 \%$ & 11 & $25 \%$ & 19 & $43 \%$ & 2 & $5 \%$ & 2 & $5_{n}^{\prime}{ }_{n}$ & 2 & $5^{m}$ & 5 & $11 \%$ & 1 & $2 \%$ & 15 & $34^{\prime \prime}$ \\
\hline$\Sigma$ characteristic taxa & 36 & 4 & $11 \%$ & 10 & $28^{\circ} \%$ & 6 & $17 \%$ & 1 & $3 \%$ & 1 & $3^{n}$ & 1 & $3 \%$ & 1 & $3 \%$ & 1 & $3 \%$ & 11 & $31 \%$ \\
\hline$\Sigma$ fruits and seeds & 1138 & 18 & & 295 & & 183 & & 4 & & 2 & & 26 & & 143 & & 25 & & 587 & \\
\hline$\Sigma$ char. fruits and seeds & 1059 & 18 & $2 \%$ & 294 & $28 \%$ & 50 & $5 \%$ & 3 & $x$ & 1 & $x$ & 9 & $1 \%$ & 108 & $10 \%$ & 25 & $2^{1 \%}$ & 552 & $52 \%$ \\
\hline Vegetation figures & & & 22 & & 81 & & 65 & & 8 & & 8 & & 9 & & 24 & & 7 & & 117 \\
\hline$\Sigma$ palaeotropic taxa & 12 & & & 4 & $9 \%$ & $i$ & $16 \%$ & & & 1 & $2 \%$ & 1 & $2^{\infty}$ & & & & & 4 & $9 \%$ \\
\hline$\Sigma$ pal. char taxa & 12 & - & & 4 & $11 \%$ & 2 & $6 \%$ & & & 1 & $3 \%$ & 1 & $3_{\%}^{\circ}$ & & & & & 4 & $11 \%$ \\
\hline$\Sigma$ pal. char. frts and seeds & 380 & - & & 275 & $26 \%$ & 3 & $\times$ & & & 1 & ${ }^{x}$ & 9 & $1^{3}=$ & & & & & 92 & $9_{\%}^{\circ}$ \\
\hline Palaeotropic figures & & & & & 46 & & 22 & & & & 5 & & 6 & & & & & & 29 \\
\hline Arctotertiary figures & & & 22 & & 35 & & 43 & & 8 & & 3 & & 3 & & 24 & & 7 & & 88 \\
\hline
\end{tabular}

Sample 14402

\begin{tabular}{|c|c|c|c|c|c|c|c|c|c|c|c|c|c|c|c|c|c|c|}
\hline \multirow[t]{2}{*}{ Species } & & \multicolumn{17}{|c|}{ Vegetational units } \\
\hline & & 1 & & 2 & & 3 & & 4 & & 5 & & ti & & 7 & & $x$ & & 9 \\
\hline Caricoldea jugata & $4^{*}$ & & $\underline{4}^{*}$ & & & & & & & & & & & & & & & \\
\hline Chionanthus ruehlii & $\underline{3}^{*}$ & & & & $\underline{\beta}^{*}$ & & & & & & & & & & & & & \\
\hline Empetrum nigrum & $\overline{3} *$ & & & & $\overline{3}$ & & & & & & & & & & & & $3^{\star \mathbf{r}}$ & \\
\hline Eomastixia persicoides & $3^{\star}$ & & & & $\underline{3}^{*}$ & & & & & & & & & & & & & \\
\hline Eurya stigmosa & $34 \overline{7}^{*}$ & & & & $347^{*}$ & & & & & & & & & & & & & \\
\hline Glyptostrobus europaeus & $10^{\star}$ & & & & $10^{*}$ & & & & & & & & & & & & & \\
\hline Homalanthus costatus & $\underline{6}^{\star}$ & & & & $6^{*}$ & & & & & & & & & & & & & \\
\hline Liriodendron geminatum & $\overline{1}$ & & & & 1 & & & & $1^{\star}$ & & & & & & & & & \\
\hline Magnolia lignita & $\underline{15}$ & & & & $15^{*}$ & & & & & & & & & & & & & \\
\hline Magnolia sp. & $\underline{2}$ & & & & 2 & & & & & & & & & & & & & \\
\hline Mastixia thomsonii & $\underline{1}^{*}$ & & & & I & & & & $\underline{1}^{*}$ & & & & & & & & & \\
\hline Myrica ceriferiformis & $10^{\star}$ & & & & $10^{*}$ & & & & & & & & & & & & & \\
\hline Myrica minima & $54^{*}$ & & & & $54^{\star}$ & & & & & & & & & & & & & \\
\hline Punica natans & $10^{*}$ & & & & & & & & & & $\underline{10}^{\star}$ & & & & & & & \\
\hline Rubus laticostatus & $\overline{6}$ & & & & 6 & & 6 & & 6 & & 6 & & $\dot{b}$ & & 6 & & & \\
\hline Sequoia langsdorfii & $26^{\star}$ & & & & $26^{*}$ & & & & & & & & & & & & & \\
\hline Sorbus herzogenrathensis & $7 *$ & & & & $7^{*}$ & & & & & & & & & & & & & \\
\hline Symplocos germanica & $11^{*}$ & & & & $11^{*}$ & & & & & & & & & & & & & \\
\hline
\end{tabular}


Sample 14402 (continued)

\begin{tabular}{|c|c|c|c|c|c|c|c|c|c|c|c|c|c|c|c|c|c|c|c|}
\hline \multirow[t]{2}{*}{ Species } & & & \multicolumn{17}{|c|}{ Vegetational units } \\
\hline & & & 1 & & 2 & & 3 & & 4 & & 5 & & 6 & & 7 & & 8 & & 9 \\
\hline Symplocos gothanii & $\underline{13}^{*}$ & & & & & $\underline{13}^{*}$ & & & & & & & & & & & & & \\
\hline Symplocos lignitarum & $\underline{7}^{*}$ & & & & & $\overline{7}$ & & & & $\underline{7}^{*}$ & & & & & & & & & \\
\hline Symplocos solzhausenensis & $\underline{18} *$ & & & & & $\underline{18}^{*}$ & & & & & & & & & & & & & \\
\hline Umbelliferopsis molassicus & $\overline{1}^{\star}$ & & & $1^{*}$ & & & & & & & & & & & & & & & \\
\hline Viscum sp. & $1^{*}$ & & & & & $1^{*}$ & & & & & & & & & & & & & \\
\hline Vitis sp. & 1 & & & & & 1 & & & & 1 & & & & & & & & & \\
\hline Ziziphus striata & $1^{*}$ & & & & & $1^{*}$ & & & & & & & & & & & & & \\
\hline$?$ & 3 & & & & & & & & & & & & & & & & & & \\
\hline$\Sigma \operatorname{taxa}$ & 26 & - & & 2 & $8 \%$ & 22 & $85 \%$ & 1 & & 5 & $19 \%$ & 2 & $8 \%$ & 1 & & 1 & & 1 & $4 \%$ \\
\hline $\boldsymbol{\Sigma}$ characteristic taxa & 23 & - & & 2 & $9 \%$ & 16 & $70 \%$ & - & & 3 & $13 \%$ & 1 & $4 \%$ & - & & - & & 1 & $4 \%$ \\
\hline$\Sigma$ fruits and seeds & 564 & - & & 5 & & 545 & & 6 & & 16 & & 16 & & 6 & & 6 & & 3 & \\
\hline$\Sigma$ char fruits and seeds & 554 & - & & 5 & $1 \%$ & 527 & $94 \%$ & - & & 9 & $2 \%$ & 10 & $2 \%$ & - & & - & & 3 & $1 \%$ \\
\hline Vegetation figures & & & - & & 18 & & 249 & & - & & 34 & & 14 & & - & & - & & 9 \\
\hline$\Sigma$ palaeotropic taxa & 13 & - & & 1 & $4 \%$ & 11 & $42 \%$ & - & & 2 & $8 \%$ & 1 & $4 \%$ & - & & - & & - & \\
\hline$\Sigma$ pal. char. taxa & 13 & - & & 1 & $4 \%$ & 9 & $39 \%$ & - & & 2 & $9 \%$ & 1 & $4 \%$ & - & & - & & - & \\
\hline$\Sigma$ pal. char. frts and seeds & 436 & - & & 4 & $1 \%$ & 418 & $74 \%$ & - & & 8 & $1 \%$ & 10 & $2 \%$ & - & & - & & - & \\
\hline Palaeotropic figures & & & - & & 9 & & 155 & & - & & 18 & & 10 & & - & & - & & - \\
\hline Arctotertiary figures & & & - & & 9 & & 94 & & - & & 16 & & 4 & & - & & - & & 9 \\
\hline
\end{tabular}

Sample 14403

\begin{tabular}{|c|c|c|c|c|c|c|c|c|c|c|c|c|c|c|c|c|c|c|c|}
\hline \multirow[t]{2}{*}{ Species } & & & \multicolumn{17}{|c|}{ Vegetational units } \\
\hline & & & 1 & & 2 & & 3 & & 4 & & 5 & & 6 & & 7 & & 8 & & 9 \\
\hline Corylopsis urselensis & $2 *$ & & & & & 2 & & & & & & & & & & & & $2 *$ & \\
\hline Distylium uralense & $2^{*}$ & & & & & $2^{\star}$ & & & & & & & & & & & & & \\
\hline Epacridicarpum mudense & $\underline{20} \underline{-}^{*}$ & & & & & 20 & & & & & & & & & & & & $\underline{20 *}$ & \\
\hline Eurya stigmosa & $\overline{1} *$ & & & & & $\mathrm{I}^{\star}$ & & & & & & & & & & & & & \\
\hline Myrica boveyana & $2 \overline{6}^{*}$ & & & & & $2 \overline{6}$ & & & & & & & & & & & & $\underline{26 *}$ & \\
\hline Myrica ceriferiformis & $\overline{2}$ & & & & & $\overline{2}^{\star}$ & & & & & & & & & & & & & \\
\hline Myrica suppanii & $\underline{58 *}$ & & & & & $\underline{58}$ & & & & & & & & & & & & $\underline{58^{*}}$ & \\
\hline Sequoia langsdorfii & $\overline{1}^{*}$ & & & & & $\overline{1}^{*}$ & & & & & & & & & & & & & \\
\hline$?$ & 1 & & & & & & & & & & & & & & & & & & \\
\hline$?$ & 2 & & & & & & & & & & & & & & & & & & \\
\hline$\Sigma$ taxa & 10 & - & & - & & 8 & $80 \%$ & - & & - & & - & & - & & - & & 4 & $40 \%$ \\
\hline$\Sigma$ characteristic taxa & 8 & - & & - & & 4 & $50 \%$ & - & & - & & - & & - & & - & & 4 & $50 \%$ \\
\hline$\Sigma$ fruits and seeds & 115 & - & & - & & 112 & & - & & - & & - & & - & & - & & 106 & \\
\hline$\Sigma$ char. fruits and seeds & 112 & - & & - & & 6 & $5 \%$ & - & & - & & - & & - & & - & & 106 & $95 \%$ \\
\hline Vegetation figures & & & - & & - & & 135 & & - & & - & & - & & - & & - & & 185 \\
\hline$\Sigma$ palaeotropic taxa & 4 & - & & - & & 4 & $40 \%$ & - & & - & & - & & - & & - & & 3 & $30 \%$ \\
\hline$\Sigma$ pal. char. taxa & 4 & - & & - & & 1 & $13 \%$ & - & & - & & - & & - & & - & & 3 & $38 \%$ \\
\hline$\Sigma$ pal. char. frts and seeds & 105 & - & & - & & 1 & $1 \%$ & - & & - & & - & & - & & - & & 104 & $93 \%$ \\
\hline Palaeotropic figures & & & - & & - & & 54 & & - & & - & & - & & - & & - & & 161 \\
\hline Arctotertiary figures & & & - & & - & & 81 & & - & & - & & - & & - & & - & & 24 \\
\hline
\end{tabular}

Sample 8295

\begin{tabular}{|c|c|c|c|c|c|c|c|c|c|c|c|}
\hline \multirow[t]{2}{*}{ Species } & & \multicolumn{10}{|c|}{ Vegetational units } \\
\hline & & 1 & 2 & 3 & 4 & 5 & 6 & 7 & 8 & & 9 \\
\hline Acanthopanax solutus & $\underline{1}^{*}$ & & & & & & $\underline{1}$ & & & & \\
\hline Actinidia faveolata & $\overline{1}$ & & & & $1^{*}$ & & & & & & \\
\hline$A \ln u s$ sp. & $6^{*}$ & & & $6^{*}$ & & & & & & & \\
\hline Ampelopsis malvaeformis & $\underline{1}$ & & & & & $\underline{1}^{*}$ & & & & & \\
\hline Arctostaphyloides menzelii & $\underline{4}^{*}$ & & & 4 & & & & & & $\underline{4}^{*}$ & \\
\hline Brasenia victoriae & $20^{*} 20^{*}$ & & & & & & & & & & \\
\hline Caldesia cylindrica & $\underline{3}^{*}$ & & & & & & & & & & \\
\hline
\end{tabular}


Sample 8295 (continued)

\begin{tabular}{|c|c|c|c|c|c|c|c|c|c|c|c|c|c|c|}
\hline \multirow[t]{2}{*}{ Species } & & \multicolumn{13}{|c|}{ Vegetational units } \\
\hline & & 1 & 2 & 3 & & 4 & 5 & 6 & & 7 & & 8 & & 4 \\
\hline Carex acutiformis & $11^{*}$ & $11^{*}$ & & & & & & & & & & & & \\
\hline Carex flagellaia & $2^{\star}$ & $2^{\star}$ & & & & & & & & & & & & \\
\hline Carex hostiana & $7^{*}$ & $7^{\star}$ & & & & & & & & & & & & \\
\hline Carex sp. div. & 3 & & & & & & & & & & & & & \\
\hline Carpinus betulus & $5 *$ & & & & & & $5^{*}$ & & & & & & & \\
\hline Caricoidea jugata & $16^{*}$ & $16^{*}$ & & & & & & & & & & & & \\
\hline Carya ventricosa & $1^{*}$ & & & $1^{*}$ & & & & & & & & & & \\
\hline Carya sp vel Juglans sp. & 1 & & & & & & & & & & & & & \\
\hline Ceratophyllum demersum & $3^{*} 3^{\star}$ & & & & & & & & & & & & & \\
\hline Chenopodium album & $7^{\star}$ & $7^{*}$ & & & & & & & & & & & & \\
\hline Cladiocarya trebovensis & $3^{*}$ & $3^{\star}$ & & & & & & & & & & & & \\
\hline Cladium reidiorum & $2^{\star}$ & $\underline{2}^{\star}$ & & & & & & & & & & & & \\
\hline Corylus avellana & $1 *$ & & & & $1^{\star}$ & & & & & & & & & \\
\hline Cyclocarya nucifera & $2^{*}$ & & & & & & & $2^{*}$ & & & & & & \\
\hline Distylium uralense & $5^{*}$ & & & $5 *$ & & & & & & & & & & \\
\hline Dulichium spathaceum & $\mathrm{I}^{*}$ & $1^{*}$ & & & & & & & & & & & & \\
\hline Eomastixia persicoides & $32^{\star}$ & & & $32 *$ & & & & & & & & & & \\
\hline Epacridicarpum mudense & $\overline{2} *$ & & & 2 & & & & & & & & & $2^{*}$ & \\
\hline Eurya stigmosa & $14 \overline{7}^{\star}$ & & & $147^{*}$ & & & & & & & & & & \\
\hline Fagus decurrens & $17^{\star}$ & & & & & & & $17^{\star}$ & & & & & & \\
\hline Glyptostrobus europaeus & $11^{*}$ & & & $11^{*}$ & & & & & & & & & & \\
\hline Halesia crassa & $156^{*}$ & & & & & & & $156^{\star}$ & & & & & & \\
\hline Homalanthus costatus & $26^{\star}$ & & & $26^{*}$ & & & & & & & & & & \\
\hline Hypericum holyi & 2 & 2 & & 2 & & & & & & & & & & \\
\hline Ilex saxonica & 1 & & & 1 & & & & 1 & 1 & & & & & \\
\hline Liquidambar magniloculata & 4 & & & & & & 4 & 4 & & & & & & \\
\hline Liriodendron geminatum & $22^{\star}$ & & & 22 & & & $22^{*}$ & & & & & & & \\
\hline Magnolia burseracea & 40 & & & $40^{\star}$ & & & & & & & & & & \\
\hline Magnolia lignita & $10^{*}$ & & & $\underline{10}^{*}$ & & & & & & & & & & \\
\hline Magnolia tusatica & $\underline{11}^{*}$ & & & $1^{*}$ & & & & & & & & & & \\
\hline Mastixia thomsonii & $\underline{127}^{*}$ & & & $\underline{127}$ & & & $127^{\star}$ & & & & & & & \\
\hline Menyanthes carpathica & $\overline{3^{*}}$ & $3^{*}$ & & & & & & & & & & & & \\
\hline Myrica minima & $7500^{*}$ & & & $7500^{*}$ & & & & & & & & & & \\
\hline Myrica supponii & $2^{*}$ & & & 2 & & & & & & & & & $\underline{2}^{*}$ & \\
\hline Nyssa disseminata & 7* & & & $3^{*}$ & & & & & & & & & & \\
\hline Nyssa ornithobroma & $5^{*}$ & & & $5^{*}$ & & & & & & & & & & \\
\hline Ostrya scholzii & $27^{\star}$ & & & & & & $27^{\star}$ & & & & & & & \\
\hline Oxydendrum europaeum & 1 & & & & & & & 1 & 1 & & & & & \\
\hline Palliopora symplocoides & 17 & & & & 17 & & $\underline{17}$ & 17 & & & & & & \\
\hline Picea omorikoides & $1^{\star}$ & & & & & & & & $1^{\star}$ & & & & & \\
\hline Pinaceae & 9 & & & 9 & & & & 9 & 9 & & & & 9 & \\
\hline Proserpinaca reticulata & $8^{*}$ & & & $8^{\star}$ & & & & & & & & & & \\
\hline Pseudoeuryale limburgensis & $1 * 1^{*}$ & & & & & & & & & & & & & \\
\hline Pterocarya limburgensis & $5^{\star}$ & & & $5^{*}$ & & & & & & & & & & \\
\hline Punica natans & $1790^{*}$ & & & & & & & $1790^{\star}$ & & & & & & \\
\hline Rehderodendron ehrenbergii & $\underline{7}$ & & & & $\underline{7}$ & & 7 & 7 & & & & & & \\
\hline Rubus laticostatus & $2 \overline{0}$ & & & 20 & $2 \overline{0}$ & & 20 & 20 & 20 & & 20 & & & \\
\hline Sapium germanicum & $33^{\star}$ & & & $33^{*}$ & & & & & & & & & & \\
\hline Scindapsites crassus & $5^{\star}$ & $\underline{5}^{\star}$ & & & & & & & & & & & & \\
\hline Scirpus lacustris & $\overrightarrow{2^{*}}$ & $\overline{2}^{\star}$ & & & & & & & & & & & & \\
\hline Scirpus melanospermus & $1^{*}$ & $1 *$ & & & & & & & & & & & & \\
\hline Sequoia langsdorfii & $3579^{\star}$ & & & $3579^{\star}$ & & & & & & & & & & \\
\hline Sinomenium militzeri & 3 & & & & 3 & & 3 & & & & & & & \\
\hline Sorbus aria & $1^{\star}$ & & & & & & & $1 \star$ & & & & & & \\
\hline Sparganium minimum & $2^{*}$ & $2^{*}$ & & & & & & & & & & & & \\
\hline Sparganium haentzschelii & $10^{*}$ & $10^{*}$ & & & & & & & & & & & & \\
\hline Sphenotheca incurva & 17 & & & & $\underline{17}$ & & $\underline{17}$ & $\underline{17}$ & & & & & & \\
\hline Staphylea bessarabica & 3 & & & & $\overline{3}$ & & $\overline{3}$ & $\overline{3}$ & & & & & & \\
\hline Stellaria media & $1^{*}$ & $1 *$ & & & & & & & & & & & & \\
\hline Stratiotes tuberculatus & $12^{*} 12^{*}$ & & & & & & & & & & & & & \\
\hline Styrax maximus & $5^{*}$ & & & & & & & $\underline{5}^{*}$ & & & & & & \\
\hline Symplocos germanica & $\underline{2}^{*}$ & & & $2^{*}$ & & & & & & & & & & \\
\hline Symplocos gothanii & $\overrightarrow{55}^{*}$ & & & $55^{\star}$ & & & & & & & & & & \\
\hline Symplocos lignitarum & $41 \overline{59}^{\star}$ & & & 4159 & & & $4159^{\star}$ & & & & & & & \\
\hline Symplocos minutula & $\overline{20^{*}}$ & & & $\underline{20}$ & & & & & & & & & & \\
\hline Symplocos pseudogregaria & $\underline{\underline{2}}^{*}$ & & & $\overline{\underline{2}}$ & & & $\underline{2}^{*}$ & & & & & & & \\
\hline Symplocos salzhausenensis & $\underline{10 \overline{6}^{*}}$ & & & $\underline{106^{\star}}$ & & & & & & & & & & \\
\hline Symplocos schereri & 26 & & & & & & $\underline{26}$ & $\underline{26}$ & & & & & & \\
\hline Toxodium dubium & $97 *$ & & & $97^{\star}$ & & & & & & & & & & \\
\hline
\end{tabular}


Sample 8296 (continued)

\begin{tabular}{|c|c|c|c|c|c|c|c|c|c|c|c|c|c|c|c|c|c|c|c|}
\hline \multirow[t]{2}{*}{ Species } & & & \multicolumn{17}{|c|}{ Vegetational units } \\
\hline & & & 1 & & 2 & & 3 & & 4 & & 5 & & 6 & & 7 & & 8 & & 9 \\
\hline Tectocarya rhenana & 1 & & & & & 1 & & & & 1 & & & & & & & & & \\
\hline Tetrastigma lobata & $\underline{65}{ }^{\star}$ & & & & & $\underline{65}$ & & & & $65^{*}$ & & & & & & & & & \\
\hline Toddalia naviculaeformis & $\overline{24} *$ & & & & & $\overline{24}^{*}$ & & & & & & & & & & & & & \\
\hline Toddalia rhenana & $\underline{14}^{*}$ & & & & & $\underline{14}^{\star}$ & & & & & & & & & & & & & \\
\hline Trapa heerii & $\overline{1}^{*}$ & $1^{*}$ & & & & & & & & & & & & & & & & & \\
\hline Vitis lusatica & $11^{*}$ & & & & & 11 & & & & $11^{\star}$ & & & & & & & & & \\
\hline Vitis parasyluestris & 8 & & & & & 8 & & & & 8 & & & & & & & & & \\
\hline Vitis teutonica & $29^{*}$ & & & & & 29 & & & & $29^{*}$ & & & & & & & & & \\
\hline Zanthoxylum ailanthiforme & $13^{*}$ & & & & & & & & & $13^{*}$ & & & & & & & & & \\
\hline$?$ & 120 & & & & & & & & & & & & & & & & & & \\
\hline$?$ & 6 & & & & & & & & & & & & & & & & & & \\
\hline$\Sigma$ taxa & 87 & 5 & $6 \%$ & 17 & $20 \%$ & 40 & $46 \%$ & 8 & $9 \%$ & 20 & $23 \%$ & 17 & $20 \%$ & 5 & $6 \%$ & 1 & 4 & $5 \%$ & \\
\hline$\Sigma$ characteristic taxa & 70 & 5 & $7 \%$ & 16 & $23 \%$ & 24 & $34 \%$ & 2 & $3 \%$ & 12 & $17 \%$ & 7 & $10 \%$ & 1 & $1 \%$ & - & 3 & $4 \%$ & \\
\hline$\Sigma$ fruits and seeds & 18533 & 37 & & 78 & & 16193 & & 69 & & 4567 & & 2077 & & 32 & & 20 & 17 & & \\
\hline$\Sigma$ char. fruits and seeds & 18306 & 37 & $\mathbf{x}$ & 76 & $\mathbf{x}$ & 11731 & $64 \%$ & 2 & $\mathbf{x}$ & 4483 & $24 \%$ & 1972 & $11 \%$ & 1 & $\mathbf{x}$ & - & 8 & $\mathbf{x}$ & \\
\hline Vegetation figures & & & 13 & & 43 & & 144 & & 12 & & 64 & & 41 & & 7 & & - & & 9 \\
\hline$\Sigma$ palaeotropic taxa & 38 & - & & 5 & $6 \%$ & 21 & $24 \%$ & 4 & $\mathbf{5} \%$ & 12 & $14 \%$ & 10 & $11 \%$ & 1 & $1 \%$ & - & & 3 & $3 \%$ \\
\hline$\Sigma$ pal. char. taxa & 29 & - & & 5 & $7 \%$ & 12 & $17 \%$ & - & & 6 & $9 \%$ & 3 & $4 \%$ & - & & - & & 3 & $4 \%$ \\
\hline$\Sigma$ pal. char. frts and seeds & 6732 & - & & 29 & $x$ & 494 & $3 \%$ & - & & 4367 & $24 \%$ & 1796 & $10 \%$ & - & & - & & 8 & $x$ \\
\hline Palaeotropic figures & & & $-\cdot$ & & 13 & & 44 & & 5 & & 47 & & 25 & & 1 & & - & & 7 \\
\hline Arctotertiary figures & & & 13 & & 30 & & 100 & & 7 & & 17 & & 16 & & 6 & & - & & 2 \\
\hline
\end{tabular}

Sample 8699

Species

Vegetational units

1

$2 \quad 3$

\begin{tabular}{l}
\hline \\
Actinidia faveolata \\
Alnus sp. \\
Asimina brownii \\
Crataegus acuticarpa \\
Eomastixia persicoides \\
Eucommia europaea \\
Eurya stigmosa \\
Fagus decurrens \\
Halesia crassa \\
Homalanthus costatus \\
Liquidambar magniloculata \\
Mastixia thomsonii \\
Myrica ceriferiformis \\
Myrica minima \\
Nyssa disseminata \\
Nyssa ornithobroma \\
Ostrya scholzii \\
Palliopora symplocoides \\
Picea omorikoides \\
Pinaceae \\
Polyspora lignitica \\
Potamogeton sp. \\
Pterocarya limburgensis \\
Punica natans \\
Rubus laticostatus \\
Sapium germanicum \\
Sequoia langsdorfi \\
Sparganium haentzschelii \\
Stewartia beckeriana \\
Symplocos germanica \\
Symplocos gothanii \\
Symplocos lignitarum \\
Symplocos salahausenensis \\
Symplocos schereri \\
Taxodium dubium \\
Tectocarya rhenana \\
\end{tabular}

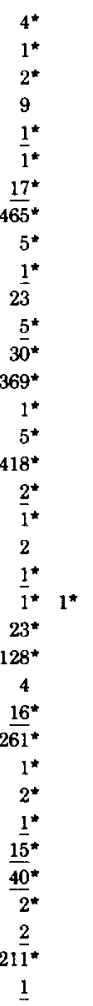

3

4

45

$5 \quad 6$

6

7

$8 \quad 9$

1*

$$
\begin{gathered}
1^{*} \\
1^{*} \\
17^{*} \\
\\
1^{*} \\
5 \\
30^{\star} \\
369^{*} \\
1^{*} \\
5^{*}
\end{gathered}
$$

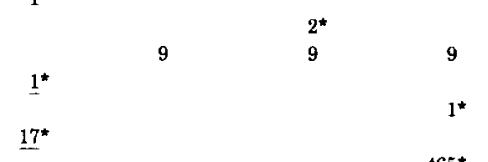

$5^{4}+465^{*}$

$\begin{array}{ccc}\underline{1}^{\star} & 23 & 23 \\ 30^{\star} & \underline{5}^{*} & \end{array}$

2

4

$\frac{16^{*}}{261^{*}}$

$261^{*}$

$\frac{\frac{1}{5}^{*}}{\frac{40}{2}}$

$211^{*}$

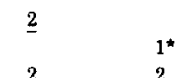

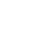

$128^{*}$

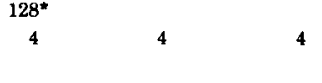


Sample 8699 (continued)

\begin{tabular}{|c|c|c|c|c|c|c|c|c|c|c|c|c|c|c|c|c|c|c|c|}
\hline \multirow[t]{2}{*}{ Species } & & & \multicolumn{17}{|c|}{ Vegetational units } \\
\hline & & & 1 & & 2 & & 3 & & 4 & & 5 & & i & & 7 & & 8 & & 4 \\
\hline Vitis lusatica & $8^{*}$ & & & & & 8 & & & & $8^{*}$ & & & & & & & & & \\
\hline Vitis teutonica & $4^{*}$ & & & & & 4 & & & & $4^{*}$ & & & & & & & & & \\
\hline$?$ & 30 & & & & & & & & & & & & & & & & & & \\
\hline$?$ & 17 & & & & & & & & & & & & & & & & & & \\
\hline$?$ & 2 & & & & & & & & & & & & & & & & & & \\
\hline$\sum \operatorname{taxa}$ & 41 & 1 & $2 \%$ & 1 & $2 \%$ & 21 & $51 \%$ & 4 & $10 \%$ & 13 & $32 \%$ & 11 & $27 \%$ & 8 & $7 \%$ & 1 & & ? & \\
\hline$\Sigma$ characteristic taxa & 31 & 1 & $3 \%$ & 1 & $3 \%$ & 13 & $42 \%$ & 1 & $3 \%$ & 7 & $23 \%$ & 5 & $16_{\%}^{\circ}$ & 1 & $3^{n} \%$ & & & & \\
\hline$\Sigma$ fruits and seeds & 2132 & 1 & & 1 & & 978 & & 19 & & 519 & & 643 & & 7 & & 4 & & 2 & \\
\hline$\Sigma$ char fruits and seeds & 2040 & 1 & & 1 & & 944 & $47 \%$ & 4 & & 478 & $23 \%$ & 601 & $29 \%$ & 1 & & & & & \\
\hline Vegetation figures & & & 5 & & 5 & & 140 & & 13 & & 78 & & 72 & & 10 & & & & \\
\hline$\Sigma$ palaeotropic taxa & 13 & $\ldots$ & & - & & 10 & $24 \%$ & 1 & $2 \%$ & 6 & $1.5 \%$ & 2 & $5 \%$ & & & & & & \\
\hline$\Sigma$ pal. char. frts and seeds & 99 & - & & & & 53 & $3 \%$ & - & & 46 & $2^{\circ}$ & & & & & & & & \\
\hline Palaeotropic figures & & & & & & & 50 & & 2 & & 27 & & 5 & & & & & & \\
\hline Arctotertiary figures & & & 5 & & 5 & & 90 & & 11 & & 51 & & 67 & & 10 & & & & \\
\hline
\end{tabular}

Sample 8700

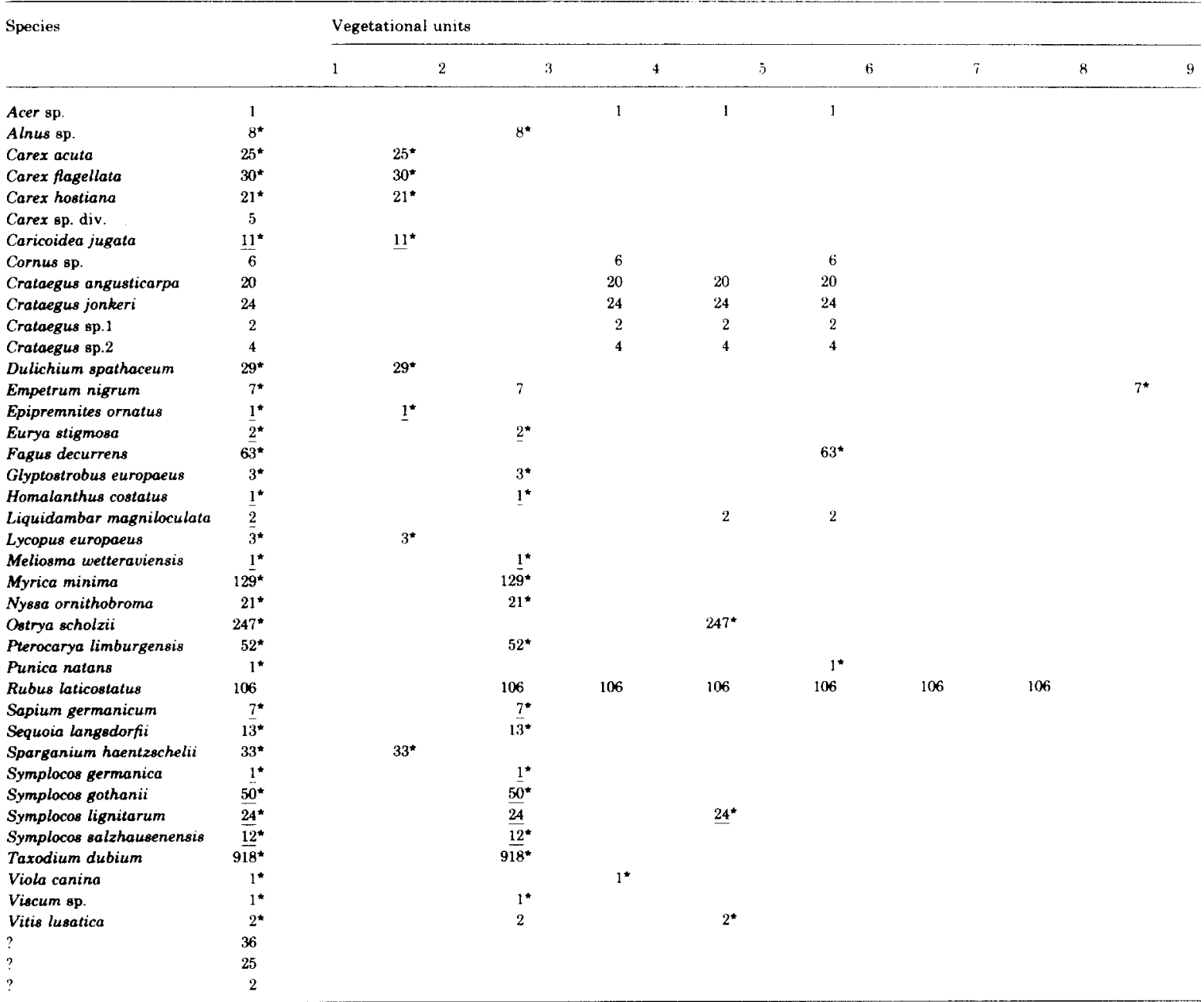


Sample 8700 (continued)

\begin{tabular}{|c|c|c|c|c|c|c|c|c|c|c|c|c|c|c|c|c|c|c|c|}
\hline \multirow[t]{2}{*}{ Species } & & & \multicolumn{17}{|c|}{ Vegetational units } \\
\hline & & & 1 & & 2 & & 3 & & 4 & & 5 & & 6 & & 7 & & 8 & & 9 \\
\hline$\sum$ taxa & 42 & - & & 8 & $19 \%$ & 19 & $45 \%$ & 8 & $19 \%$ & 10 & $24 \%$ & 10 & $24 \%$ & 1 & & 1 & & 1 & $2 \%$ \\
\hline$\Sigma$ characteristic taxa & 30 & - & & 8 & $27 \%$ & 15 & $50 \%$ & 1 & $3 \%$ & 3 & $10 \%$ & 2 & $7 \%$ & - & & - & & 1 & $3 \%$ \\
\hline$\Sigma$ fruits and seeds & 1950 & - & & 153 & & 1358 & & 164 & & 432 & & 229 & & 106 & & 106 & & 7 & \\
\hline$\Sigma$ char. fruits and seeds & 1716 & - & & 153 & $9 \%$ & 1218 & $71 \%$ & 1 & $x$ & 273 & $16 \%$ & 64 & $4 \%$ & - & & - & & 7 & $\mathbf{x}$ \\
\hline Vegetation figures & & & - & & 55 & & 166 & & 22 & & 50 & & 35 & & - & & - & & $\mathbf{5}$ \\
\hline$\Sigma$ palaeotropic taxa & 11 & - & & 2 & $5 \%$ & 8 & $19 \%$ & - & & 1 & $2 \%$ & 1 & $2 \%$ & - & & - & & - & \\
\hline I pal. char. taxa & 11 & - & & 2 & $7 \%$ & 7 & $23 \%$ & - & & 1 & $3 \%$ & 1 & $3 \%$ & - & & - & & - & \\
\hline$\Sigma$ pal. char. frts and seeds & 111 & - & & 12 & $1 \%$ & 73 & $4 \%$ & - & & 24 & $1 \%$ & 1 & $\mathbf{x}$ & - & & - & & - & \\
\hline Palaeotropic figures & & & - & & 13 & & 46 & & - & & 6 & & 5 & & - & & - & & - \\
\hline Arctotertiary figures & & & - & & 42 & & 120 & & 22 & & 44 & & 30 & & - & & - & & 5 \\
\hline
\end{tabular}

Sample 13349

\begin{tabular}{|c|c|c|c|c|c|c|c|c|c|c|c|c|c|c|c|c|c|c|c|}
\hline \multirow[t]{2}{*}{ Species } & & & \multicolumn{17}{|c|}{ Vegetational units } \\
\hline & & & 1 & & 2 & & 3 & & 4 & & 5 & & 6 & & 7 & & 8 & & 9 \\
\hline Alnus sp. & $49^{\star}$ & & & & & $49^{*}$ & & & & & & & & & & & & & \\
\hline Caldesia cylindrica & $13^{*}$ & & & $13^{*}$ & & & & & & & & & & & & & & & \\
\hline Ceratophyllum submersum & $70^{*}$ & $70^{*}$ & & & & & & & & & & & & & & & & & \\
\hline Decodon globosus & $1^{*}$ & & & $1^{*}$ & & & & & & & & & & & & & & & \\
\hline Fagus decurrens & $1^{\star}$ & & & & & & & & & & & $1^{*}$ & & & & & & & \\
\hline Glyptostrobus europaeus & $17^{\star}$ & & & & & $17^{\star}$ & & & & & & & & & & & & & \\
\hline Homalanthus costatus & $1^{*}$ & & & & & $\underline{1}$ & & & & & & & & & & & & & \\
\hline Liriodendron geminatum & $12^{*}$ & & & & & $12^{*}$ & & & & $12^{\star}$ & & & & & & & & & \\
\hline Magnolia burseracea & $3^{\star}$ & & & & & $3^{*}$ & & & & & & & & & & & & & \\
\hline Magnolia lusatica & $\overline{7}^{*}$ & & & & & $7 *$ & & & & & & & & & & & & & \\
\hline Nyssa disseminata & $\overline{2} \star$ & & & & & $\overline{2}$ & & & & & & & & & & & & & \\
\hline Nyssa ornithobroma & $2^{\star}$ & & & & & $2^{\star}$ & & & & & & & & & & & & & \\
\hline Potamogeton sp. & $4^{*}$ & $4^{*}$ & & & & & & & & & & & & & & & & & \\
\hline Pterocarya limburgensis & $35^{*}$ & & & & & $35^{*}$ & & & & & & & & & & & & & \\
\hline Rubus laticostatus & 1 & & & & & 1 & & 1 & & 1 & & 1 & & 1 & & 1 & & & \\
\hline Taxodium dubium & $688^{*}$ & & & & & $688^{\star}$ & & & & & & & & & & & & & \\
\hline Trapa heerii & $5^{*}$ & $5^{*}$ & & & & & & & & & & & & & & & & & \\
\hline Viscum sp. & $147^{\star}$ & & & & & $147^{\star}$ & & & & & & & & & & & & & \\
\hline$?$ & 34 & & & & & & & & & & & & & & & & & & \\
\hline$?$ & 3 & & & & & & & & & & & & & & & & & & \\
\hline$?$ & 1 & & & & & & & & & & & & & & & & & & \\
\hline$?$ & 1 & & & & & & & & & & & & & & & & & & \\
\hline$\Sigma \operatorname{taxa}$ & 22 & 3 & $14 \%$ & 2 & $9 \%$ & 12 & $55 \%$ & 1 & & 2 & $9 \%$ & 2 & $9 \%$ & 1 & & 1 & & - & \\
\hline$\Sigma$ characteristic taxa & 17 & 3 & $18 \%$ & 2 & $12 \%$ & 10 & $59 \%$ & - & & 1 & $6 \%$ & 1 & $6 \%$ & - & & - & & - & \\
\hline$\Sigma$ fruits and seeds & 1097 & 79 & & 14 & & 964 & & 1 & & 13 & & 2 & & 1 & & 1 & & - & \\
\hline$\Sigma$ char. fruits and seeds & 1057 & 79 & $8 \%$ & 14 & $1 \%$ & 951 & $90 \%$ & - & & 12 & $1 \%$ & 1 & & - & & - & & - & \\
\hline Vegetation figures & & & 40 & & 22 & & 204 & & - & & 16 & & 15 & & - & & - & & - \\
\hline$\Sigma$ palaeotropic taxa & 4 & - & & 1 & $5 \%$ & 3 & $14 \%$ & - & & - & & - & & - & & - & & - & \\
\hline$\Sigma$ pal. char. taxa & 4 & - & & 1 & $6 \%$ & 3 & $18 \%$ & - & & - & & - & & - & & - & & - & \\
\hline$\Sigma$ pal. char. frts and seeds & 24 & - & & 13 & $1 \%$ & 11 & $1 \%$ & - & & - & & - & & - & & - & & - & \\
\hline Palaeotropic figures & & & - & & 12 & & 43 & & - & & _- & & - & & - & & - & & - \\
\hline Arctotertiary figures & & & 40 & & 10 & & 161 & & - & & 16 & & 15 & & - & & - & & - \\
\hline
\end{tabular}

Sample 14139

\begin{tabular}{|c|c|c|c|c|c|c|c|c|c|c|}
\hline \multirow[t]{2}{*}{ Species } & & \multicolumn{9}{|c|}{ Vegetational units } \\
\hline & & 1 & 2 & 3 & 4 & 5 & 6 & 7 & 8 & 9 \\
\hline Acanthopanax solutus & $\underline{1} \underline{1}^{*}$ & & & & & & $1 *$ & & & \\
\hline Asimina brownii & $\overline{2}^{\star}$ & & & & & $2 *$ & & & & \\
\hline Eomastixia persicoides & $\underline{2}^{\star}$ & & & & & & & & & \\
\hline Eurya stigmasa & $\underline{\overline{1}}^{*}$ & & & & & & & & & \\
\hline
\end{tabular}


Sample 14139 (continued)

\begin{tabular}{|c|c|c|c|c|c|c|c|c|c|c|c|c|c|c|c|c|c|c|c|}
\hline \multirow[t]{2}{*}{ Species } & & & \multicolumn{17}{|c|}{ Vegetational units } \\
\hline & & & 1 & & 2 & & 3 & & 4 & & 5 & & 6 & & $i$ & & 8 & & 9 \\
\hline Glyptostrobus europaeus & $6^{*}$ & & & & & $6^{*}$ & & & & & & & & & & & & & \\
\hline Homalanthus costatus & $28^{*}$ & & & & & $28^{\star}$ & & & & & & & & & & & & & \\
\hline Liquidambar magniloculata & 1 & & & & & & & & & 1 & & 1 & & & & & & & \\
\hline Magnolia burseracea & $\underline{1}^{*}$ & & & & & $1^{*}$ & & & & & & & & & & & & & \\
\hline Magnolia lusatica & $8^{*}$ & & & & & $\underline{8}^{\star}$ & & & & & & & & & & & & & \\
\hline Myrica minima & $\overline{3}$ & & & & & $\overline{3}^{*}$ & & & & & & & & & & & & & \\
\hline Myrica suppanii & $1^{*}$ & & & & & 1 & & & & & & & & & & & & $1^{*}$ & \\
\hline Nyssa disseminata & $\overline{3}^{\star}$ & & & & & $3^{*}$ & & & & & & & & & & & & & \\
\hline Phellodendron lusaticum & $2^{\star}$ & & & & & & & & & & & $2^{*}$ & & & & & & & \\
\hline Picea omorikoides & $1^{*}$ & & & & & & & & & & & & & $1^{\star}$ & & & & & \\
\hline Pinaceae & 17 & & & & & 17 & & & & & & 17 & & 17 & & & & 17 & \\
\hline Pinus leitzii & 12 & & & & & 12 & & & & & & & & 12 & & & & 12 & \\
\hline Rubus laticostatus & 2 & & & & & 2 & & 2 & & 2 & & 2 & & 2 & & 2 & & & \\
\hline Sequoia langsdorfii & $169^{*}$ & & & & & $169^{*}$ & & & & & & & & & & & & & \\
\hline Sparganium haentzschelii & $1^{*}$ & & & $1^{\star}$ & & & & & & & & & & & & & & & \\
\hline Sphenotheca incurva & 3 & & & & & & & 3 & & 3 & & $\underline{3}$ & & & & & & & \\
\hline Symplocos gothanii & $27^{\star}$ & & & & & $\underline{27^{\star}}$ & & & & & & & & & & & & & \\
\hline Symplocos lignitarum & $\overline{4}^{*}$ & & & & & $\overline{4}$ & & & & $4^{*}$ & & & & & & & & & \\
\hline Symplocos schereri & $\underline{6}$ & & & & & & & & & $\underline{6}$ & & $\underline{6}$ & & & & & & & \\
\hline Tetrastigma lobata & $1 \overline{2}^{\star}$ & & & & & 12 & & & & $\overline{1}^{*}$ & & & & & & & & & \\
\hline$?$ & 1 & & & & & & & & & & & & & & & & & & \\
\hline$\sum \tan a$ & 25 & - & & 1 & $4 \%$ & 16 & $64 \%$ & 2 & & 7 & $28 \%$ & 7 & $28 \%$ & 4 & $16 \%$ & 1 & & 3 & $12 \%$ \\
\hline$\Sigma$ characteristic taxa & 18 & & & 1 & $6 \%$ & 10 & $56 \%$ & & & 3 & $17 \%$ & 2 & $11 \%$ & 1 & $6 \%$ & & & 1 & $6 \%$ \\
\hline$\Sigma$ fruits and seeds & 325 & $\therefore$ & & 1 & & 310 & & 5 & & 30 & & 32 & & 32 & & 2 & & 30 & \\
\hline$\Sigma$ char. fruits and seeds & 283 & - & & 1 & & 262 & $93 \%$ & - & & 18 & $6 \%$ & 3 & 1 & 1 & & & & 1 & \\
\hline Vegetation figures & & & -. & & 10 & & 213 & & & & 51 & & 40 & & 22 & & & & 18 \\
\hline$\sum$ palaeotropic taxa & 12 & - & & & & 9 & $36 \%$ & 1 & & 4 & $16 \%$ & 3 & $12 \%$ & & & - & & 1 & $4 \%$ \\
\hline$\Sigma$ pal. char. taxa & 10 & & & & & 6 & $33 \%$ & & & 2 & $11 \%$ & 1 & $6 \%$ & & & & & 1 & $6 \%$ \\
\hline$\Sigma$ pal. char. frts and seeds & 99 & -. & & & & 81 & $29 \%$ & -. & & 16 & $6 \%$ & 1 & & & & & & 1 & \\
\hline Palaeotropic figures & & & - & & & & 98 & & & & 33 & & 18 & & & & $\cdots$ & & 10 \\
\hline Arctotertiary figures & & & $\ldots$ & & 10 & & 115 & & & & 18 & & 22 & & 22 & & .. & & 8 \\
\hline
\end{tabular}

\section{Sample 14140}

\begin{tabular}{|c|c|c|c|c|c|c|c|c|c|c|c|c|c|c|c|c|}
\hline \multirow[t]{2}{*}{ Species } & & \multicolumn{15}{|c|}{ Vegetational units } \\
\hline & & 1 & & 2 & 3 & & 4 & 5 & & 6 & & 7 & & 8 & & 9 \\
\hline Carex acutiformis & 9* & & $9^{*}$ & & & & & & & & & & & & & \\
\hline Carex hostiana & $4^{\star}$ & & $4^{*}$ & & & & & & & & & & & & & \\
\hline Caricoidea jugata & $\underline{24}^{*}$ & & $24^{*}$ & & & & & & & & & & & & & \\
\hline Eomastixia persicoides & $8^{*}$ & & & & $\underline{8}^{*}$ & & & & & & & & & & & \\
\hline Eurya stigmosa & $17^{*}$ & & & & $1 \overline{7}^{\star}$ & & & & & & & & & & & \\
\hline Glyptostrobus europaeus & $185^{*}$ & & & & $185^{*}$ & & & & & & & & & & & \\
\hline Halesia crassa & $1^{*}$ & & & & & & & & $1^{*}$ & & & & & & & \\
\hline Homalanthus costatus & $11^{*}$ & & & & $11^{*}$ & & & & & & & & & & & \\
\hline llex saxonica & $\overline{3}$ & & & & $\overline{3}$ & & & & $\underline{3}$ & & 3 & & & & & \\
\hline Liquidambar magniloculata & $\overline{1}$ & & & & & & & 1 & $\overline{1}$ & & & & & & & \\
\hline Magnolia burseracea & $3^{*}$ & & & & $\underline{3}^{*}$ & & & & & & & & & & & \\
\hline Magnolia lusatica & $\overline{4}^{*}$ & & & & $\overline{4}^{\star}$ & & & & & & & & & & & \\
\hline Mastixia thomsonii & $\dot{\overline{4}}^{*}$ & & & & $\underline{4}$ & & & $4^{*}$ & & & & & & & & \\
\hline Nyssa disseminata & $\overline{3}$ & & & & $\overline{3}^{\star}$ & & & & & & & & & & & \\
\hline Palliopora symplocoides & 31 & & & & & 31 & & 31 & 31 & & & & & & & \\
\hline Picea sp. & $1 *$ & & & & & & & & & & $1^{*}$ & & & & & \\
\hline Pinaceae & 2 & & & & 2 & & & & 2 & & 2 & & & & 2 & \\
\hline Pinus spinosa & 1 & & & & 1 & & & & & & 1 & & & & 1 & \\
\hline Rubus laticostatus & 5 & & & & 5 & 5 & & 5 & 5 & & 5 & & 5 & & & \\
\hline Scindapsites crassus & $1^{*}$ & & $\underline{1}^{*}$ & & & & & & & & & & & & & \\
\hline Sequoia langadorfii & $283^{*}$ & & & & $283^{*}$ & & & & & & & & & & & \\
\hline Sphenotheca incurva & 5 & & & & & $\underline{5}$ & & 5 & $\underline{5}$ & & & & & & & \\
\hline Symplocos germanica & $\underline{44}^{*}$ & & & & $\underline{44^{*}}$ & & & & & & & & & & & \\
\hline Symplocos lignitarum & $954^{*}$ & & & & 954 & & & $954^{*}$ & & & & & & & & \\
\hline Symplocos pseudogregaria & $\underline{162} *$ & & & & $\underline{162}$ & & & $162^{*}$ & & & & & & & & \\
\hline Symplocos schereri & 8 & & & & & & & $\overline{8}$ & $\underline{8}$ & & & & & & & \\
\hline
\end{tabular}


Sample 14140 (continued)

\begin{tabular}{|c|c|c|c|c|c|c|c|c|c|c|c|c|c|c|c|c|c|c|c|}
\hline \multirow[t]{2}{*}{ Species } & & & \multicolumn{17}{|c|}{ Vegetational units } \\
\hline & & & 1 & & 2 & & 3 & & 4 & & 5 & & 6 & & 7 & & 8 & & 9 \\
\hline Tectocarya rhenana & $\underline{5}$ & & & & & $\underline{\mathbf{5}}$ & & & & $\underline{5}$ & & & & & & & & & \\
\hline Tetrastigma lobata & $\underline{46}$ & & & & & $\underline{46}$ & & & & $\underline{46}^{*}$ & & & & & & & & & \\
\hline$?$ & 1 & & & & & & & & & & & & & & & & & & \\
\hline$?$ & 1 & & & & & & & & & & & & & & & & & & \\
\hline$?$ & 1 & & & & & & & & & & & & & & & & & & \\
\hline$?$ & 1 & & & & & & & & & & & & & & & & & & \\
\hline$?$ & 1 & & & & & & & & & & & & & & & & & & \\
\hline$?$ & 1 & & & & & & & & & & & & & & & & & & \\
\hline$\Sigma$ taxa & 34 & - & & 4 & $12 \%$ & 18 & $53 \%$ & 3 & & 10 & $29 \%$ & 8 & $24 \%$ & 5 & $15 \%$ & 1 & & 2 & \\
\hline$\Sigma$ characteristic taxa & 19 & - & & 4 & $21 \%$ & 9 & $47 \%$ & - & & 4 & $21 \%$ & 1 & $5 \%$ & 1 & $5 \%$ & - & & - & \\
\hline$\Sigma$ fruits and seeds & 1832 & - & & 38 & & 1740 & & 41 & & 1221 & & 56 & & 12 & & 5 & & 3 & \\
\hline$\Sigma$ char. fruits and seeds & 1718 & - & & 38 & $2 \%$ & 599 & $35 \%$ & - & & 1166 & $68 \%$ & 1 & $\mathbf{x}$ & 1 & $\mathbf{x}$ & - & & - & \\
\hline Vegetation figures & & & - & & 35 & & 135 & & - & & 118 & & 29 & & 20 & & - & & - \\
\hline I palaeotropic taxa & 17 & - & & 2 & $6 \%$ & 12 & $35 \%$ & 2 & & 8 & $24 \%$ & 4 & $12 \%$ & 1 & $3 \%$ & - & & - & \\
\hline$\Sigma$ pal. char. taxa & 12 & - & & 2 & $11 \%$ & 6 & $32 \%$ & - & & 4 & $21 \%$ & - & & - & & - & & - & \\
\hline$\Sigma$ pal. char. frts and seeds & 1278 & - & & 25 & $1 \%$ & 87 & $5 \%$ & - & & 1166 & $68 \%$ & - & & - & & - & & - & \\
\hline Palaeotropic figures & & & - & & 18 & & 72 & & - & & 113 & & 12 & & 3 & & - & & - \\
\hline Arctotertiary figures & & & - & & 17 & & 63 & & - & & 5 & & 17 & & 17 & & - & & - \\
\hline
\end{tabular}

\section{Sample 14141}

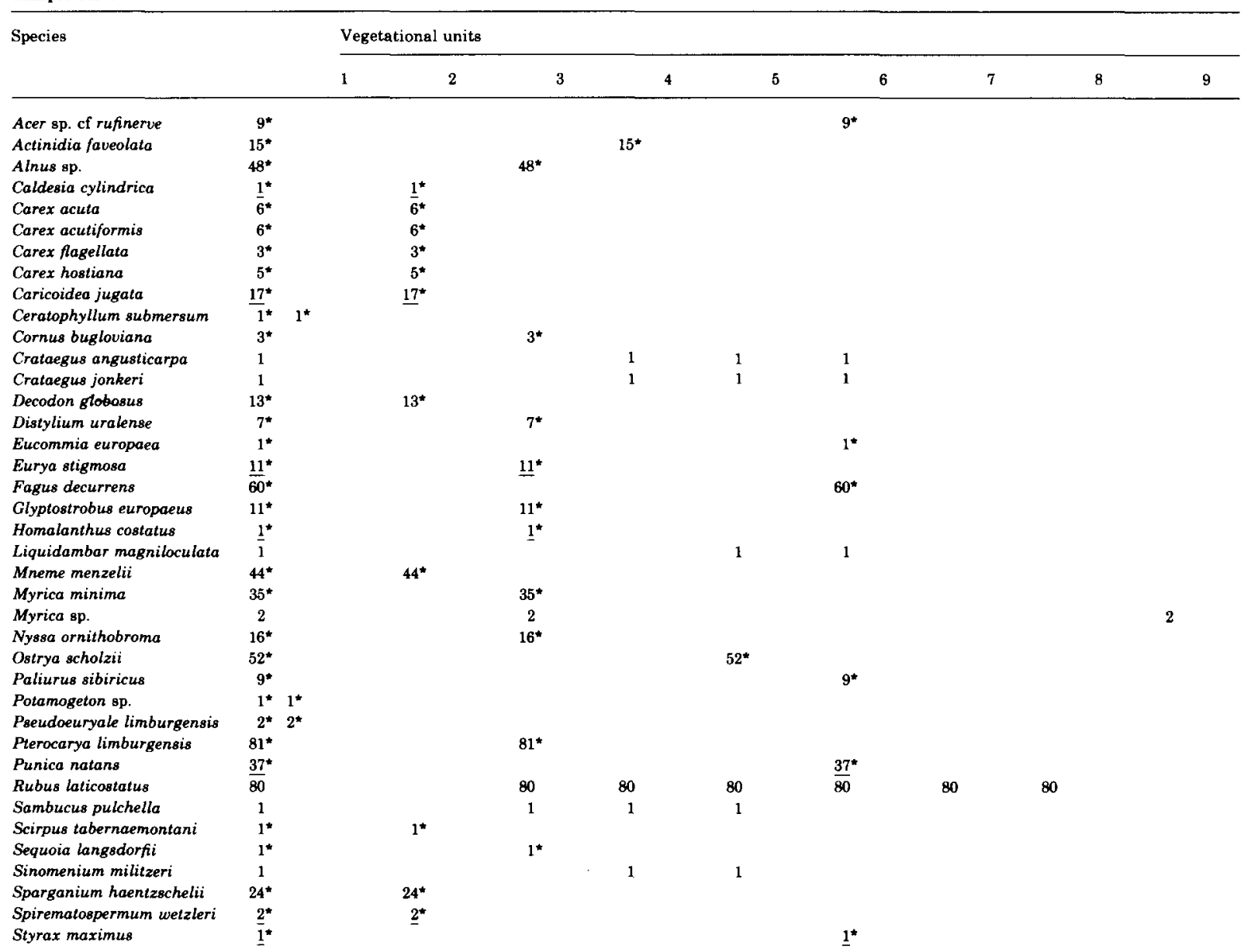


Sample 14141 (continued)

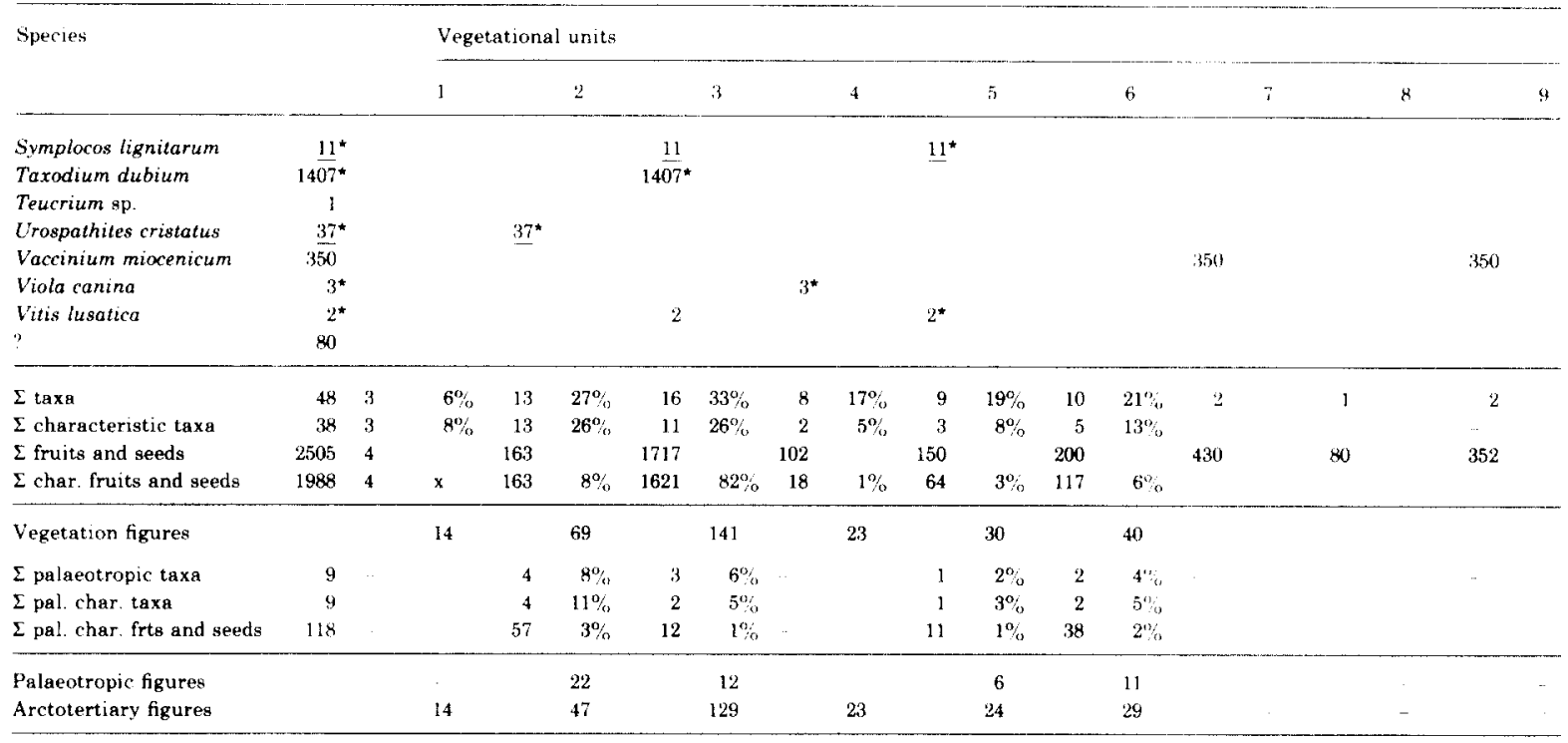

\section{Sample 14142}

Species

Vegetational units

$\begin{array}{lllllllll}1 & 2 & 3 & 4 & 5 & 6 & 7 & 9 & 9\end{array}$

Carya vel Juglans
Crataegus angusticarpa
Eurya stigmosa
Fagus decurrens
Halesia crassa
Homalanthus costatus
Laurocarpum sp.3
Liquidambar magniloculata
Magnolia sp.
Myrica minima
Myrica suppanii
Nyssa disseminata
Ostrya scholzii
Pterocarya limburgensis
Sequoia langsdorfii
Sparganium haentzschelii
Staphylea bessarabica
Symplocos gothanii
Symplocos lignitarum
Taxodium dubium
Toddalia rhenana
Trigonobalanus exacantha
Vitis lusatica
Vitis teutonica
Ziziphus striata
?

?

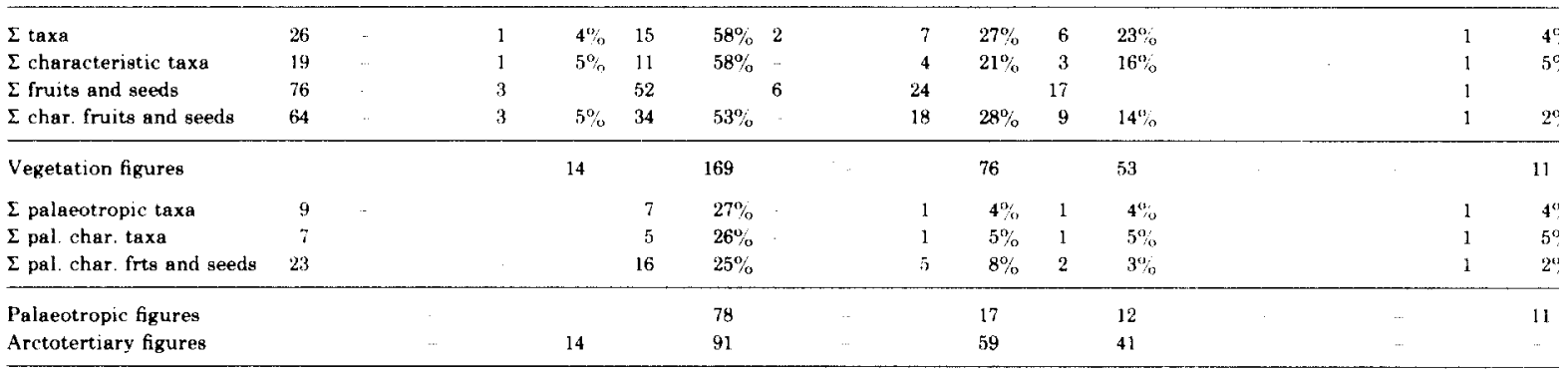


Sample 14143

\begin{tabular}{|c|c|c|c|c|c|c|c|c|c|c|c|c|c|c|c|c|c|c|c|}
\hline \multirow[t]{2}{*}{ Species } & & & \multicolumn{17}{|c|}{ Vegetational units } \\
\hline & & & 1 & & 2 & & 3 & & 4 & & 5 & & 6 & & 7 & & 8 & & 9 \\
\hline Carex acuta & $1^{\star}$ & & & $1^{\star}$ & & & & & & & & & & & & & & & \\
\hline Carex hostiana & $1^{\star}$ & & & $1^{*}$ & & & & & & & & & & & & & & & \\
\hline Carex sp. div. & 2 & & & & & & & & & & & & & & & & & & \\
\hline Caricoidea jugata & $\underline{10}^{*}$ & & & $\underline{10}^{*}$ & & & & & & & & & & & & & & & \\
\hline Cladiocarya europaea & $\underline{\underline{2}}^{*}$ & & & $\overline{2}^{\star}$ & & & & & & & & & & & & & & & \\
\hline Eomastixia persicoides & $\underline{1}^{*}$ & & & & & $\underline{1}^{*}$ & & & & & & & & & & & & & \\
\hline Eurya stigmosa & $\overline{\mathbf{5}}^{*}$ & & & & & $\overline{5}^{\star}$ & & & & & & & & & & & & & \\
\hline Glyptostrobus europaeus & $31^{\star}$ & & & & & $3 \overline{1}^{*}$ & & & & & & & & & & & & & \\
\hline Homalanthus costatus & $\underline{6}^{*}$ & & & & & $\underline{6}^{*}$ & & & & & & & & & & & & & \\
\hline Magnolia burseracea & $\underline{1}^{*}$ & & & & & $\underline{1}^{*}$ & & & & & & & & & & & & & \\
\hline Magnolia lusatica & $\underline{\overline{3}}^{*}$ & & & & & $\underline{\overline{3}}^{*}$ & & & & & & & & & & & & & \\
\hline Mastixia thomsonii & $\underline{11}^{*}$ & & & & & $\underline{1 \overline{1}}$ & & & & $\underline{11} *$ & & & & & & & & & \\
\hline Palliopora symplocoides & $\overline{5}$ & & & & & & & $\underline{\mathbf{5}}$ & & $\underline{\mathbf{5}}$ & & $\underline{5}$ & & & & & & & \\
\hline Pinaceae & $\overline{4}$ & & & & & 4 & & & & & & $\overline{4}$ & & 4 & & & & 4 & \\
\hline Pinus leitzii & 6 & & & & & 6 & & & & & & & & 6 & & & & 6 & \\
\hline Pinus thomasiana & 3 & & & & & 3 & & & & & & & & 3 & & & & 3 & \\
\hline Sequoia langsdorfii & $104^{\star}$ & & & & & $104^{*}$ & & & & & & & & & & & & & \\
\hline Sphenotheca incurva & $\underline{4}$ & & & & & & & $\underline{4}$ & & $\underline{4}$ & & $\underline{4}$ & & & & & & & \\
\hline Symplocos germanica & $\overline{\mathbf{4}}^{\star}$ & & & & & $\underline{4}^{*}$ & & & & & & & & & & & & & \\
\hline Symplocos lignitarum & $\underline{11 \overline{1}^{\star}}$ & & & & & $\underline{11 \overline{1}}$ & & & & $\underline{111}^{*}$ & & & & & & & & & \\
\hline Symplocos pseudogregaria & $\underline{20} *$ & & & & & $\underline{20}$ & & & & $\underline{20}^{*}$ & & & & & & & & & \\
\hline Symplocos salzhausenensis & $\underline{1}^{*}$ & & & & & $\underline{1}^{*}$ & & & & & & & & & & & & & \\
\hline Symplocos schereri & $\underline{\overline{3}}$ & & & & & & & & & $\underline{\mathbf{3}}$ & & 3 & & & & & & & \\
\hline Tectocarya rhenana & $\underline{\overline{2}}$ & & & & & $\underline{2}$ & & & & $\underline{\overline{2}}$ & & & & & & & & & \\
\hline Tetrastigma lobata & $\overline{\overline{3}}^{*}$ & & & & & $\overline{3}$ & & & & $\overline{3}^{*}$ & & & & & & & & & \\
\hline$?$ & $\overline{3}$ & & & & & & & & & & & & & & & & & & \\
\hline$\Sigma \operatorname{tax} a$ & 26 & - & & 4 & $15 \%$ & 17 & $65 \%$ & 2 & & 8 & $31 \%$ & 4 & & 3 & & - & & 3 & \\
\hline$\Sigma$ characteristic taxa & 17 & - & & 4 & $24 \%$ & 9 & $53 \%$ & - & & 4 & $24 \%$ & - & & - & & - & & - & \\
\hline$\Sigma$ fruits and seeds & 345 & - & & 12 & & 296 & & 9 & & 159 & & 16 & & 13 & & - & & 13 & \\
\hline$\Sigma$ char. fruits and seeds & 315 & - & & 12 & $4 \%$ & 156 & $50 \%$ & - & & 145 & $46 \%$ & - & & - & & - & & - & \\
\hline Vegetation figures & & & - & & 43 & & 168 & & - & & 101 & & - & & - & & - & & - \\
\hline$\Sigma$ palaeotropic taxa & 17 & - & & 2 & $8 \%$ & 11 & $42 \%$ & - & & 8 & $31 \%$ & - & & - & & - & & - & \\
\hline$\Sigma$ pal. char. taxa & 15 & - & & 2 & $12 \%$ & 7 & $41 \%$ & - & & 4 & $24 \%$ & - & & - & & - & & - & \\
\hline$\Sigma$ pal. char. frts and seeds & 178 & - & & 12 & $4 \%$ & 18 & $6 \%$ & - & & 145 & $46 \%$ & - & & - & & - & & - & \\
\hline Palaeotropic figures & & & - & & 24 & & 89 & & - & & 101 & & - & & - & & - & & - \\
\hline Arctotertiary figures & & & - & & 19 & & 79 & & - & & - & & - & & - & & - & & - \\
\hline
\end{tabular}

\section{Sample 14145}

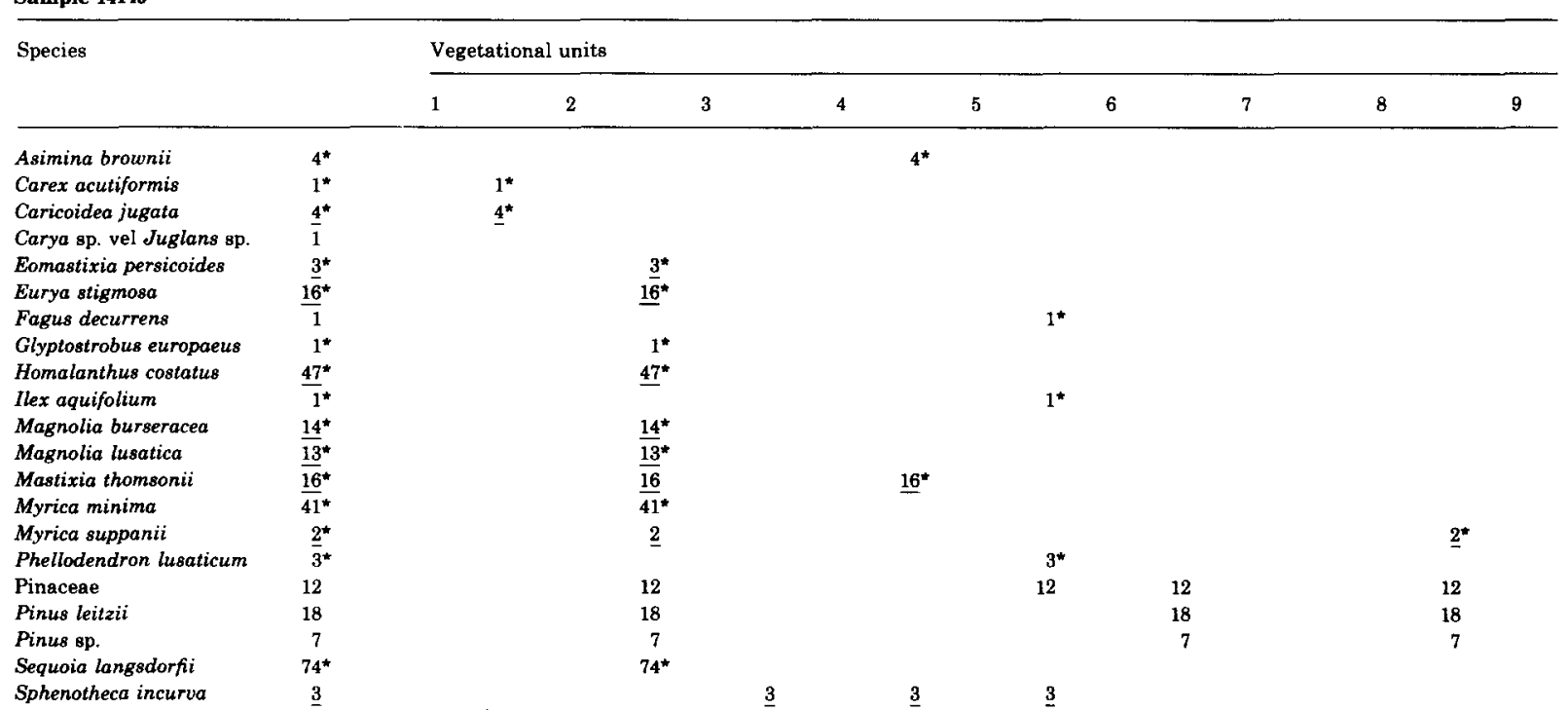


Sample 14145 (continued)

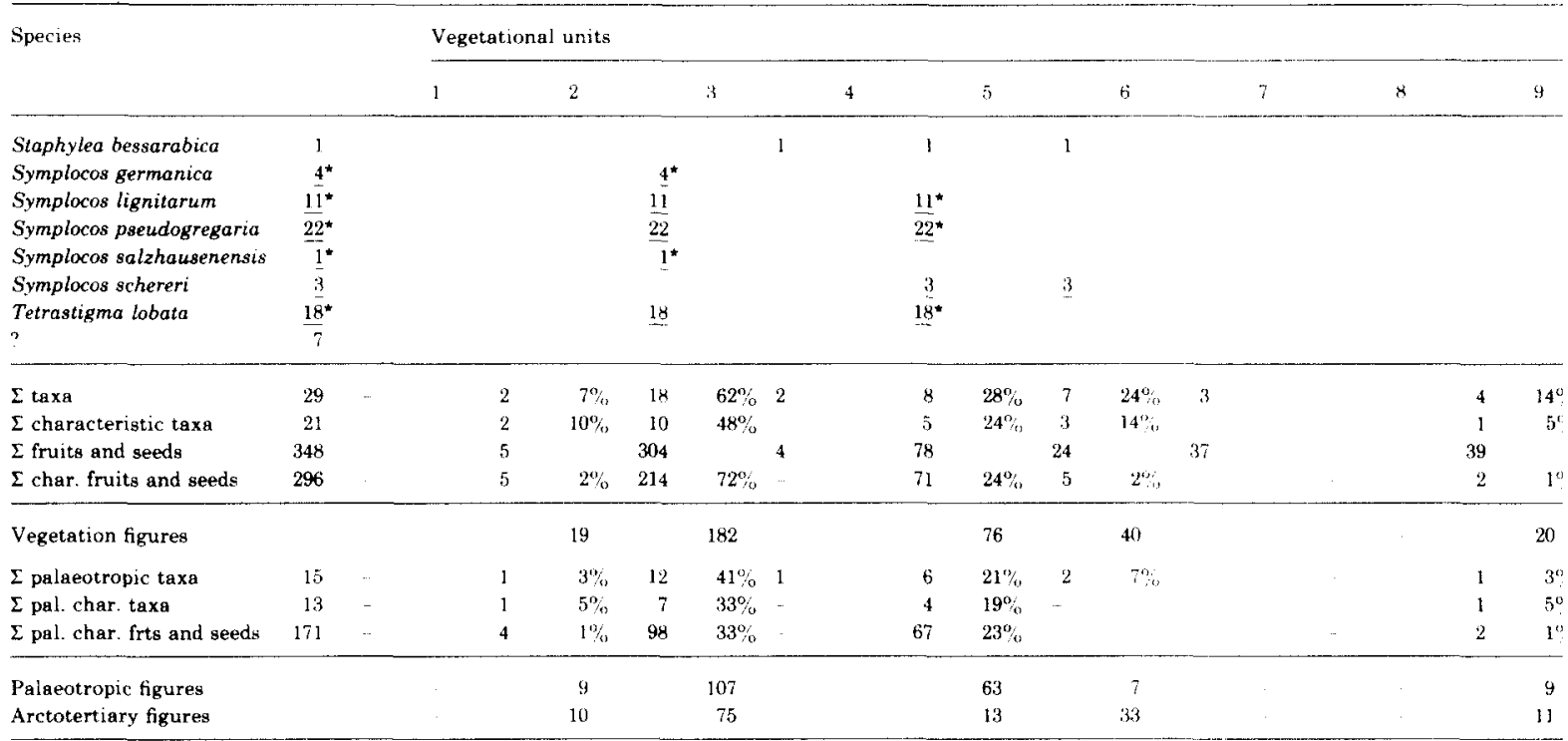

\section{Sample 14146}

\begin{tabular}{|c|c|c|c|c|c|c|c|c|c|c|c|c|c|c|c|c|c|c|c|}
\hline \multirow[t]{2}{*}{ Species } & & & \multicolumn{17}{|c|}{ Vegetational units } \\
\hline & & & 1 & & 2 & & 3 & & 4 & & 5 & & 6 & & 7 & & 8 & & 9 \\
\hline Acanthopanax solutus & $\underline{1}^{*}$ & & & & & & & & & & & $1^{*}$ & & & & & & & \\
\hline Carex sp. div. & $\overline{1}$ & & & & & & & & & & & & & & & & & & \\
\hline Caricoidea jugata & $\underline{9}^{*}$ & & & $g^{*}$ & & & & & & & & & & & & & & & \\
\hline Empetrum nigrum & $\overline{1}^{*}$ & & & & & 1 & & & & & & & & & & & & $1^{\star}$ & \\
\hline Eomastixia persicoides & $2^{*}$ & & & & & $2^{\star}$ & & & & & & & & & & & & & \\
\hline Eurya stigmosa & $\underline{23}^{*}$ & & & & & $23^{*}$ & & & & & & & & & & & & & \\
\hline Glyptostrabus europaeus & $82^{\star}$ & & & & & $82^{\star}$ & & & & & & & & & & & & & \\
\hline Homalenthus costatus & $\underline{5}^{*}$ & & & & & $5^{*}$ & & & & & & & & & & & & & \\
\hline Ilex protogaea & $i^{*}$ & & & & & $1^{\star}$ & & & & & & & & & & & & & \\
\hline Magnolia burseracea & $\underline{1}^{*}$ & & & & & $1^{*}$ & & & & & & & & & & & & & \\
\hline Myrica minima & $2^{\star}$ & & & & & 2 & & & & & & & & & & & & & \\
\hline Nyssa disseminata & $1^{*}$ & & & & & $1^{*}$ & & & & & & & & & & & & & \\
\hline Palliopora symplocoides & $\underline{1}$ & & & & & & & $\underline{1}$ & & 1 & & $\underline{1}$ & & & & & & & \\
\hline Pinaceae & $\overline{1}$ & & & & & 1 & & & & & & $\overline{1}$ & & 1 & & & & 1 & \\
\hline Rubus laticostatus & 11 & & & & & 11 & & 11 & & 11 & & 11 & & 11 & & 11 & & & \\
\hline Sequoia langsdorfii & $181^{\star}$ & & & & & $181^{\star}$ & & & & & & & & & & & & & \\
\hline Symplocos germanica & $\underline{9}^{*}$ & & & & & $9^{\star}$ & & & & & & & & & & & & & \\
\hline Symplocos lignitarum & $269^{*}$ & & & & & $\underline{26 \overrightarrow{9}}$ & & & & $\underline{269^{*}}$ & & & & & & & & & \\
\hline Symplocos pseudogregaria & $73^{\star}$ & & & & & 73 & & & & $\overline{73}^{*}$ & & & & & & & & & \\
\hline Symplocos salzhausenensis & $\overline{4}^{\star}$ & & & & & $4^{*}$ & & & & & & & & & & & & & \\
\hline Symplocos schereri & $\underline{3}$ & & & & & & & & & 3 & & $\underline{3}$ & & & & & & & \\
\hline Tetrastigma lobata & $2 \underline{9}^{*}$ & & & & & $\underline{29}$ & & & & $29^{*}$ & & & & & & & & & \\
\hline$?$ & 7 & & & & & & & & & & & & & & & & & & \\
\hline$\sum \operatorname{taxa}$ & 23 & - & & 1 & $4 \%$ & 17 & $74 \%$ & 2 & & 6 & $26 \%$ & 4 & $22 \%$ & 2 & & 1 & & 2 & $7^{\circ}$ \\
\hline$\Sigma$ characteristic taxa & 17 & & & 1 & $6 \%$ & 11 & $65 \%$ & & & 3 & $18 \%$ & 1 & $6 \%$ & & & .. & & 1 & $6^{\circ}$ \\
\hline$\Sigma$ fruits and seeds & 717 & & & 9 & & 695 & & 12 & & 386 & & 17 & & 12 & & 11 & & 2 & \\
\hline$\Sigma$ char fruits and seeds & 693 & - & & 9 & $1 \%$ & 311 & $45 \%$ & - & & 371 & $54 \%$ & 1 & $\mathrm{x}$ & & & -. & & 1 & $\mathrm{x}$ \\
\hline Vegetation figures & & & & & 11 & & 184 & & & & 98 & & 28 & & & & & & 13 \\
\hline$\Sigma$ palaeotropic tax $a$ & 13 & & & 1 & $4 \%$ & 9 & $39 \%$ & 1 & & 5 & $22 \%$ & 3 & $13 \%$ & & & & & & \\
\hline I pal. char. taxa & 11 & - & & 1 & $6 \%$ & 6 & $35 \%$ & & & 3 & $18 \%$ & 1 & $6 \%$ & & & - & & - & \\
\hline$\Sigma$ pal. char. frts and seeds & 425 & & & 9 & $1 \%$ & 44 & $6 \%$ & & & 371 & $54 \%$ & 1 & $\mathrm{x}$ & & & & & & \\
\hline Palaeotropic figures & & & - & & 11 & & 80 & & & & 94 & & 19 & & & & $\cdots$ & & \\
\hline Arctotertiary figures & & & -- & & & & 104 & & & & 4 & & 9 & & & & & & 13 \\
\hline
\end{tabular}


Sample 1418

\begin{tabular}{|c|c|c|c|c|c|c|c|c|c|c|c|c|c|c|c|c|c|c|c|}
\hline \multirow[t]{2}{*}{ Species } & & & \multicolumn{17}{|c|}{ Vegetational units } \\
\hline & & & 1 & & 2 & & 3 & & 4 & & 5 & & 6 & & 7 & & 8 & & 9 \\
\hline Acer campestre & 1 & & & & & & & 1 & & 1 & & & & & & & & & \\
\hline Actinidia faveolata & $2^{*}$ & & & & & & & $2^{\star}$ & & & & & & & & & & & \\
\hline Ajuga antiqua & $2^{\star}$ & & & & & & & & & $2^{\star}$ & & & & & & & & & \\
\hline Alisma plantago-aquatica & $1^{*}$ & & & $1^{\star}$ & & & & & & & & & & & & & & & \\
\hline Alnus sp. & $5^{*}$ & & & & & $5^{*}$ & & & & & & & & & & & & & \\
\hline Betula sp. & 7 & & & & & 7 & & 7 & & 7 & & 7 & & 7 & & & & & \\
\hline Caldesia cylindrica & $1 *$ & & & $1 *$ & & & & & & & & & & & & & & & \\
\hline Carex acuta & $1^{*}$ & & & $1^{*}$ & & & & & & & & & & & & & & & \\
\hline Carex acutiformis & $1^{*}$ & & & $1^{*}$ & & & & & & & & & & & & & & & \\
\hline Carex hostiana & $1^{*}$ & & & $1^{\star}$ & & & & & & & & & & & & & & & \\
\hline Carex sp. div. & 4 & & & & & & & & & & & & & & & & & & \\
\hline Decodon globosus & $5^{*}$ & & & $5^{*}$ & & & & & & & & & & & & & & & \\
\hline Elucommia europaea & $2 *$ & & & & & & & & & & & $2^{*}$ & & & & & & & \\
\hline Eurya stigmosa & $\underline{6}^{*}$ & & & & & $\underline{6}^{*}$ & & & & & & & & & & & & & \\
\hline Fagus decurrens & $17^{*}$ & & & & & & & & & & & $17^{*}$ & & & & & & & \\
\hline Laurocarpum sp.2 & $\underline{1}$ & & & & & & & & & & & & & & & & & & \\
\hline Liriodendron geminatum & $46^{*}$ & & & & & 46 & & & & $46^{*}$ & & & & & & & & & \\
\hline Magnolia burseracea & $\underline{2}^{*}$ & & & & & $\underline{2}^{\star}$ & & & & & & & & & & & & & \\
\hline Ostrya scholzii & $3 \overline{4}^{\star}$ & & & & & & & & & $34^{*}$ & & & & & & & & & \\
\hline Pinaceae & 3 & & & & & 3 & & & & & & 3 & & 3 & & & & 3 & \\
\hline Pinus sp. & 4 & & & & & 4 & & & & & & & & 4 & & & & 4 & \\
\hline Polyspora lignitica & $\underline{1}^{*}$ & & & & & & & & & $1^{*}$ & & & & & & & & & \\
\hline Potamogeton sp. & $1^{*}$ & $1^{\star}$ & & & & & & & & & & & & & & & & & \\
\hline Pterocarya limburgensis & $6^{*}$ & & & & & $6^{*}$ & & & & & & & & & & & & & \\
\hline Rubus laticostatus & 8 & & & & & 8 & & 8 & & 8 & & 8 & & 8 & & 8 & & & \\
\hline Sambucus pulchella & 9 & & & & & 9 & & 9 & & 9 & & & & & & & & & \\
\hline Sequoia langsdorfii & $6^{*}$ & & & & & $6^{*}$ & & & & & & & & & & & & & \\
\hline Sinomenium militzeri & 1 & & & & & & & 1 & & 1 & & & & & & & & & \\
\hline Solanum nigrum & $3^{*}$ & & & $3^{*}$ & & & & & & & & & & & & & & & \\
\hline Sparganium haentzschelii & $1^{*}$ & & & $1^{*}$ & & & & & & & & & & & & & & & \\
\hline Staphylea sp. & 1 & & & & & & & 1 & & 1 & & 1 & & & & & & & \\
\hline Styrax maximus & $\underline{1}^{*}$ & & & & & & & & & & & $1^{*}$ & & & & & & & \\
\hline Taxodium dubium & $42^{\star}$ & & & & & $42^{*}$ & & & & & & & & & & & & & \\
\hline Umbelliferopsis molassicus & $1^{*}$ & & & $1 *$ & & & & & & & & & & & & & & & \\
\hline Viola canina & $7^{\star}$ & & & & & & & $7 *$ & & & & & & & & & & & \\
\hline Viola rupestris & $5^{*}$ & & & & & & & & & & & & & $5^{*}$ & & & & & \\
\hline Vitis lusatica & $3^{*}$ & & & & & 3 & & & & $3^{\star}$ & & & & & & & & & \\
\hline$?$ & 60 & & & & & & & & & & & & & & & & & & \\
\hline$\Sigma$ taxa & 38 & 1 & $3 \%$ & 9 & $24 \%$ & 13 & $34 \%$ & 8 & $21 \%$ & 11 & $29 \%$ & 7 & $18 \%$ & 5 & $13 \%$ & 1 & & 2 & \\
\hline$\Sigma$ characteristic taxa & 27 & 1 & $4 \%$ & 9 & $33 \%$ & 6 & $22 \%$ & 2 & $7 \%$ & 5 & $19 \%$ & 3 & $11 \%$ & 1 & $4 \%$ & - & & - & \\
\hline$\Sigma$ fruits and seeds & 302 & 1 & & 15 & & 147 & & 36 & & 113 & & 43 & & 27 & & 8 & & 7 & \\
\hline$\Sigma$ char fruits and seeds & 203 & 1 & $\mathbf{x}$ & 15 & $7 \%$ & 67 & $33 \%$ & 9 & $4 \%$ & 86 & $42 \%$ & 20 & $10 \%$ & 5 & $2 \%$ & - & & - & \\
\hline Vegetation figures & & & 7 & & 64 & & 89 & & 32 & & 90 & & 19 & & 19 & & - & & - \\
\hline$\Sigma$ palaeotropic taxa & 6 & - & & 1 & $3 \%$ & 2 & $5 \%$ & - & & 1 & $3 \%$ & 1 & $3 \%$ & - & & - & & - & \\
\hline$\Sigma$ pal. char. taxa & 5 & .. & & 1 & $4 \%$ & 2 & $7 \%$ & - & & 1 & $4 \%$ & 1 & $4 \%$ & - & & - & & & \\
\hline$\Sigma$ pal. char. frts and seeds & 11 & - & & 1 & $\mathbf{x}$ & 8 & $4 \%$ & - & & 1 & $\mathbf{x}$ & 1 & $x$ & - & & - & & - & \\
\hline Palaeotropic figures & & & - & & 7 & & 16 & & - & & 7 & & 7 & & - & & - & & - \\
\hline Arctotertiary figures & & & 7 & & 57 & & 73 & & 32 & & 83 & & 32 & & 19 & & - & & - \\
\hline
\end{tabular}

Sample 14428

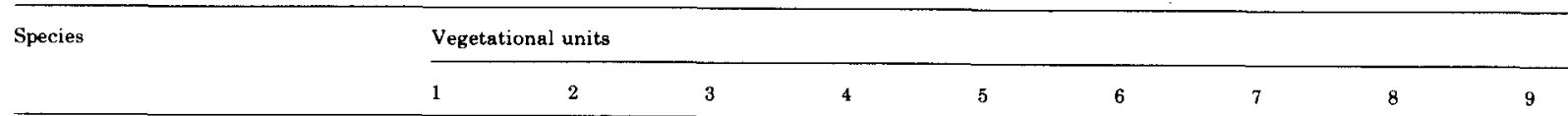

\begin{tabular}{|c|c|c|c|}
\hline Alisma plantago-aquatica & $1^{*}$ & & $1^{*}$ \\
\hline Alnus sp. & $5^{*}$ & & \\
\hline Carpinus betulus & $1^{*}$ & & \\
\hline Ceratophyllum submersum & $2 *$ & $2 *$ & \\
\hline Decodon globosus & $66^{*}$ & & $66^{*}$ \\
\hline Dulichium spathaceum & $1^{*}$ & & $1^{*}$ \\
\hline Magnolia burseracea & $\underline{2}^{\star}$ & & \\
\hline Myrica suppanii & $\underline{\mathbf{1}}^{*}$ & & \\
\hline Nymphaea alba & $\overline{3}^{*}$ & $3^{*}$ & \\
\hline
\end{tabular}

\section{1 *}


Sample 14428 (continued)

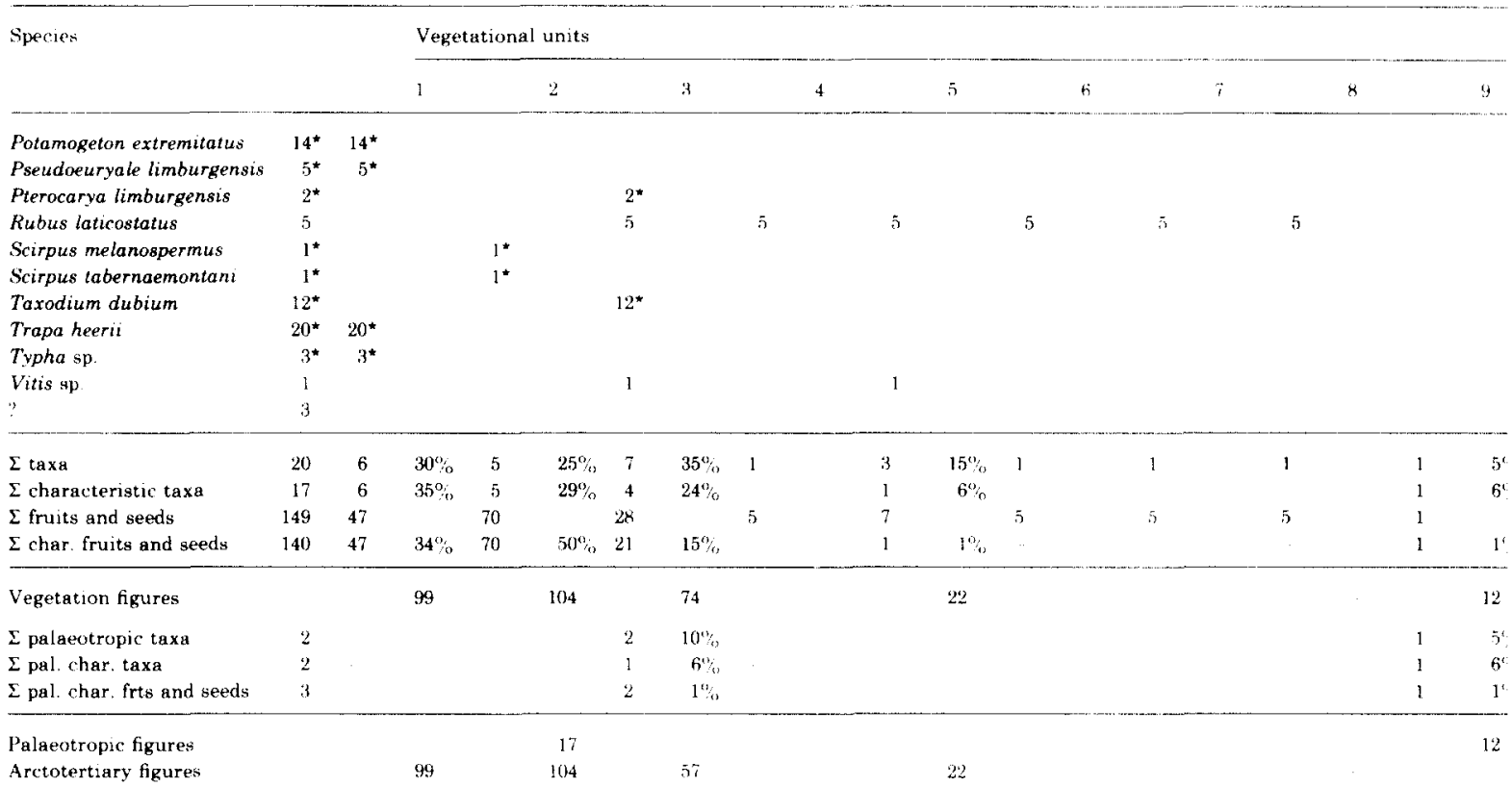

\section{Sample 14429}

Species

Vegetational units

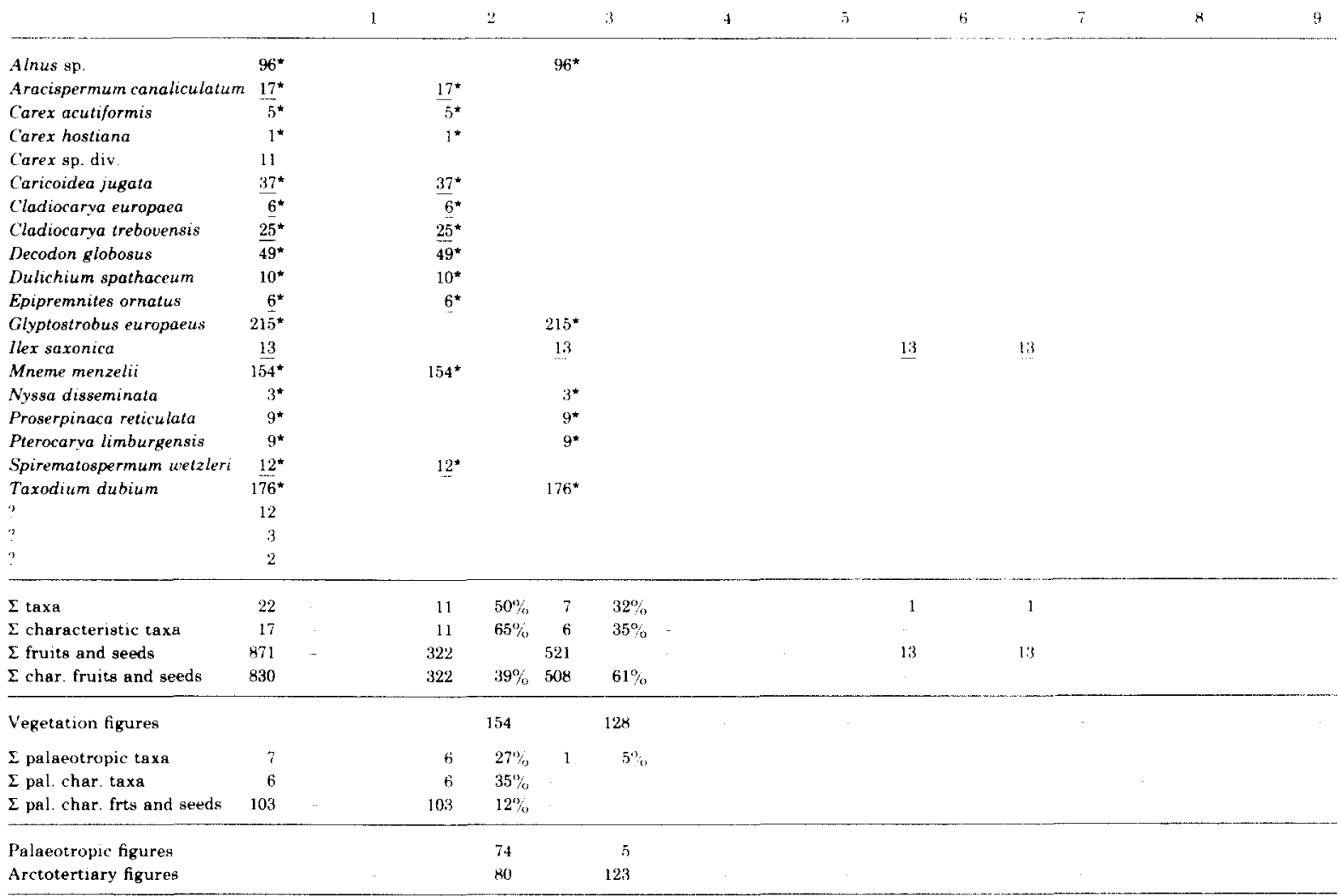




\section{References}

Chandler, M.E.J., 1960. Plant remains of the Hengistbury and Barton beds. Bull. Br. Mus. (Nat. Hist.), 4: 193-238.

Czeczott, H. and Skirgiello, A., 1959. The fossil flora of Turow near Bogatynia. Pr. Muz. Ziemi, 3: 1-128.

Dorofeev, P.I., 1963. Tertiary Floras of Western Siberia. Akad. Nauk. SSSR, Bot. Inst. Komarov, Leningrad, 287 pp. (in Russian).

Dorofeev, P.I., 1972. On the taxonomy of the ancestral forms of Euryale. Bot. Zh., 57: 1047-1054 (in Russian).

Friis, E.M., 1985. Angiosperm fruits and seeds from the Middle Miocene of Jutland (Denmark). The Royal Danish Acad. of Sciences and Letters, Biol. Skrifter, 24, 3: 1-102.

Gregor, H.J., 1977. Subtropische Elemente im europäischen Tertiär II, (Fruktifikationen). Paläontol. Z., 51: 199-226.

Gregor, H.J., 1978a. Die Miozänen Frucht und Samenfloren der Oberpfälzer Braunkohle, I. Funde aus den sandigen Zwischenmitteln. Palaeontographica, B, 167: 8-103.

Gregor, H.I., 1978b. Subtropische Elemente im europäischen Tertiär, III. Rutaceae. Die Gattungen Toddalia und Zanthoxylum. Acta Palaeobot. Cracov, 19: 21-40.

Gregor, H.J., 1980. Die Miozänen Frucht und Samenfloren der Oberpfälzer Braunkohle II Funde aus den Kohlen und tonigen Zwischenmitteln. Palaeontographica, B, 174: 7-94.

Gregor, H.J., 1982. Die Jungtertiären Floren Süddeutschlands. Enke, Stuttgart, $278 \mathrm{pp}$.

Gregor, H.J., 1983. A lower Miocene fruit- and seedflora from the browncoal of Aliveri (Island of Evia, Greece). Documenta naturae, 6: 1-26.

Gregor, H.J., 1984. Subtropische Elemente im europäischen Tertiär IV. Doc. Nat., 16: 1-37.

Gregor, H.J. and Bogner, J., 1984. Fossile Araceen Mitteleuropas und ihre rezenten Vergleichsformen. Doc. Nat., 19: 1-12.

Kilpper, K., 1968a. Koniferen aus den tertiären Deckschichten des Niederrheinischen Hauptflözes, 2. Genus Pinus L. Palaeontographica, B, 123: 213-227.

Kilpper, K., 1968b. Koniferen aus der tertiären Deckschichten des Niederrheinischen Hauptflözes, 3. Taxodiaceae und Cupressaceae. Palaeontographica, B, 124: $102-111$.

Kirchheimer, F., 1934a. Bau und botanische Zugehörigkeit der Datteln aus der Braunkohle des Niederrheins und der Niederlausitz. Braunkohle, 33: 617-618.

Kirchheimer, F., 1934b. Neue Ergebnisse und Probleme paläobotanischer Braunkohlenforschungen. Braunkohle, 33: 769-774 and 788-793.

Kirchheimer, F., 1936. Uber die Pflanzenresten in den Begleitschichten der Braunkohle von Düren. Palaeontol. Z., 18: 213-227.

Kirchheimer, F., 1938. Beiträge zur näheren Kenntnis der Mastixioideenflora des deutschen Mittel bis Oberoligozäns. Beih. Bot. Centralbl., B, 58: 303-375.

Kirchheimer, F., 1940. Ein neuer Beitrag zur Kenntnis der Frucht- und Samenfossilien aus den Braunkohlen- schichten Sachsens und Thüringens. Botan. Arch., 41: 276-294.

Kirchheimer, F., 1941. Ein neuer Beitrag zur Kenntnis der Braunkohlenflora in der Lausitz. Beitr. Biol. Pflanz., 27: 189-231.

Kirchheimer, F., 1943. Bemerkenswerte Frucht- und Samenreste, besonders aus den Braunkohlenschichten. Bot. Arch., 44: 362-430.

Kirchheimer, F., 1949. Die Symplocaceen der erdgeschichtlichen Vergangenheit. Palaeontographica, B, 90: 1-52.

Lancucka-Srodoniowa, M., 1979. Macroscopic plant remains from the freshwater Miocene of the Nowy Sacz Basin (West Carpathians, Poland). Acta Palaeobot. Cracov, 20: 3-117.

Mädler, K., 1939. Die Pliozäne Flora von Frankfurt am Main. Abh. Senckenb. Naturforsch. Ges., 446: 1-202.

Mai, D.H., 1964. Die Mastixioideen Floren im Tertiär der Oberlausitz. Paläontol. Abh. Berl., B, 2: 1-192.

Mai, D.H., 1965. Eine Pliozäne Flora von Kranichfeld in Thüringen. Mitt. Zentr. Geol. Inst., 1: 37-64.

Mai, D.H., 1967. Die Florenzonen, der Florenwechsel und die Vorstellungen über dem Klimaablauf im Jungtertiär der Deutschen Demokratischen Republik. Abh. Zentr. Geol. Inst., 10: 55-81.

Mai, D.H., 1970a. Die tertiären Arten von Trigonobalanus Forman (Fagaceae) in Europe. Jahrb. Geol., 3: 381-409.

Mai, D.H., 1970b. Neue Arten aus Tertiären Lorbeerwaldern. Feddes Repert., 81: 347-370.

Mai, D.H., 1970c. Subtropische Elemente im Europäischen Tertiar. Paläontol. Abh. Berl., B, 3: 441-503.

Mai, D.H., 1971. Uber fossile Lauraceae und Theaceae im Mitteleuropa. Feddes Repert., 82: 313-341.

Mai, D.H., 1973. Die Revision der Originale von R. Ludwig 1857, - Ein Beitrag zur Flora des unteren Villafranchien. Acta Palaeobot. Cracov, 14: 89-117.

Mai, D.H., 1981. Der Formenkreis der Vietnam-Nuss (Carya poilanei (Chev) Leroy) in Europa. Feddes Repert., 92: 339-385.

Mai, D.H., 1983. Studien an Endokarpien europäischer und westasiatischer Arten der Gattung Acer L. (Aceraceae). Gleditschia, 10: 37-57.

Mai, D.H., 1984. Die Endokarpien bei der Gattung Acer L. (Aceraceae) - Eine biosystematische Studie. Gleditschia, 11: 17-46.

Mai, D.H. and Gregor, H.J., 1982. Neue und interessante Arten aus dem Miozän von Salzhausen im Vogelsberg. Feddes Repert., 93: 405-435.

Mai, D.H. and Walther, H., 1978. Die Floren der Haselbachserie im Weisselster Becken (Bezirk Leipzig, DDR). Abh. Staatl. Mus. Min. Geol. Dresden, 28: 1-200.

Monk, C.D., 1966. An ecological significance in evergreenness. Ecology, 47: 504-505.

Negru, A.G., 1968. Fossil fruits of Ruppiaceae and Potamogetonaceae from the Buglovian deposits of Moldavia. Bot. Zh., 9: 1300-1304.

Negru, A.G., 1972. Early Sarmatic Flora from northeast Moldavia. Akad. Nauk. SSSR, Kishinev, 169 pp (in Russian).

Reid, C. and Reid, E.M., 1907. The fossil flora of Tegelen 
sur Meuse, near Venlo, in the province of Limburg Verh. Kon. Akad. Wet., $2^{\mathrm{e}}$ Sectie, 13(6): 1-26.

Reid, C. and Reid, E.M., 1914. A new fossil Corema. J. Bot., 52: 113-114.

Reid, C. and Reid, E.M., 1915. The Pliocene floras of the dutch-prussian border. Meded. Rijksopsporing Delfstoffen, $6: 1-78$.

Reid, E.M., 1923. Nouvelles rècherchges sur les graines du Pliocène inférieur du Pont-de-Gail (Cantal). Bull. Soc. Géol. Fr., 23: 308-355.

Schloemer-Jäger, A., 1960. Koniferenzapfen aus der Niederrheinischen Braunkohle. Senckenbergiana Lethaea, 41: $209-253$.

Thomson, P.W., 1954. Asimina browni sp. n., Braunkohle, 6: $314-315$.

Truchanowiczowa, J., 1964. Fossil seeds of the genus
Menyanthes in Eurasia. Acta Palaeobot. Cracov., 5 $25-53$.

Van der Burgh, J., 1964. Hölzer der Niederrheinischen Braunkohlenformation. I. Acta Bot. Neerl., 13: 250-301.

Van der Burgh, J., 1973. Hölzer der Niederrheinischen Braunkohlenformation. II. Rev. Palaeobot. Palynol., 15 73-275.

Van der Burgh, J., 1978. The Pliocene flora of Fortuna Garsdorf, I Fruits and seeds of Angiosperms. Rev Palaeobot. Palynol., 26: 173-211.

Van der Burgh, J., 1983. Allochthonous seed and fruit floras from the Pliocene of the lower Rhine basin. Rev. Palaeobot. Palynol., 40: 33-90.

Van der Burgh, J., in press. Some local floras from the Neogene of the lower Rhenish basin. Tertiary Research special paper. 